\title{
On the Lomechusini fauna of the Palaearctic and Oriental regions. XXVI. New species, a new synonymy, and additional records (Coleoptera: Staphylinidae: Aleocharinae)
}

\author{
With 169 figures and 1 map
}

VOLKER ASSING ${ }^{1}$

\author{
${ }^{1}$ Gabelsbergerstraße 2, 30163 Hannover, Germany. - vassing.hann@t-online.de \\ Published on 2019-06-24 \\ DOI:10.21248/contrib.entomol.69.1.033-070
}

\begin{abstract}
Abstact
Types and additional material of twelve genera of Lomechusini from the Palaearctic and Oriental regions are revised. In all, 24 species are described and/or illustrated, 21 of them new: Pella feldmanni spec. nov. (China: Sichuan) of the P. cognata group; Orphnebius fortesetosus spec. nov. (China: Sichuan) and O. taurus spec. nov. (Cambodia) of the O. hauseri group; Orphnebius (Deroleptus) morulus spec. nov. (South Vietnam), O. (D.) globulifer spec. nov. (Malaysia: Pahang), O. (D.) elevatus spec. nov. (Laos), and O. (D.) moruliflavus spec. nov. (Malaysia: Sabah) of the O. siwalikensis group; Keratodegnathus cornutus spec. nov. (Malaysia: Pahang); Amaurodera schmidti spec. nov. (East Nepal) of the A. silvana group; A. brevipennis spec. nov. (Malaysia: Sabah); A. atra spec. nov. (Philippines: Mindanao); Drusilla bispinosa spec. nov. (Malaysia: Pahang); D. shavrini spec. nov. (Philippines: Mindanao); D. penicillata spec. nov. (Philippines: Mindanao); D. spiniventris spec. nov. (Philippines: Mindanao); D. breviuter spec. nov. (Philippines: Mindanao); Pheidologitonetes biplicatus spec. nov. (China: Yunnan); Zyras (Zyras) conlectus spec. nov. (Myanmar); Z. (Z.) hetzeli spec. nov. (Taiwan); Z. (Z.) reductus spec. nov. (Philippines: Mindanao); Z. (Z.) shavrini spec. nov. (Philippines: Mindanao). The following synonymy is established: Drusilla obliqua (Bernhauer, 1916) $=$ D. $z y$ rasoides Dvořák, 1988, syn. nov. Additional records of 49 named species are reported, among them twelve first records from Greece (1), Lebanon (1), Israel (1), Jordan (1), Iran (1), Nepal (1), China (1), Taiwan (1), Laos (1), Cambodia (2), and Borneo (1). The distribution of Myrmoecia urartu (IABLOKOFF-KHnZorian, 1962) is mapped.
\end{abstract}

\section{Taxonomic acts}

Pella feldmanni spec. nov. - urn:lsid:zoobank.org:act:E98B0247-7020-4845-B7B3-7FB5946DCA24 Orphnebius fortesetosus spec. nov. - urn:lsid:zoobank.org:act:CEE40705-FCE7-47A3-859A-614E2D7ADCAC Orphnebius taurus spec. nov. - urn:lsid:zoobank.org:act:9C47DCE3-7D9A-4D71-8A4B-24036B41A66D Orphnebius morulus spec. nov. - urn:Isid:zoobank.org:act:DF080E64-CDBB-4BE4-A7CF-D71EA3A270AC Orphnebius globulifer spec. nov. - urn:lsid:zoobank.org:act:F2AB5418-A6A3-4125-AB1B-5B6C18EEF85E Orphnebius elevatus spec. nov. - urn:lsid:zoobank.org:act:839D7EBF-6AD4-420B-97A1-8448D1F5036B Orphnebius moruliflavus spec. nov. - urn:Isid:zoobank.org:act:57A6C5B3-7F8A-46BB-88B3-2213C17C91A8 Keratodegnathus cornutus spec. nov. - urn:lsid:zoobank.org:act:042656C4-9410-4A3A-9648-037977E13C0C Amaurodera schmidti spec. nov. - urn:lsid:zoobank.org:act:7ABC3A7D-5EA4-47C5-90A5-F8F451BF1914 Amaurodera brevipennis spec. nov. - urn:lsid:zoobank.org:act:5AB88702-0D52-4B1F-A7AA-0654B71DC14F Amaurodera atra spec. nov. - urn:lsid:zoobank.org:act:7D5CCE81-D9AF-4599-B7C0-AA4D6D0AD8C2 
Drusilla bispinosa spec. nov. - urn:lsid:zoobank.org:act:A3E4F51F-809D-407F-9DE0-5655A67106AC Drusilla shavrini spec. nov. - urn:lsid:zoobank.org:act:7EF756D2-6CFE-4230-AAF4-298C3D1B76BE Drusilla penicillata spec. nov. - urn:lsid:zoobank.org:act:CAA17FAD-AE2A-496C-9D08-84D34358BDD5 Drusilla spiniventris spec. nov. - urn:lsid:zoobank.org:act:BB6FB0AD-90DC-457E-90A1-0534A8AE43D6 Drusilla breviuter spec. nov. - urn:lsid:zoobank.org:act:43EDA558-1DBF-4861-B73F-F292EF6169C5 Pheidologitonetes biplicatus spec. nov. - urn:lsid:zoobank.org:act:77CC7252-1567-4522-A89E-9B0D5E1C486A Zyras conlectus spec. nov. - urn:lsid:zoobank.org:act:EEF29D05-2E17-4205-805A-B8BFFAE0FE98 Zyras hetzeli spec. nov. - urn:lsid:zoobank.org:act:F00342B5-F2BF-461A-A84A-282D19159065 Zyras reductus spec. nov. - urn:lsid:zoobank.org:act:15761BF9-31AA-4B92-A7A5-8C3535DF876C Zyras shavrini spec. nov. - urn:lsid:zoobank.org:act:A7C7B14F-AA8A-47EB-AA6F-F7A7C2B040A4

\section{Key words}

Palaearctic region, Oriental region, taxonomy, new species, new synonymy, zoogeography, distribution map, additional records

\section{Zusammenfassung}

Typen und weiteres Material von zwölf Gattungen des Tribus Lomechusini aus der Paläarktis und der Orientalis werden revidiert. Insgesamt werden 24 Arten beschrieben und/oder abgebildet, 21 davon neu: Pella feldmanni spec. nov. (China: Sichuan) aus der P. cognata-Gruppe; Orphnebius fortesetosus spec. nov. (China: Sichuan) und O. taurus spec. nov. (Kambodscha) aus der O. hauseri-Gruppe; Orphnebius (Deroleptus) morulus spec. nov. (SüdVietnam), O. (D.) globulifer spec. nov. (Malaysia: Pahang), O. (D.) elevatus spec. nov. (Laos) und O. (D.) moruliflavus spec. nov. (Malaysia: Sabah) aus der O. siwalikensis-Gruppe; Keratodegnathus cornutus spec. nov. (Malaysia: Pahang); Amaurodera schmidti spec. nov. (Ost-Nepal) aus der A. silvana-Gruppe; A. brevipennis spec. nov. (Malaysia: Sabah); A. atra spec. nov. (Philippinen: Mindanao); Drusilla bispinosa spec. nov. (Malaysia: Pahang); D. shavrini spec. nov. (Philippinen: Mindanao); D. penicillata spec. nov. (Philippinen: Mindanao); D. spiniventris spec. nov. (Philippinen: Mindanao); D. breviuter spec. nov. (Philippinen: Mindanao); Pheidologitonetes biplicatus spec. nov. (China: Yunnan); Zyras (Zyras) conlectus spec. nov. (Myanmar); Z. (Z.) hetzeli spec. nov. (Taiwan); Z. (Z.) reductus spec. nov. (Philippinen: Mindanao); Z. (Z.) shavrini spec. nov. (Philippinen: Mindanao). Ein Name wird synonymisiert: Drusilla obliqua $($ Bernhauer, 1916) $=$ D. zyrasoides DvořáK, 1988, syn. nov. Weitere Nachweise von 49 beschriebenen Arten werden gemeldet, darunter zwölf Erstnachweise aus Griechenland (1), Libanon (1), Israel (1), Jordanien (1), Iran (1), Nepal (1), China (1), Taiwan (1), Laos (1), Kambodscha (2) und Borneo. Die derzeit bekannte Verbreitung von Myrmoecia urartu (IABLOKOfF-KhnZorian, 1962) wird anhand einer Karte illustriert.

\section{Schlüsselwörter}

Paläarktis, Orientalis, Taxonomie, neue Arten, neue Synonymie, Zoogeographie, Verbreitungskarte, weitere Nachweise

\section{Introduction}

Less than a decade ago, the mega-diverse polyphyletic tribe Lomechusini included approximately 2200 species worldwide. Numerous additional species have been described in the meantime (see Assing 2017a-c and references cited therein). The Palaearctic and Oriental representatives of some genera have been subject to revisionary work (for an overview see Assing 2016b, 2017a), but the vast majority of taxa has been described in the context of articles dealing with miscellaneous Staphylinidae or Aleocharinae. In consequence, some lomechusine taxa such as Pella Stephens, 1835, West Palaearctic and Middle Asian Drusilla LeAch, 1819, Lomechusa Gravenhorst, 1806, Lomechusoides Tottenham, 1939, Tetrabothrus Bernhauer, 1915
Amaurodera Fauvel, 1905, and Orphnebius MotschulSKY, 1858 can be considered fairly well known, although numerous additional species of Orphnebius will undoubtedly be discovered in the future. The latest full-scale revision is that of Zyras STEPhens, 1835 sensu strictu of the East Palaearctic and Oriental regions (Assing 2016a, 2017b, c). On the other hand, the Oriental fauna of the speciose genus Drusilla, for instance, is very poorly known. Based on personal observations, there is substantial material representing numerous species in various collections examined, but a comprehensive revision has not yet been attempted. The same is true of Zyras species currently assigned to subgenera other than the nominal subgenus. 
The present paper deals with abundant material of Lomechusini that has become available since the latest contribution (Assing 2017a). An examination of this material yielded numerous new records of zoogeographic interest, as well as 21 new species, seven of them from the Philippine island Mindanao.

\section{Material and methods}

The material treated in this study is deposited in the following collections:

IZAY Armenian National Academy of Sciences, Institute of Zoology, Yerevan (M. Kalashian, T. Ghrejyan)

MMB Moravian Museum Brno (P. Baňař)

MNB Museum für Naturkunde Berlin (coll. M. Schülke)

NME Naturkundemuseum Erfurt (M. Hartmann, assisted by W. Apfel)

NMP National Museum of Natural History, Praha (J. Hájek)

SCS Sichuan University Chengdu, China

VNMN Vietnam National Museum of Nature, Hanoi

cAss author's private collection

cAnl private collection Sinan Anlaş, Izmir

cFel private collection Benedikt Feldmann, Münster

cKov private collection Alexey Kovalev, St. Petersburg cRou private collection Guillaume de Rougemont, Oxford

The morphological studies were conducted using a Stemi SV 11 microscope (Zeiss), a Discovery V12 microscope (Zeiss), and a Jenalab compound microscope (Carl Zeiss Jena). The images of the external characters were created using a photographing device constructed by Arved Lompe (Nienburg) and CombineZ software, a digital camera (Nikon Coolpix 995), Axiocam ERc 5s, and Picolay stacking software. The map was created using MapCreator 2.0 (primap) software.

Body length was measured from the anterior margin of the labrum to the apex of the abdomen, the length of the forebody from the anterior margin of the labrum to the posterior margin of the elytra, head length from the anterior margin of the clypeus (without ante-clypeus) to the posterior constriction of the head, the length of the elytra along the suture from the apex of the scutellum to the posterior margin of the elytra, the length of the median lobe of the aedeagus from the apex of the ventral process to the base of the aedeagal capsule (if not noted otherwise), and the length of the spermatheca is given as the maximal extension (measured from the apex of the distal portion of the capsule). The "parameral" side of the median lobe of the aedeagus (i.e., the side where the sperm duct enters) is referred to as the ventral, the opposite side as the dorsal aspect.

\section{Results}

\subsection{Genus Myrmoecia Mulsant \& Rey, 1873}

Myrmoecia is confined to the West Palaearctic region, where it is currently represented by 16 valid species (SchüLKe \& SMetana 2015). The genus has never been subject to a modern revision, and the sexual characters of the vast majority of species is unknown. Thanks to the courtesy of Mark Kalashian (Yerevan), it was possible to clarify the previously doubtful identity of a species described from Armenia.

\section{Myrmoecia urartu (IABLOKOFF-KHnZORIAN, 1962) (Figs 1, 79, Map 1)}

Zyras urartu IABLOKOFF-KHNZORIAN, 1962, $111 \mathrm{f}$.

Type material: Holotype $+:$ "Erevan. 10.4.55, Nor-Aresh, N. N. Akramovski / Typus / Zyras urartu Khnj, Khnzorian det. / Holotype / Myrmoecia urartu (Iablokoff-Khnzorian), det. V. Assing 2018" (IZAY).

Additional material examined: Israel: $1 \%$, Sede Boqer range, $30^{\circ} 51^{\prime} \mathrm{N}, 34^{\circ} 46^{\prime} \mathrm{E}, 500 \mathrm{~m}, 24 . I I .2011$, leg. Drees (cAss); $10^{\prime \prime}$, Upper Galilee, Biriya env., 32 $2^{\circ} 59^{\prime} \mathrm{N}, 35^{\circ} 29^{\prime} \mathrm{E}$, flight trap, 17.V.-4.VI.2007, leg. Buse (cFel); 1 \% , same data, but without date (cFel); $10^{7}$, Upper Galilee, Meron, $33^{\circ} 00^{\prime} \mathrm{N}, 35^{\circ} 26^{\prime} \mathrm{E}$, flight trap, 5-25.VI.2007, leg. Buse (cFel). Jordan: 1 ㅇ, Ma’an, N Wadi Musa, $30^{\circ} 24^{\prime} \mathrm{N}$, $35^{\circ} 30^{\prime} \mathrm{E}, 1670 \mathrm{~m}$, 29.II.2015, leg. Meybohm (cAss). Iran: $10^{7}$, Esfahan Province, $10 \mathrm{~km}$ E Zefreh, Mt. Marshenan, $32^{\circ} 56^{\prime} \mathrm{N}, 52^{\circ} 22^{\prime} \mathrm{E}, 2490 \mathrm{~m}, 16 . \mathrm{V} .2007$, leg. Frisch \& Serri (cAss).

Comment: The original description is based on a unique specimen from Armenia (IABLOKOFF-KhnZORIAN 1962). The holotype is a female and illustrated in Figs 1, 79. The species was originally assigned to Zyras STEPHENs, 1835 and subsequently moved to Myrmoecia by MARUYAMA (2006). The above records represent the first records since the original description and the first records from Israel, Jordan, and Iran. The currently known distribution is illustrated in Map 1.

\subsection{Genus Pella StePhens, 1835}

\section{Pella discolor Assing, 2008}

Material examined: Greece: 1 + , Lesbos, Oros Lepetimnos, $39^{\circ} 20^{\prime} \mathrm{N}, 26^{\circ} 15^{\prime} \mathrm{E}, 800 \mathrm{~m}, 25 . I I I .2016$, leg. Assing \& Hetzel (cAss). Turkey: 1 우, Konya, Seydişehir, Geyik mountains, $37^{\circ} 26^{\prime} \mathrm{E}, 31^{\circ} 43^{\prime} \mathrm{E}, 2000 \mathrm{~m}, 21 . \mathrm{V} .2016$, leg. Anlaş (cAnl); 1 \&, Denizli, Çal, Büyük Çökelez mountains, $1600 \mathrm{~m}, 38^{\circ} 01^{\prime} \mathrm{N}, 29^{\circ} 22^{\prime} \mathrm{E}, 23 . I I I .2016$, leg. Örgel (cAss). 


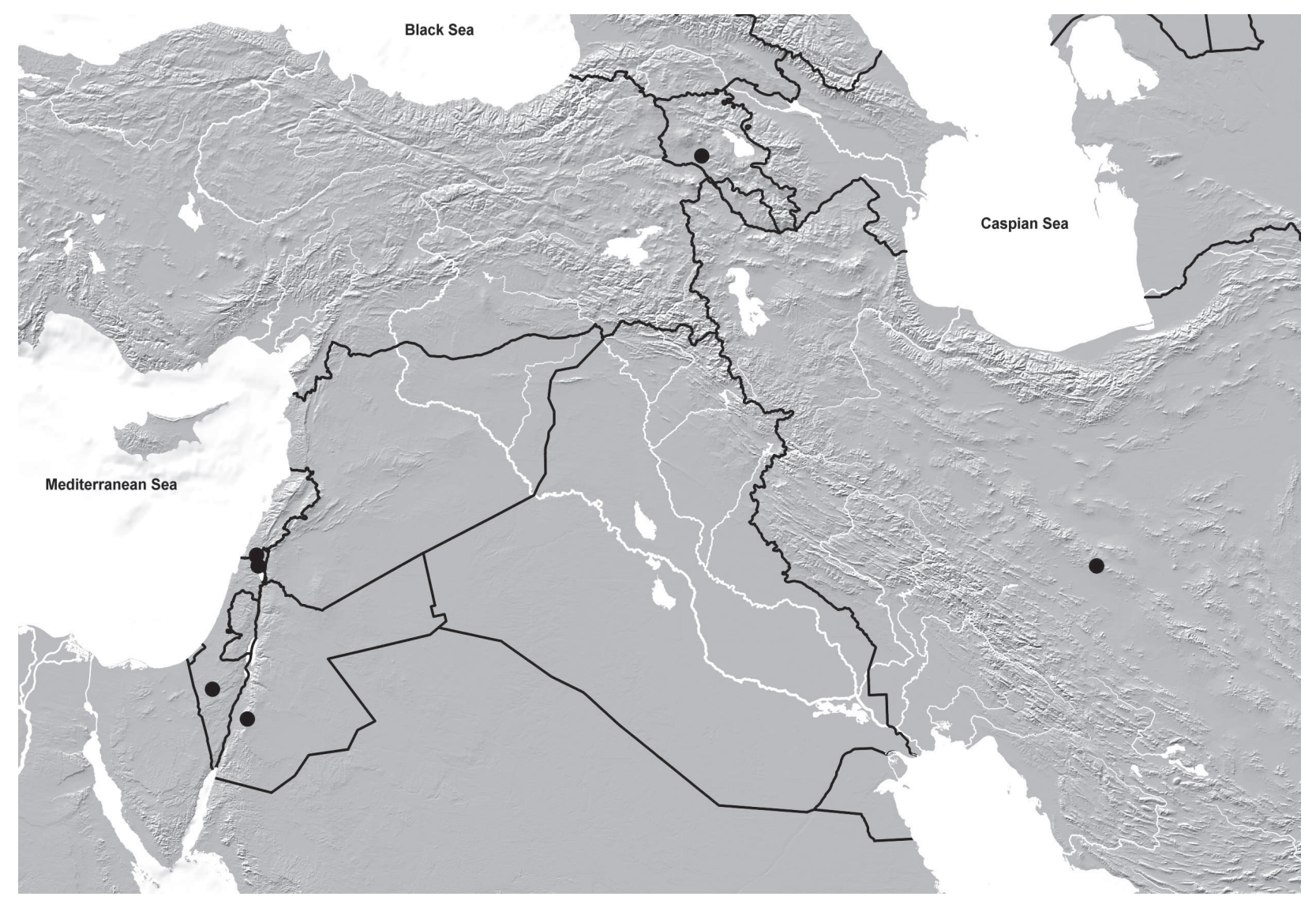

Map 1: Distribution of Myrmoecia urartu.

Comment: This recently described species was previously known from the Turkish provinces Kahramanmaraş, Konya, and Ankara (Assing 2008). The above specimen from the Greek island Lesbos was erroneously recorded as P. cinctipennis (EPPElsheim, 1884) by Assing (2016c).

\section{Pella feldmanni spec. nov.}

urn:Isid:zoobank.org:act:E98B0247-7020-4845-B7B3-7FB5946DCA24 (Figs 2, 80-83)

Type material: Holotype $0^{\text {* }}$ "China, Sichuan, NW Heishui, $3428 \mathrm{~m}, 32^{\circ} 11^{\prime} 29^{\prime \prime} \mathrm{N}, 102^{\circ} 39^{\prime} 30^{\prime} \mathrm{E}, 14-20 . \mathrm{VI}$. 2018, leg. Reuter / Holotypus ơ Pella feldmanni sp. n., det. V. Assing 2018” (cAss).

Etymology: This species is dedicated to Benedikt Feldmann (Münster), who made the holotype available and who generously granted permission to retain it.

Description: Body length $6.7 \mathrm{~mm}$; length of forebody $2.9 \mathrm{~mm}$. Habitus as in Fig. 2. Coloration: head black; pronotum and elytra black with weak metallic hue; abdomen blackish with the posterior margins of the segments reddish; legs dark-reddish with the femora slightly darker; antennae reddish-brown.

Head transverse, 1.25 times as broad as long, with sexual dimorphism; punctation very fine and dense, somewhat sparser in antero-median portion; interstices with distinct microreticulation. Eyes longer than postocular region and moderately convex in cross-section. Antenna barely $2.0 \mathrm{~mm}$ long; antennomeres IV-V moderately transverse, VI approximately 1.5 times as broad as long, VII-X approximately twice as broad as long, and XI longer than the combined length of IX and X, but shorter than the combined length of VIII-X.

Pronotum 1.33 times as broad as long and 1.37 times as broad as head; posterior angles very weakly marked, nearly obsolete; disc with an oblique impression in postero-lateral portion on either side; punctation fine and dense; interstices with shallow microreticulation.

Elytra 0.83 times as long as pronotum; punctation distinctly denser and finer than that of pronotum.

Abdomen nearly as broad as elytra; tergites III-VII nearly impunctate in anterior halves, sparsely punctate in posterior halves, and with numerous fine setiferous punctures at posterior margins; tergal discs with fine microsculpture composed of transverse meshes; posterior margin of tergite VII with palisade fringe.

$0^{\top}$ : head sharply angled posteriorly (best visible in lateral view); posterior margin of tergite VIII broadly concave and finely crenulate (Fig. 82); posterior margin of sternite VIII truncate in the middle (Fig. 83); median lobe of aedeagus (Figs 80-81) $0.88 \mathrm{~mm}$ long; ventral process very thick in lateral view and apically regularly convex in ventral view. 
Comparative notes: Based on the similar external characters and particularly on the similar modifications of the male head and on the morphology of the aedeagus, $P$. feldmanni is closely allied to $P$. cognata MärkeL, 1824 (West Palaearctic), P. puetzi Assing, 2009 (China: Yunnan), and P. maoershanensis SoNG \& LI, 2013 (China: Guangxi) of the P. cognata group, which was previously represented in China by four species: P. puetzi, P. maoershanensis, P. kishimotoi Maruyama, 2006 (China: Hunan), and P. sichuanensis ZHENG \& ZHAO, 2014 (China: Sichuan). The new species is distinguished from them as follows:

from $P$. puetzi by much shorter antennae with much more transverse antennomeres IV-X (P. puetzi: antennomeres IV-VII weakly oblong or as long as broad; VIII-X weakly transverse), less pronounced modifications of the male head, a relatively smaller and more convex (cross-section) pronotum, and a larger aedeagus with a much stouter and differently shaped ventral process;

from P. kishimotoi by uniformly dark coloration (P. kishimotoi: humeral portions of elytra and abdominal segments III-V reddish-brown), the modifications of the male head (unmodified in P. kishimotoi), and the differently shaped ventral process of the aedeagus;

from $P$. sichuanensis by uniformly dark coloration, a transverse antennomere IV, a relatively smaller pronotum, shorter elytra, and an aedeagus with a stouter ventral process in lateral view;

from $P$. maoershanensis by apically more strongly incrassate antennae, a less strongly modified male head, shorter elytra, a posteriorly less broadly concave male tergite VIII, and an aedeagus with a much smaller crista apicalis and with a ventral process of completely different shape.

For illustrations of P. puetzi, P. kishimotoi, P. sichuanensis, and $P$. maoershanensis see Assing (2009), Maruyama (2006), Song \& Li (2013), and Zheng \& ZHAO (2014).

Distribution and natural history: The type locality is situated in North Sichuan, China. The holotype was collected with pitfall traps in a young moist secondary forest at an altitude of approximately $3430 \mathrm{~m}$.

\subsection{Genus Orphnebius Motschulsky, 1858}

This speciose genus was previously represented in the East Palaearctic and Oriental regions by 174 species, many of them of doubtful identity and/or doubtful intrageneric affiliations. When compiling a comprehensive checklist for the previous contribution (Assing 2017a), one species was overlooked: Orphnebius ferrugineus CAMERoN, 1939 from Sri Lanka. Including this species and the six newly described taxa, the Orphnebius fauna of the Palaearctic and Oriental regions now includes 181 species.

\section{Orphnebius cachemiricus ColfFAlt, 1983}

(Figs 84-86)

Material examined: Nepal: $1 \sigma^{*}$, Mahakali/Darchula, Thaisain env., Brum lake, 29 $52^{\prime} \mathrm{N}, 80^{\circ} 41^{\prime} \mathrm{E}, 3600 \mathrm{~m}$, 19-20.VI.2017, leg. Kopetz (NME); $10^{\star}$, Seti Province, Doti District, Khaptad National Park, trail from Tribeni to Jhingrana, $29^{\circ} 22^{\prime} \mathrm{N}, 81^{\circ} 08^{\prime} \mathrm{E}, 3000-2300 \mathrm{~m}$, mixed forest, 3.VII.2009, leg. Weigel (cAss).

The original description of this species is based on a female from Kashmir. The above specimens represent the first records from Nepal. The previously unknown male sexual characters are illustrated in Figs 84-86.

\section{Orphnebius mutabilis Assing, 2006}

Material examined: Nepal: $1 \sigma^{\pi}$, Taplejung, Pathibara W-slope, $27^{\circ} 26^{\prime} \mathrm{N}, 87^{\circ} 47^{\prime} \mathrm{E}, 3000-3400 \mathrm{~m}, 14-15 . V .2016$, leg. Schmidt (NME); $10^{\star}$, Taplejung, Pathibara W-slope, $27^{\circ} 24^{\prime} \mathrm{N}, \quad 87^{\circ} 45^{\prime} \mathrm{E}, \quad 2600-2800 \mathrm{~m}, 18-19$. V.2016, leg. Schmidt (NME); $10^{7}$, Sankhuwa-Sabha, N Chauki, $27^{\circ} 13^{\prime} \mathrm{N}, 87^{\circ} 28^{\prime} \mathrm{E}, 2600-2700 \mathrm{~m}, 27 . \mathrm{V} .2016$, leg. Schmidt (cAss).

The known distribution of O. mutabilis is confined to several localities in Central and East Nepal (Assing 2017a).

\section{Orphnebius jumlaicus Assing, 2006}

Material examined: Nepal: $1 \sigma^{\lambda}$, Mahakali/Darchula, Godhani, Godhani Khola, 29 $50^{\circ} \mathrm{N}, 80^{\circ} 41^{\prime} \mathrm{E}, 1920 \mathrm{~m}$, 16.VI.2017, leg. Kopetz (NME).

The distribution ranges from Pakistan and Kashmir across North India to Nepal (Assing 2017a).

\section{Orphnebius hamatus Assing, 2006}

Material examined: Nepal: 1 \% , Rolwaling Himal, Simigaon, 2700-2800 m, 1.VI.2000, leg. Schmidt (cKle); 1 ㅇ, Annapurna, Lamjung Himal, W Taunja Dada, 5 km NE Sikles, 2200-3000 m, 19.V.1993, leg. Schmidt (cAss).

This species is known only from Nepal. The above females were reported as Orphnebius spec. nov. in Assing (2017a). 

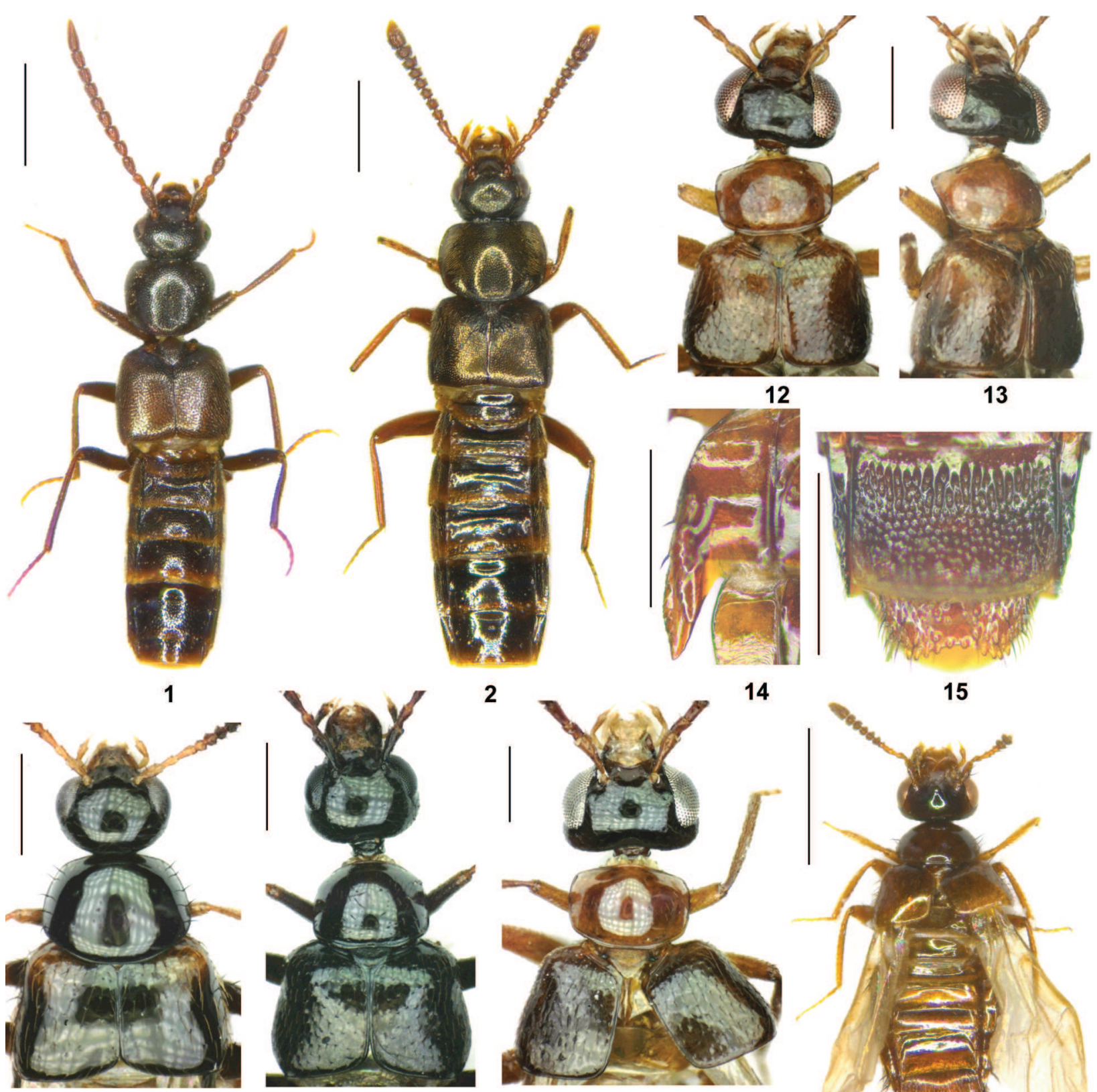

6

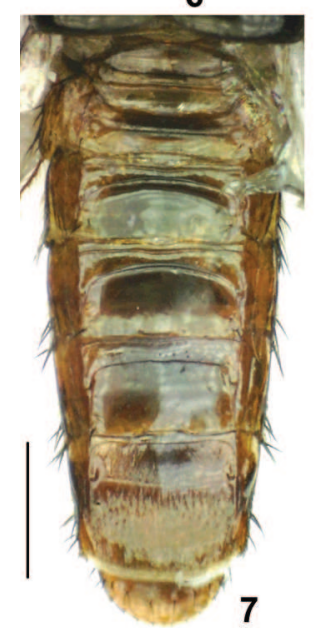

8

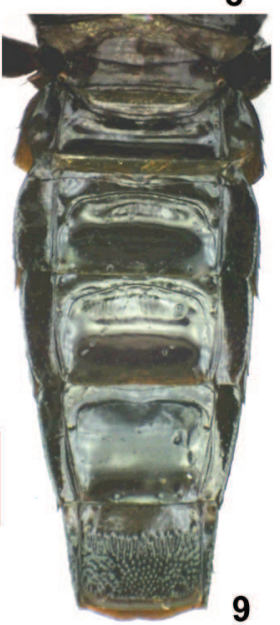

2

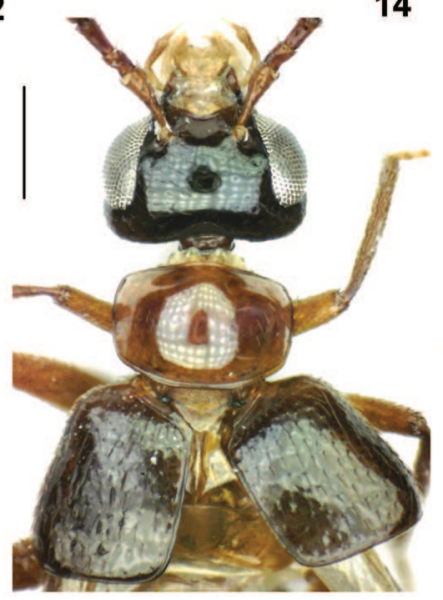

10

4
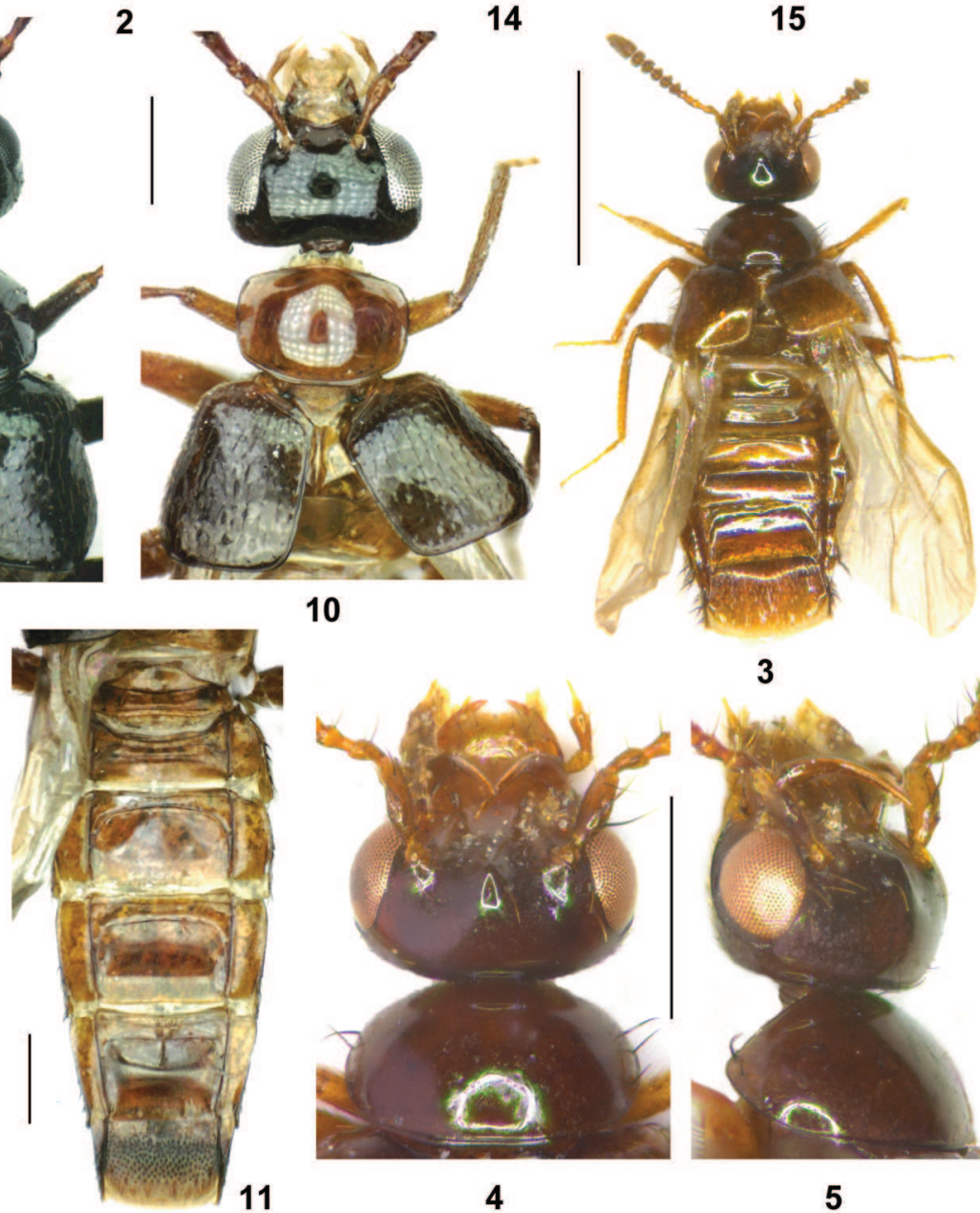

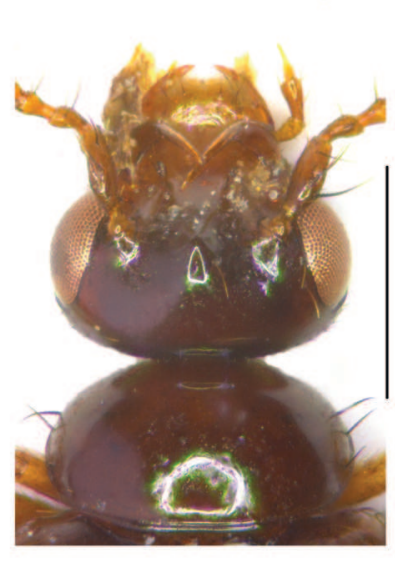

4
3

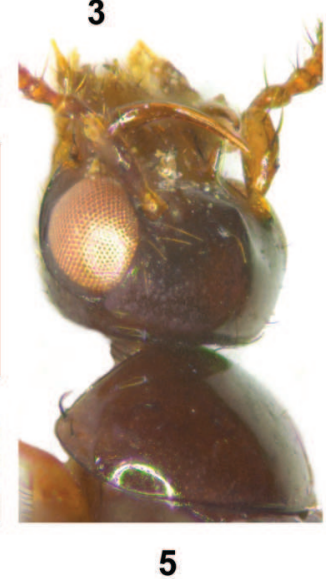

Figs 1-15: Myrmoecia urartu (1), Pella feldmanni (2), Orphnebius taurus (3-5), O. fortesetosus (6-7), O. morulus (8-9), O. globifer (10-11), and $O$. elevatus (12-15): habitus (1-3); head and pronotum (4-5); forebody $(6,8,10,12-13)$; abdomen $(7,9$, 11); anterolateral portion of abdomen (14); tergites VII-VIII (15). Scale bars: 1-3: 1.0 mm; 4-15: 0.5 mm. 

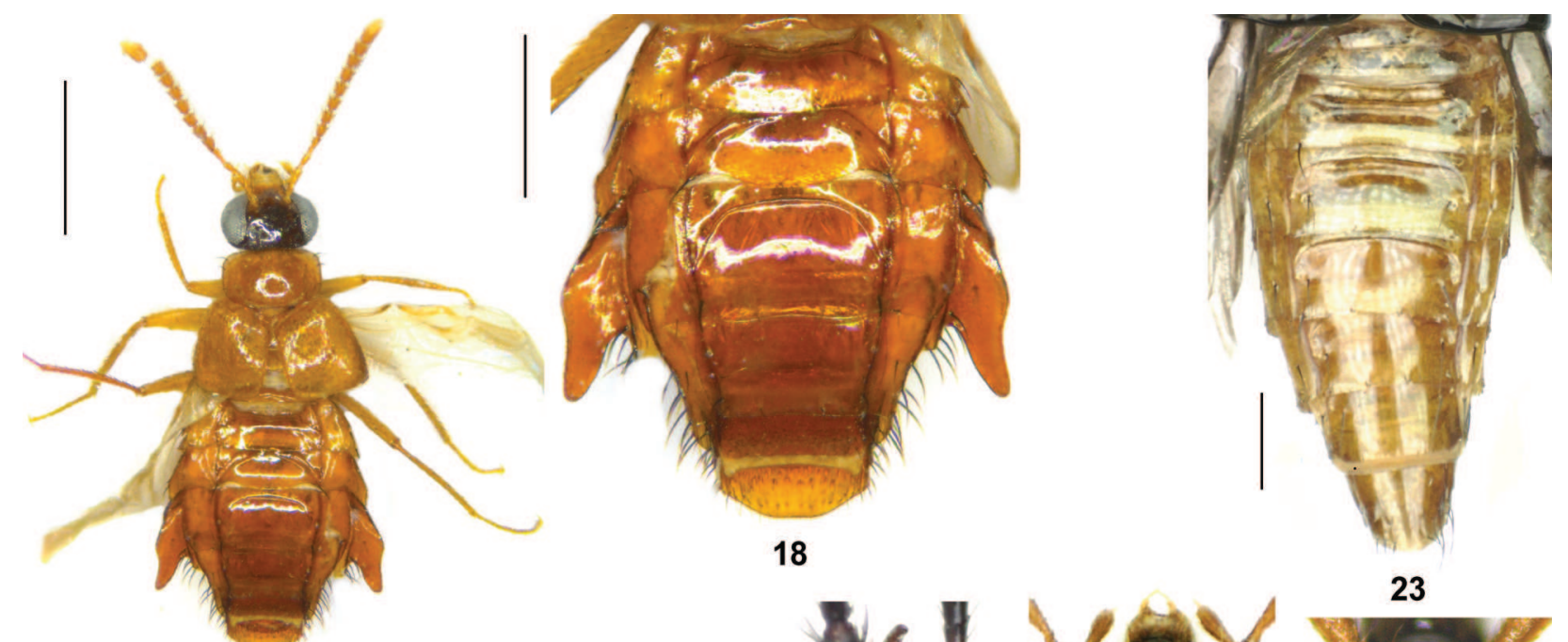

18

23

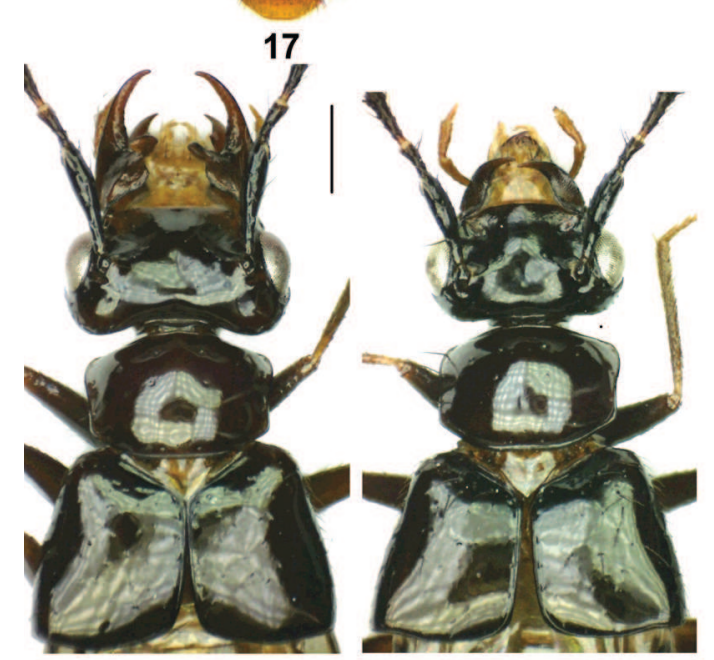

19

20

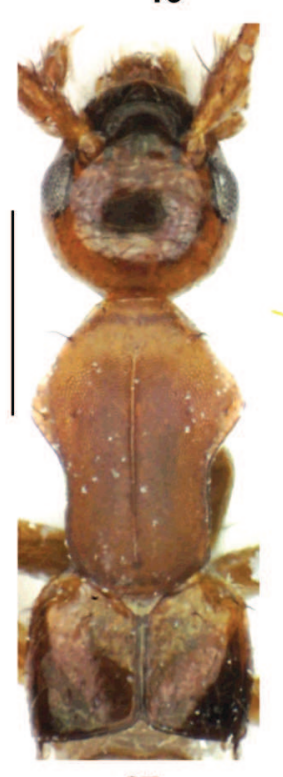

27

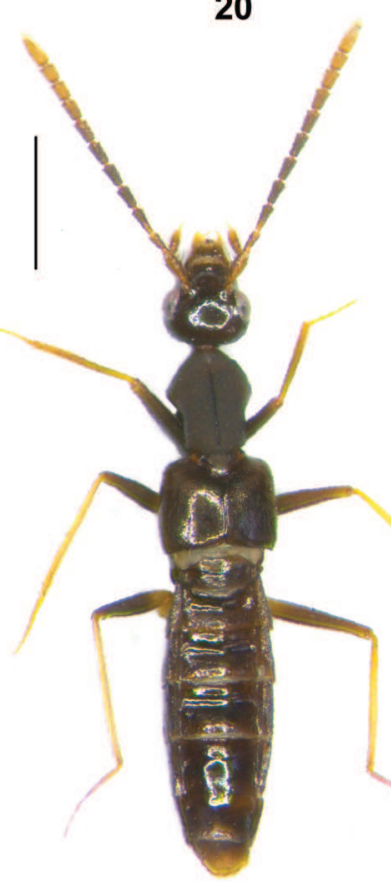

29

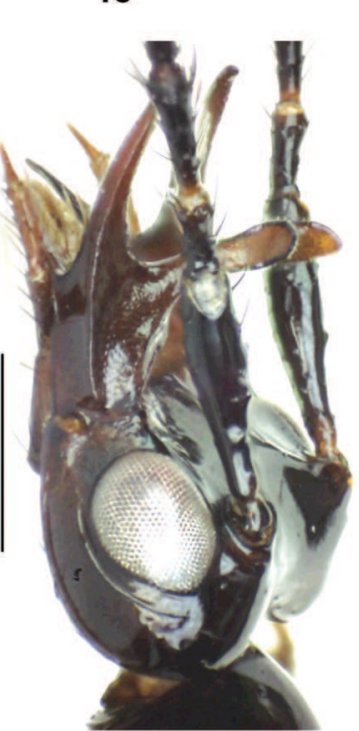

21

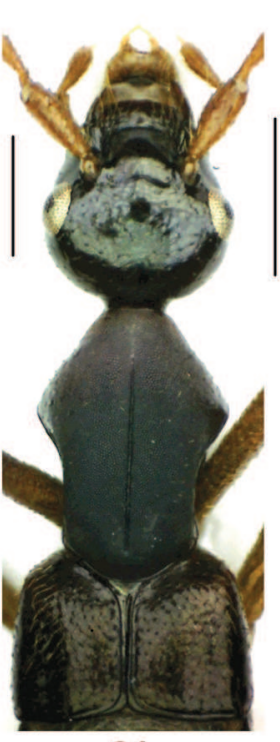

24

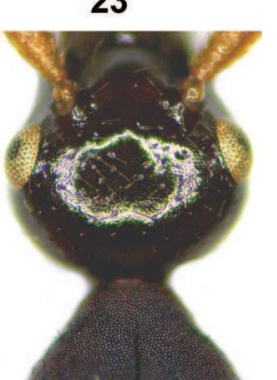

25
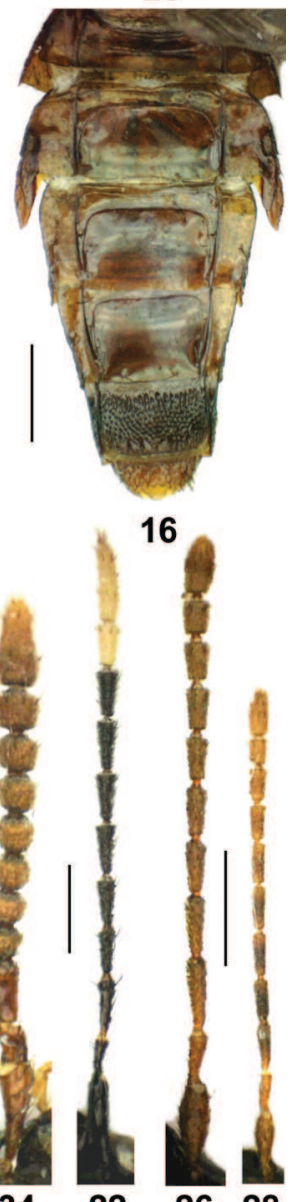

Figs 16-34: Orphnebius elevatus (16,33), O. moruliflavus (17-18), Keratodegnathus cornutus (19-23; 19, 21-23: male; 20: female), Amaurodera schmidti (24-26), A. brevipennis (27-28), A. atra (29-30), Orphnebius fortesetosus (31), O. morulus (32), and O. globifer (34): abdomen $(16,18,23)$; habitus $(17,29)$; forebody $(19-20,24,27,30)$; head in lateral view $(21)$; antenna $(22,26,29$, 31-34); head (25). Scale bars: 17, 29: $1.0 \mathrm{~mm}$; 16, 18-28, 30-34: $0.5 \mathrm{~mm}$. 

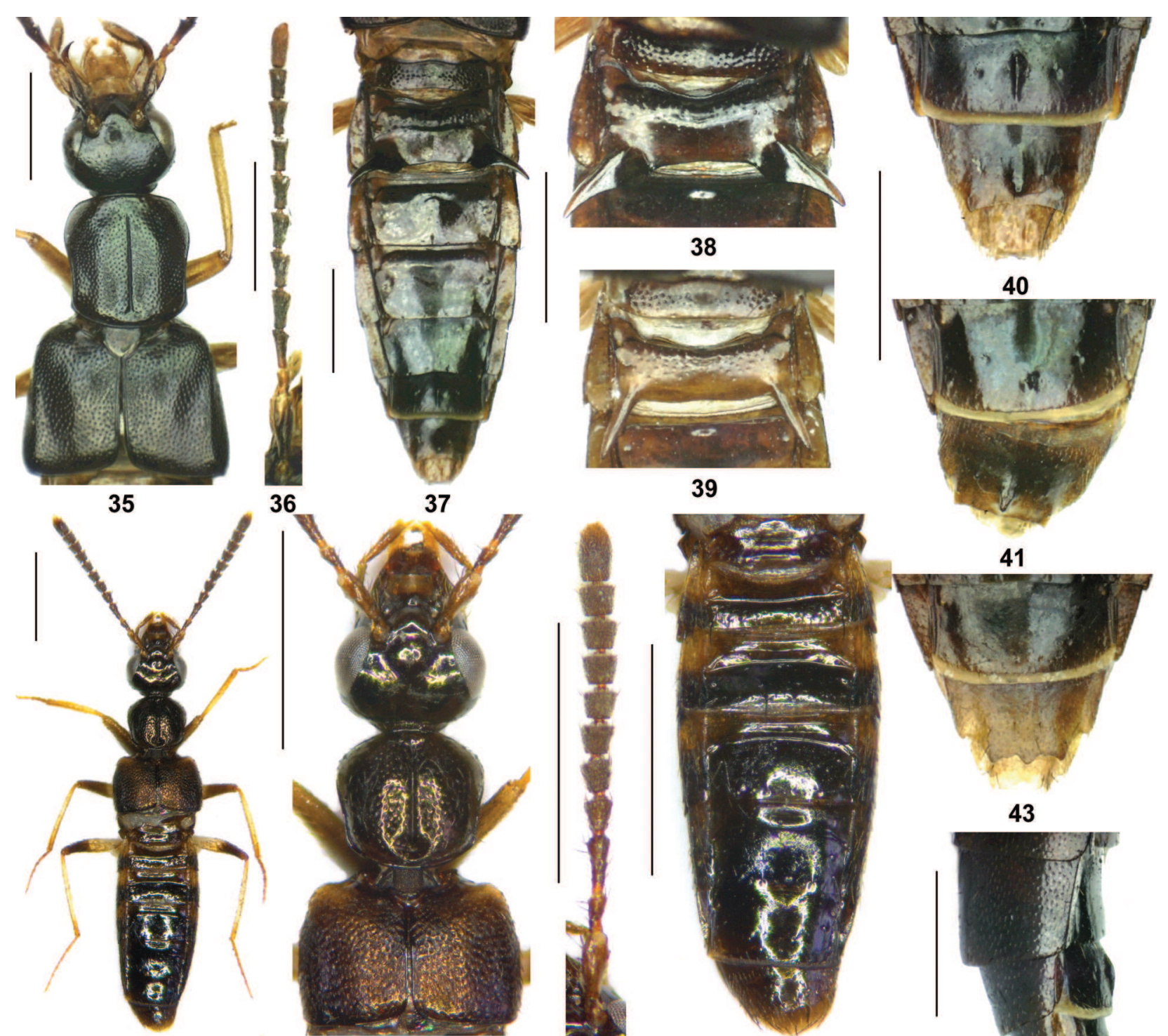

39
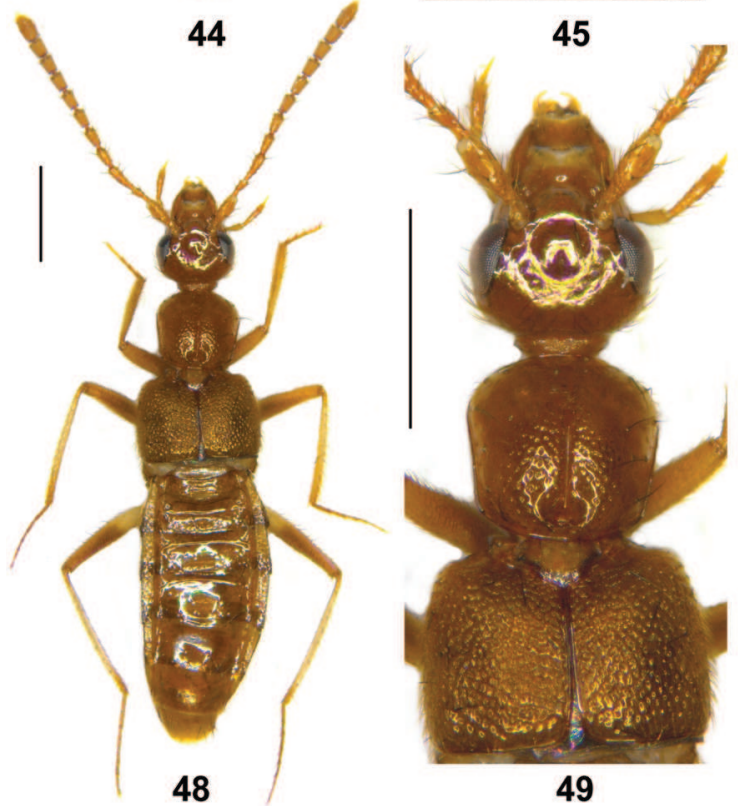

49
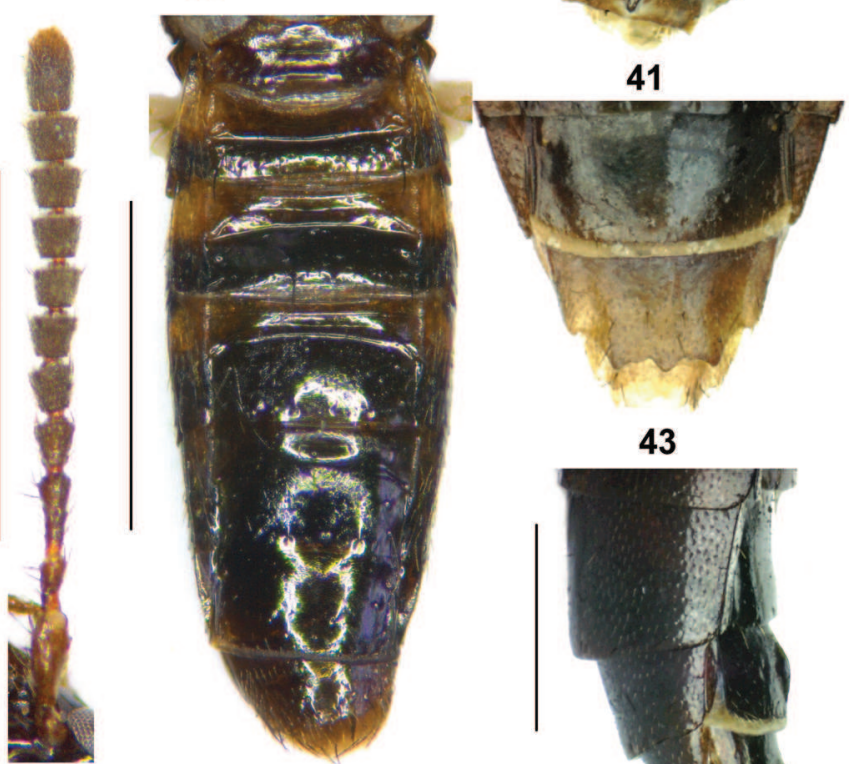

43

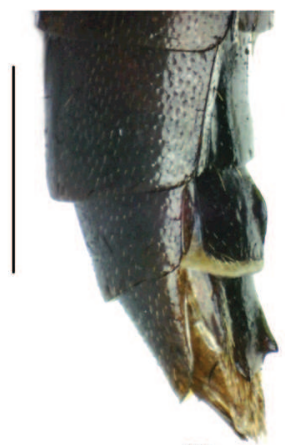

46

47
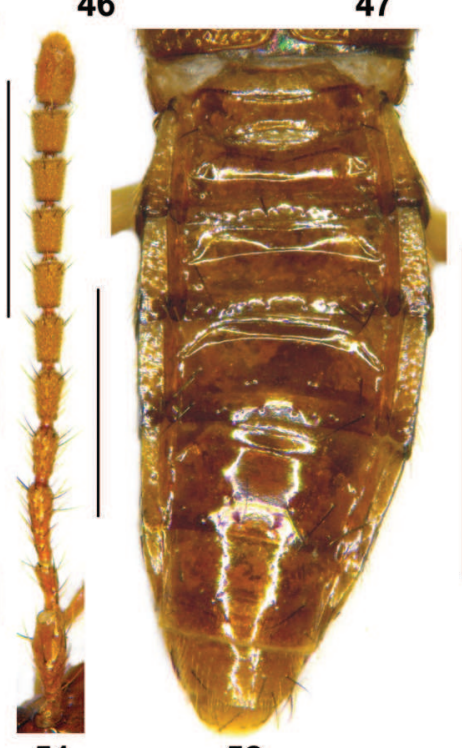

52

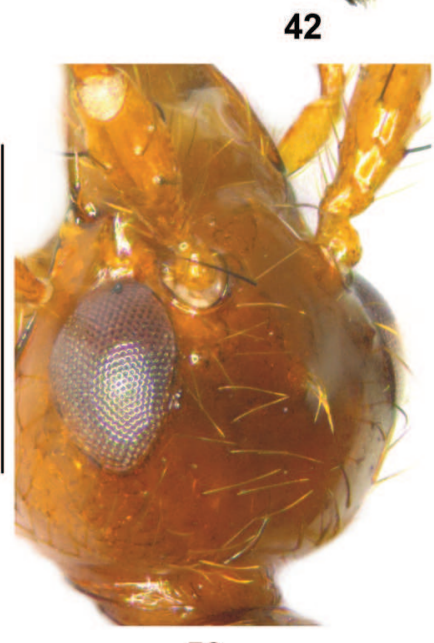

50

Figs 35-52: Drusilla bispinosa (35-43), D. shavrini (44-47), and D. penicillata (48-52): male forebody (35, 45, 49); antenna $(36,46,51)$; male abdomen $(37,47,52)$; anterior portion of male abdomen $(38-39)$; posterior portion of male abdomen in dorsal and in lateral view (40-42); posterior portion of female abdomen (43); habitus $(44,48)$; head in dorso-lateral view (50). Scale bars: 35-49, 51-52: $1.0 \mathrm{~mm}$; 50: $0.5 \mathrm{~mm}$. 


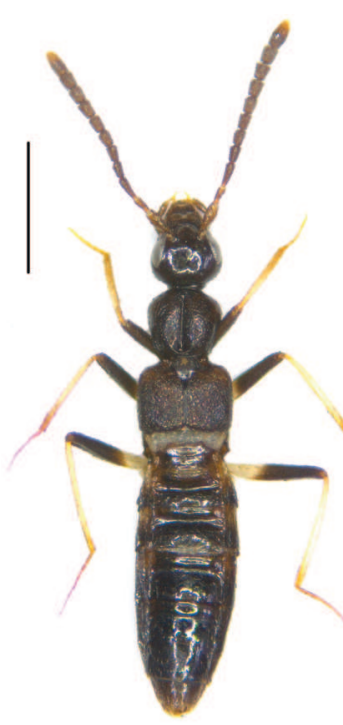

53

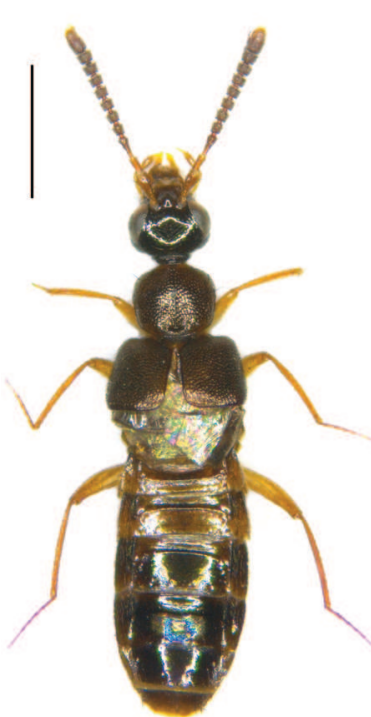

59

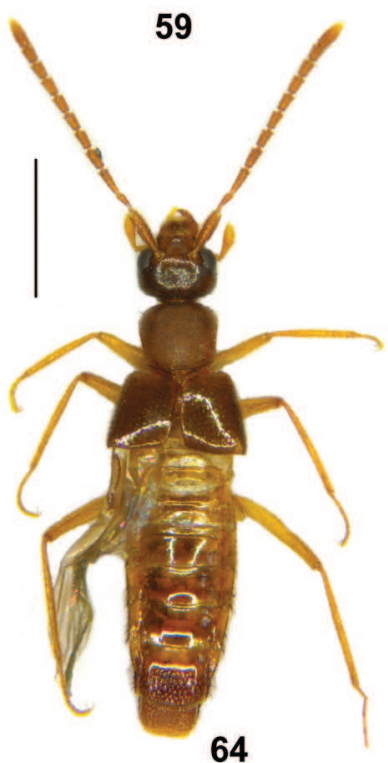

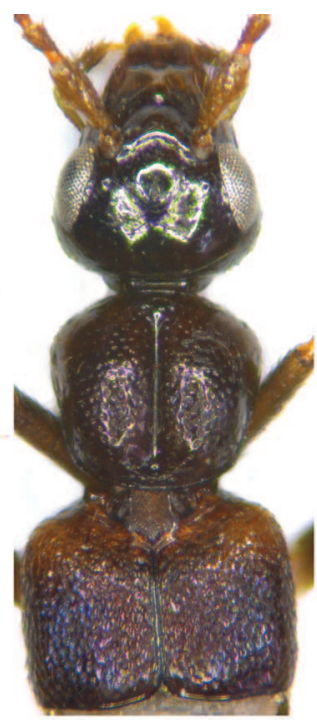

54

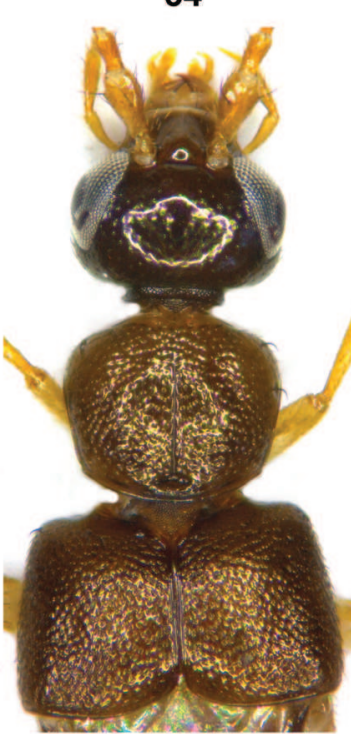

60

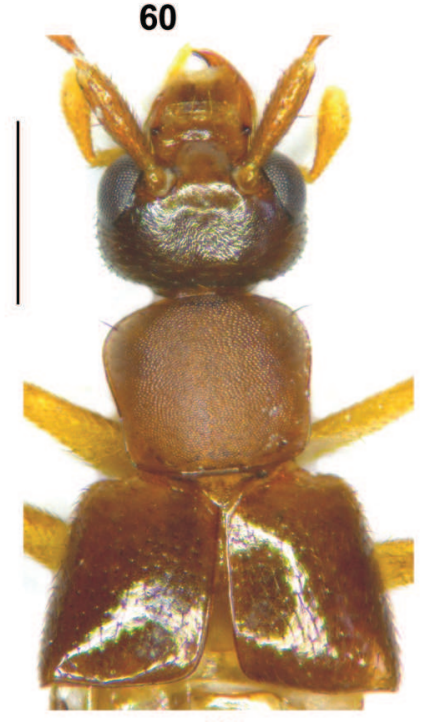

65

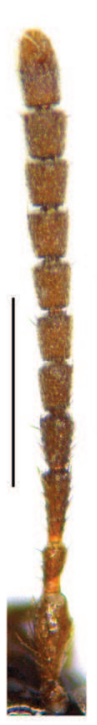

55

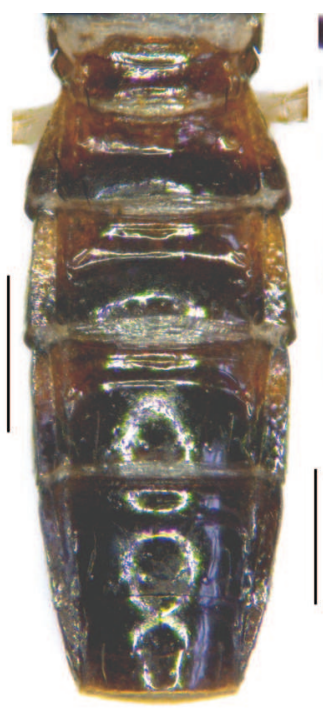

56

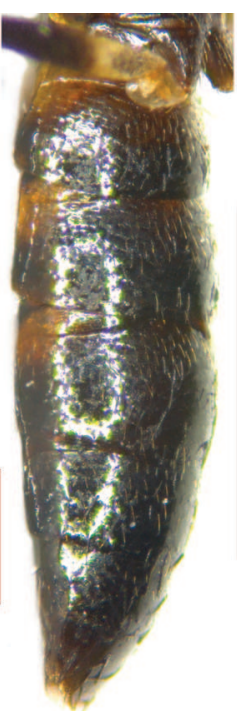

57

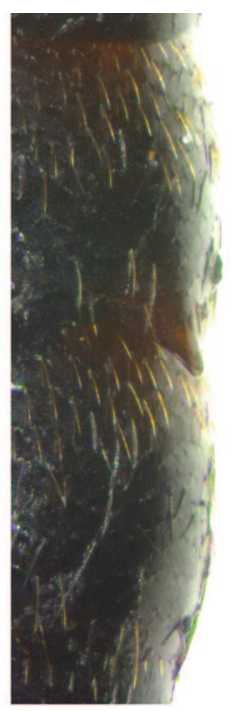

58

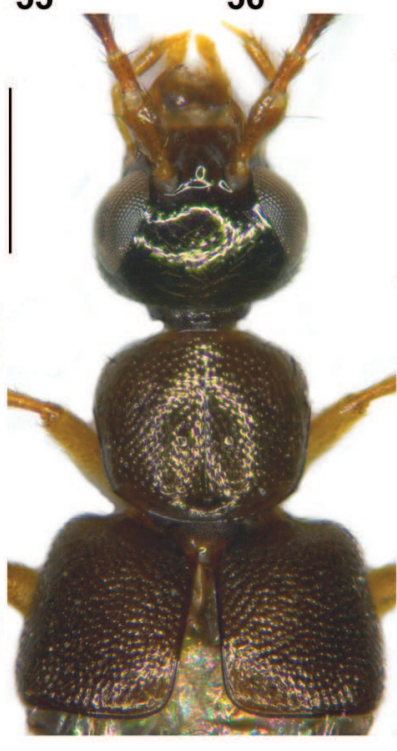

61

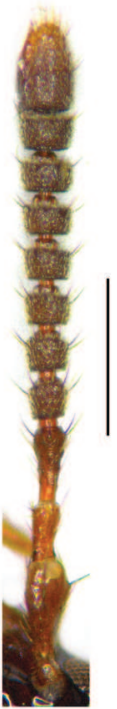

62

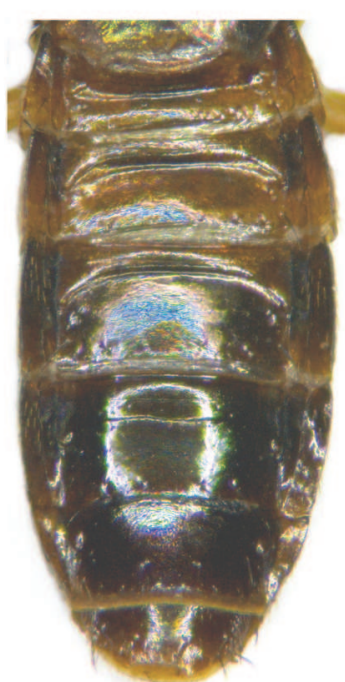

63

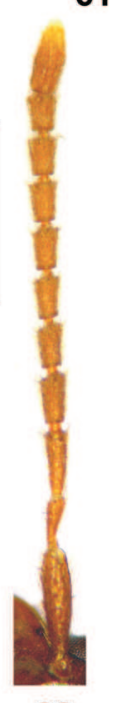

66

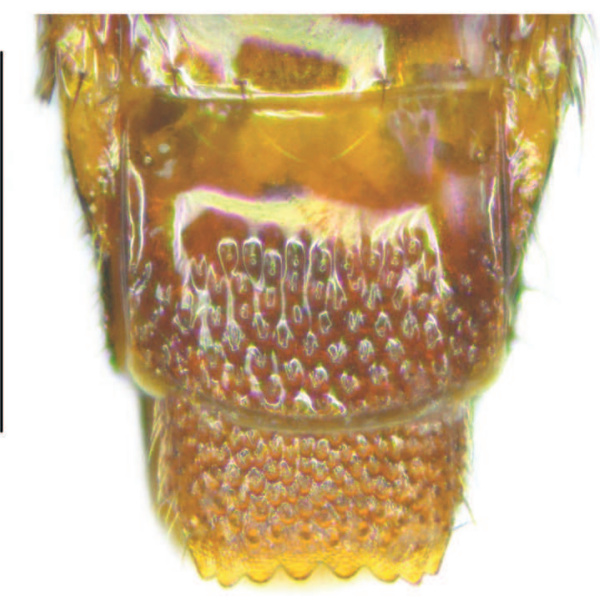

67

Figs 53-67: Drusilla spiniventris (53-58), D. breviuter (59-63), and Pheidologitonetes biplicatus (64-67): habitus (53, 59, 64); male forebody $(54,60,65)$; antenna $(55,62,66)$; abdomen $(56,63)$; male abdomen in ventro-lateral view $(57)$; male abdominal sternites IV-V in ventro-lateral view (58); female forebody (61); male tergites VII-VIII (67). Scale bars: 53, 59, 64: 1.0 mm; 54-58, 60-63, 65-67: $0.5 \mathrm{~mm}$. 


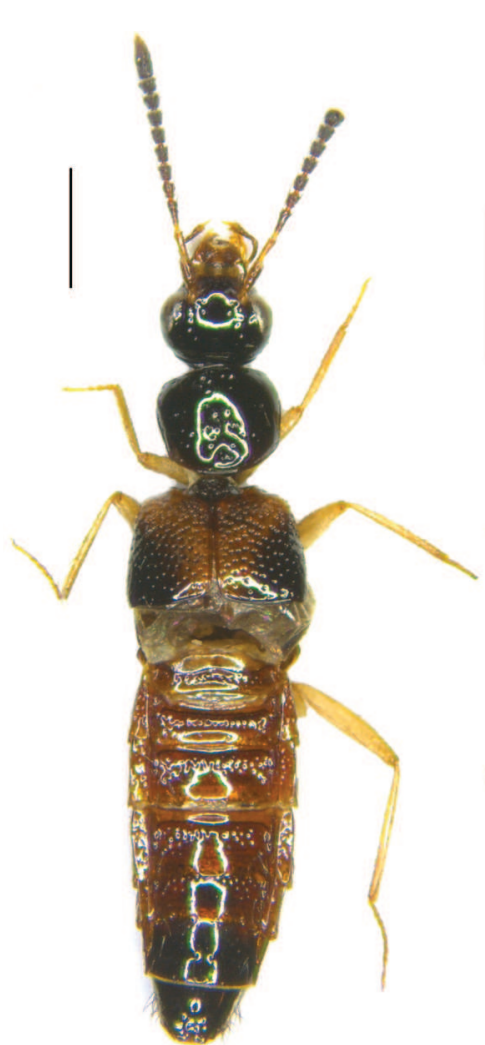

68

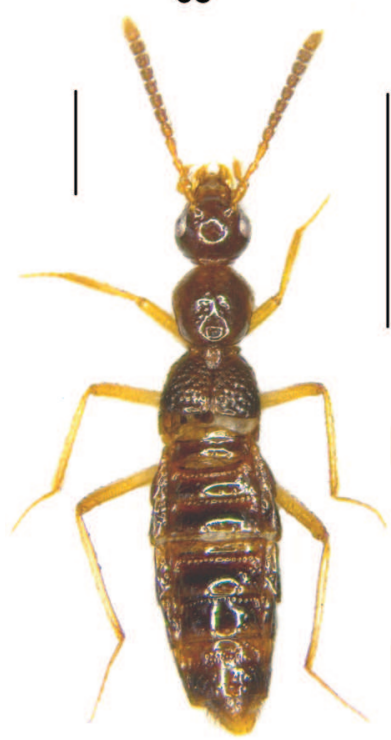

71

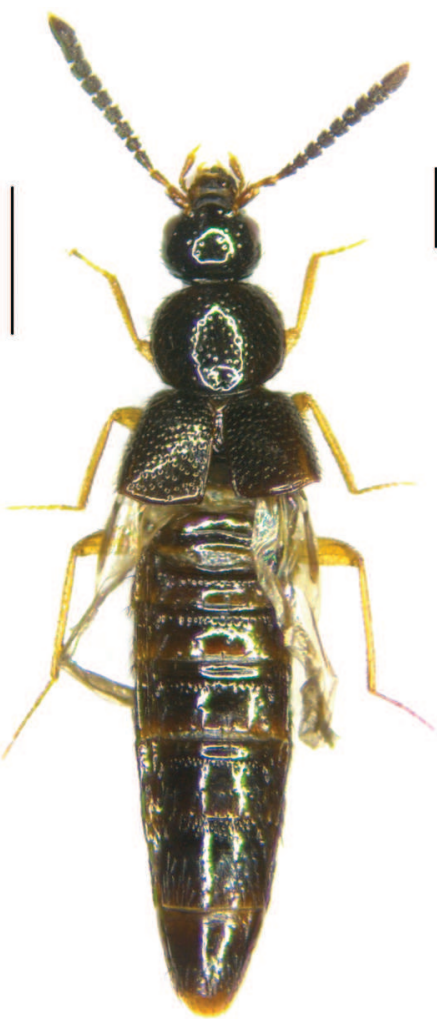

70

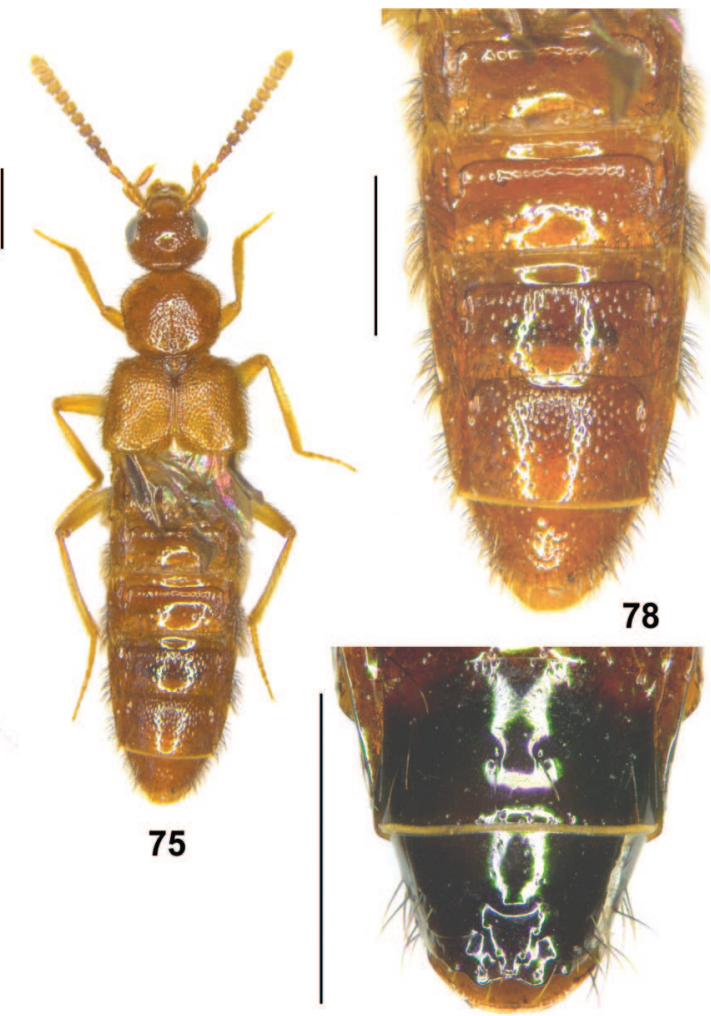

69

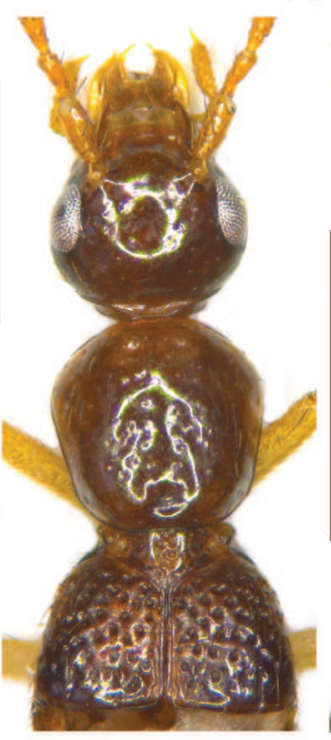

72

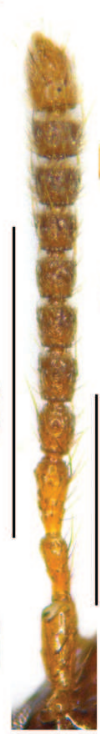

73

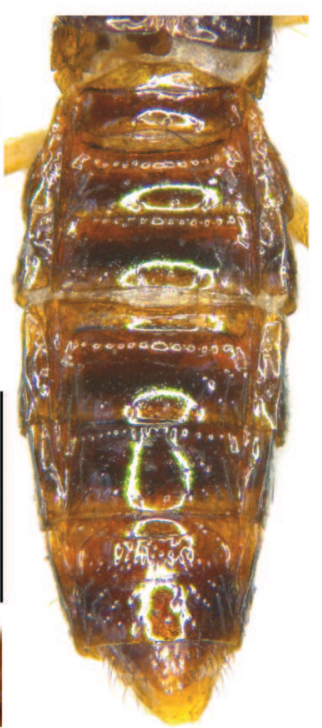

74

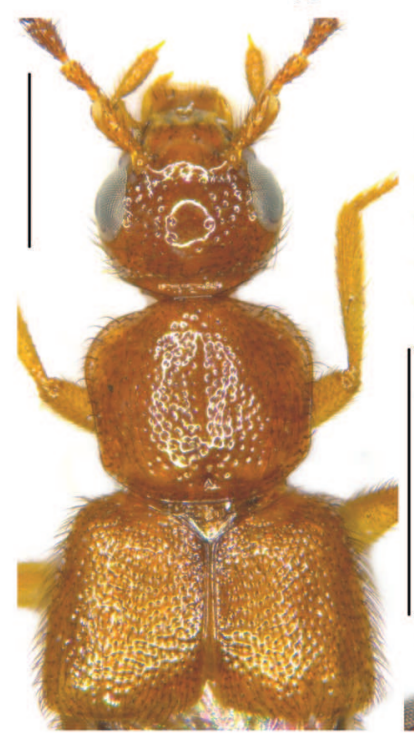

76

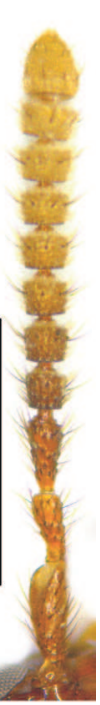

77

Figs 68-78: Zyras conlectus (68-69), Z. hetzeli (70), Z. reductus (71-74), and Z. shavrini (75-78): habitus (68, 70-71, 75); posterior portion of male abdomen $(69)$; forebody $(72,76)$; antenna $(73,77)$; abdomen $(74,78)$. Scale bars: $1.0 \mathrm{~mm}$.

Orphnebius spinans Assing, 2016

Material examined: India: $10^{\top}$, Arunachal Pradesh, Etalin env., $28^{\circ} 37^{\prime} \mathrm{N}, 95^{\circ} 53^{\prime} \mathrm{E}, 700 \mathrm{~m}, 12-25 . \mathrm{V} .2102$, leg. Šauša (cAss).

The above specimen was collected together with the holotype.

\section{Orphnebius schuelkei Assing, 2006}

Material examined: China: 36 exs., N-Sichuan, Xiao-Zhaizi National Nature Reserve, 7 km W Qingpianxiang, Xiaozhaizi, $32^{\circ} 01^{\prime} \mathrm{N}, 103^{\circ} 56^{\prime} \mathrm{E}, 1560-1700 \mathrm{~m}$, flight interception trap, 27.VI.-1.VII.2017, leg. Kabátek et al. (MMB, cAss).

This species has been recorded only from Sichuan and the border region of Shaanxi and Chongqing. 


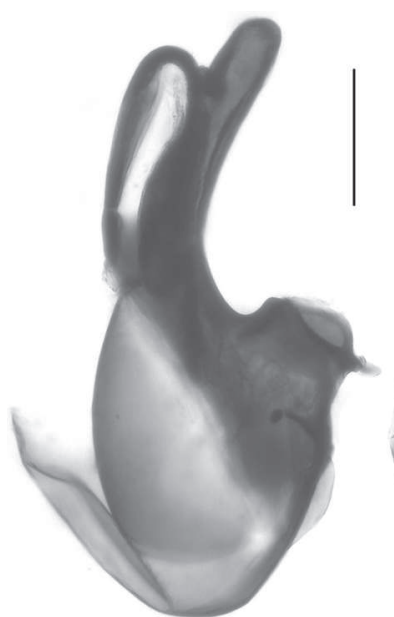

80

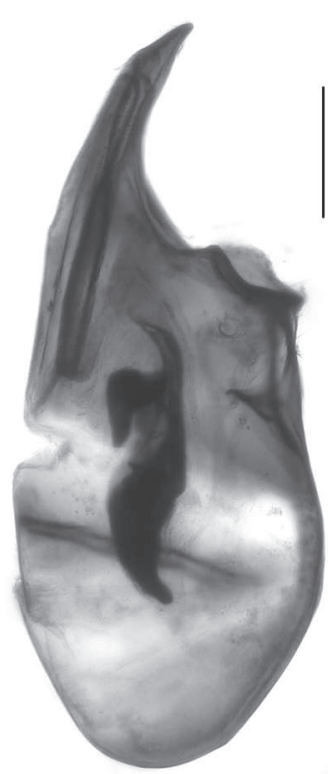

84

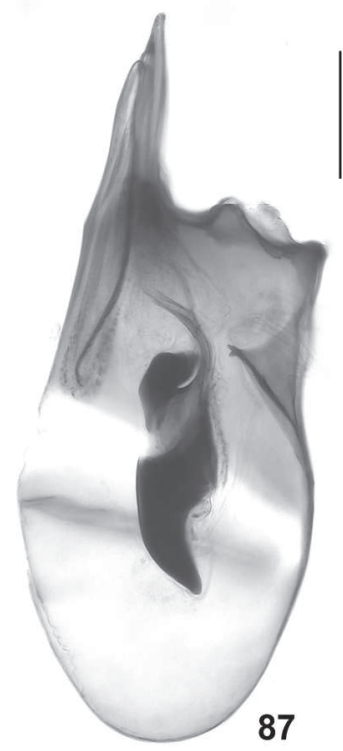

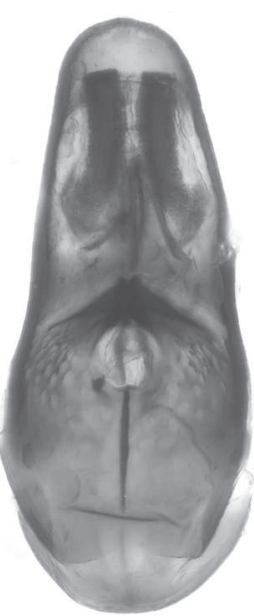

81

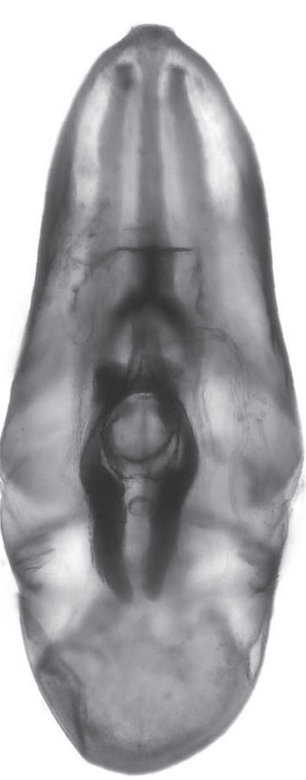

85

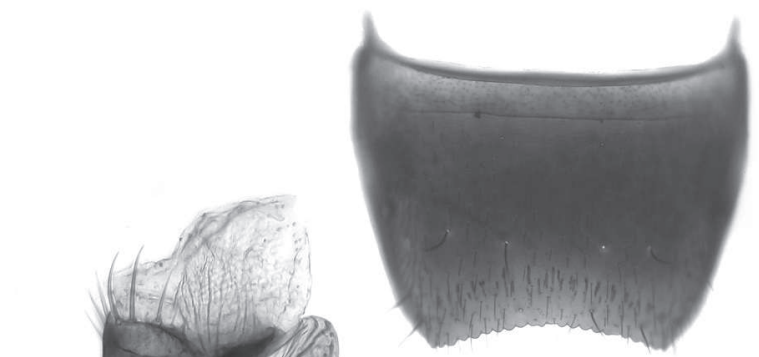

82

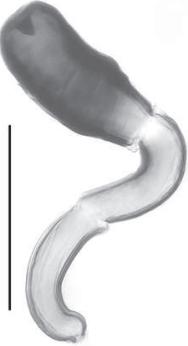

79

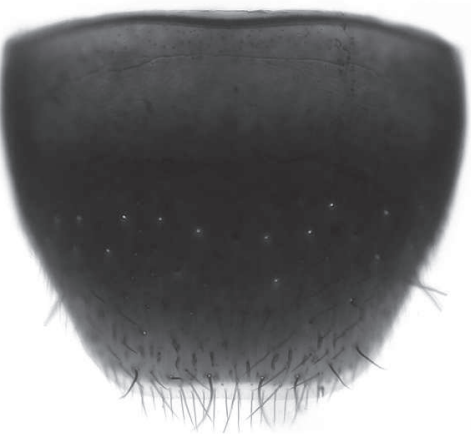

86

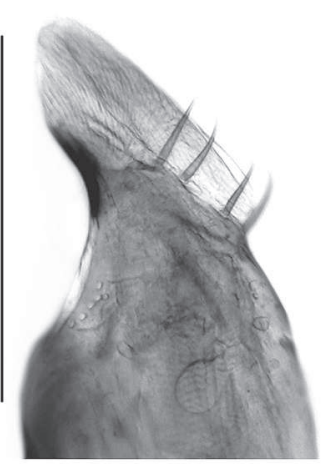

90

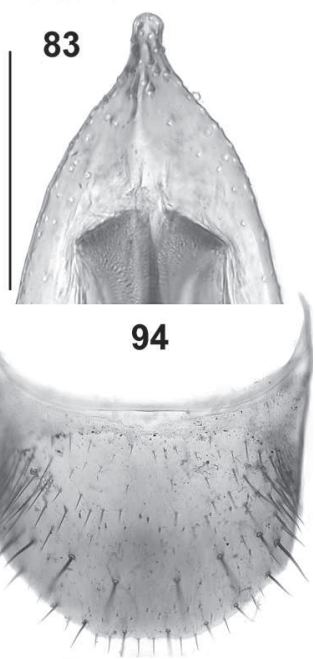

95
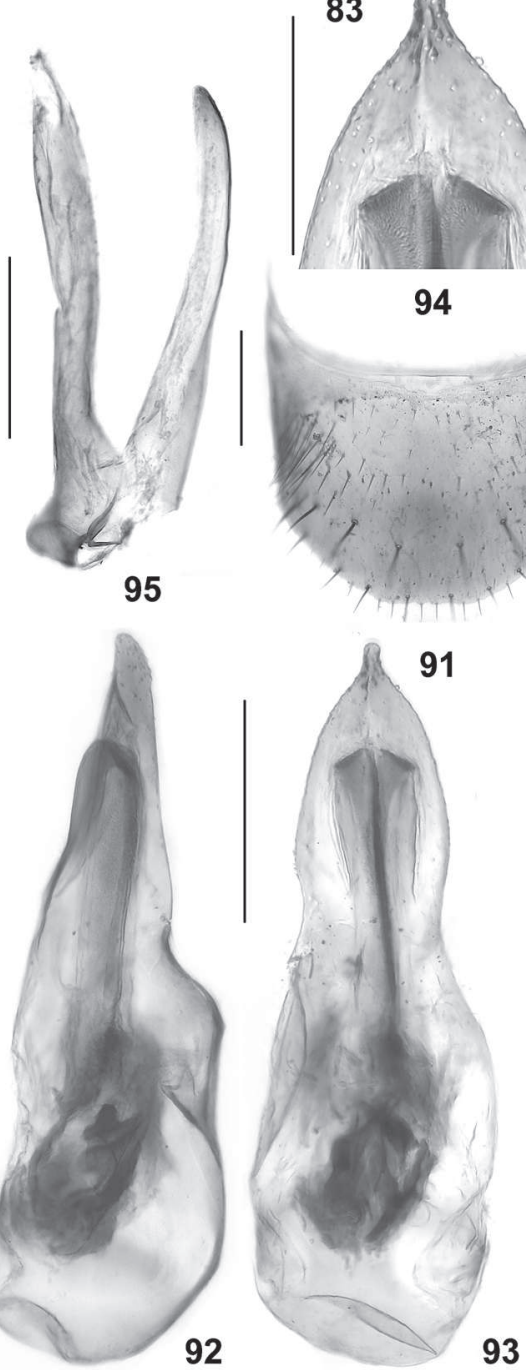

Figs 79-95: Myrmoecia urartu (79), Pella feldmanni (80-83), Orphnebius cachemiricus (84-86), O. fortesetosus (87-90), and O. taurus (91-95): spermatheca (79); median lobe of aedeagus in lateral and in ventral view (80-81, 84-85, 87-88, 92-93); male tergite VIII $(82,91)$; male sternite VIII $(83)$; paramere $(86,89,95)$; apical portion of paramere $(90)$; apical portion of median lobe of aedeagus (94). Scale bars: 79-93, 95: $0.2 \mathrm{~mm}$; 94: $0.1 \mathrm{~mm}$. 


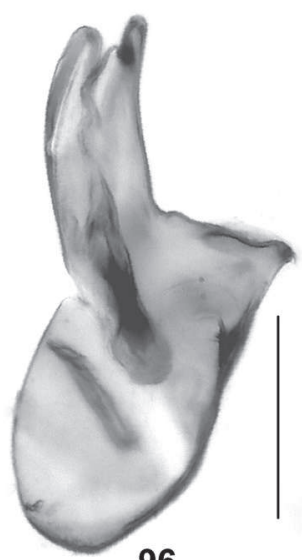

96

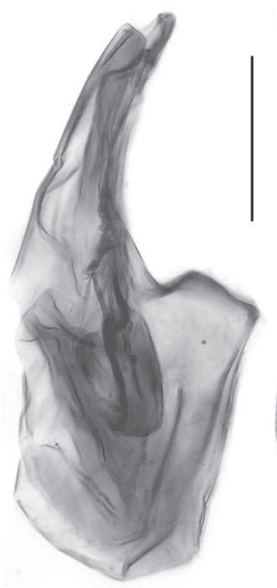

111

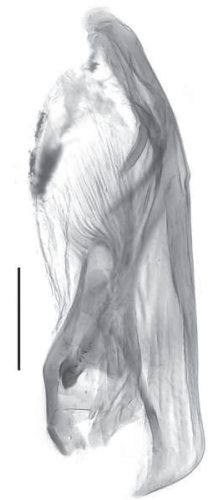

113

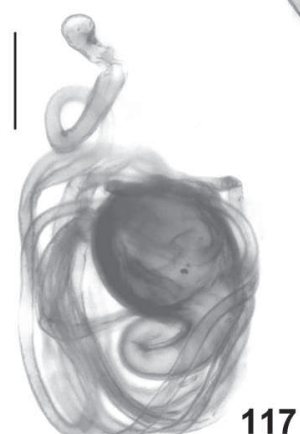

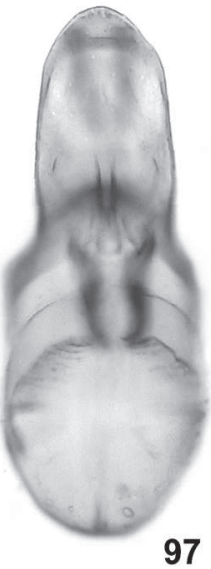

97

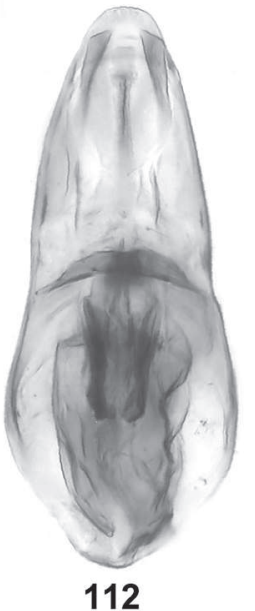

112

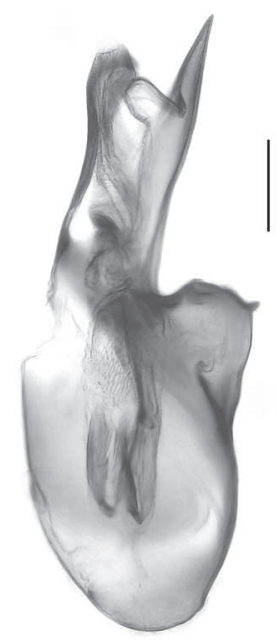

114
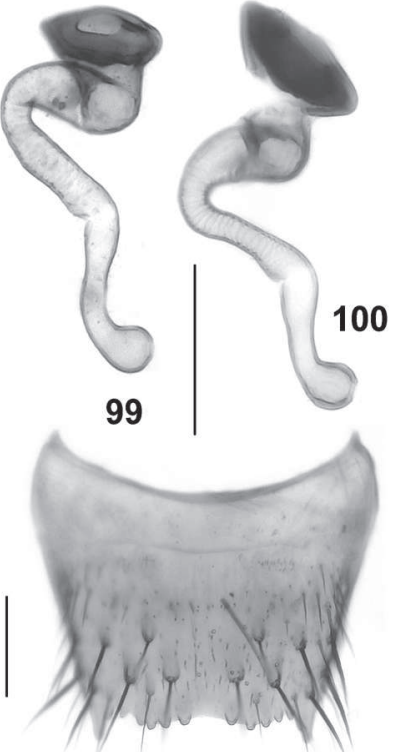

98

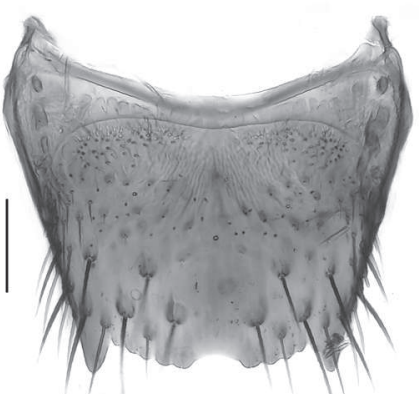

110

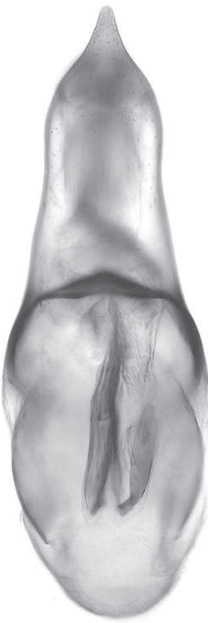

115

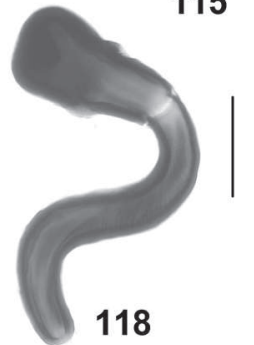

116

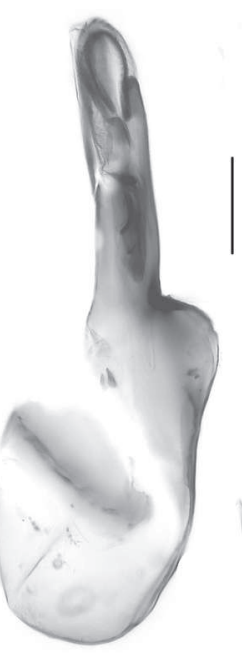

103

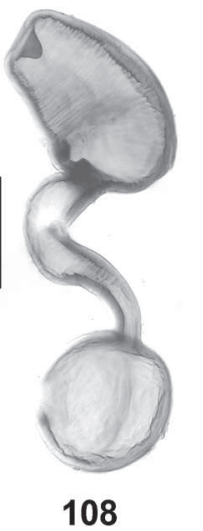

108

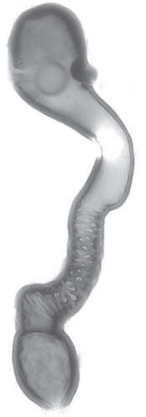

109

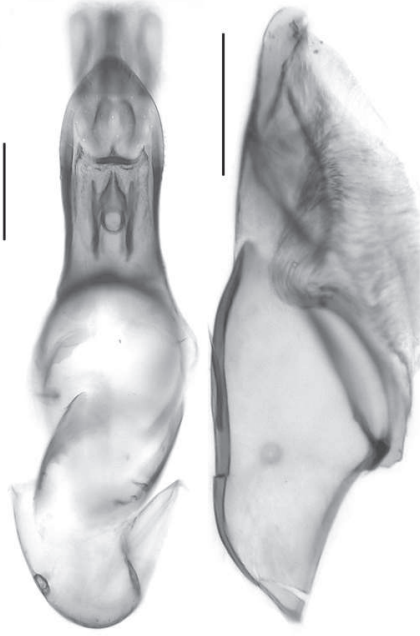

105
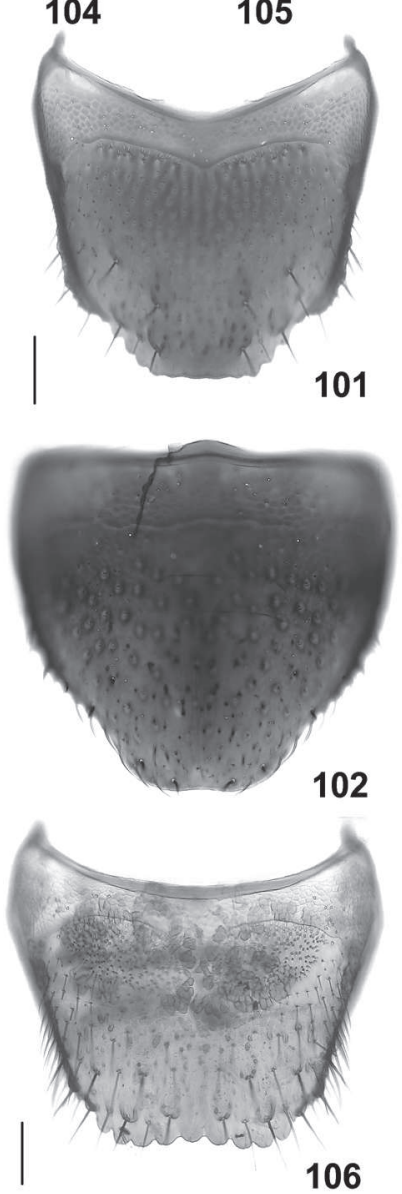

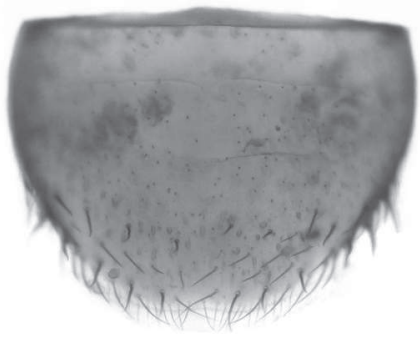

107

Figs 96-119: Orphnebius grootaerti (96-100), O. morulus (101-105), O. globifer (106-108), O. elevatus (109), O. moruliflavus (110-113), Keratodegnathus cornutus (114-117), and Amaurodera schmidti (118-119): median lobe of aedeagus in lateral and in ventral view (96-97, 103-104, 111-112, 114-115); tergite VIII $(98,101,106,110)$; male sternite VIII (102); spermatheca (99-100, 108-109, 117-119); paramere (105, 113, 116); female sternite VIII (107). Scale bars: $0.1 \mathrm{~mm}$. 


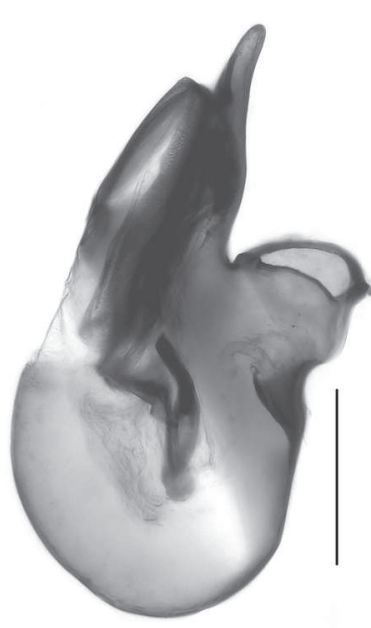

120

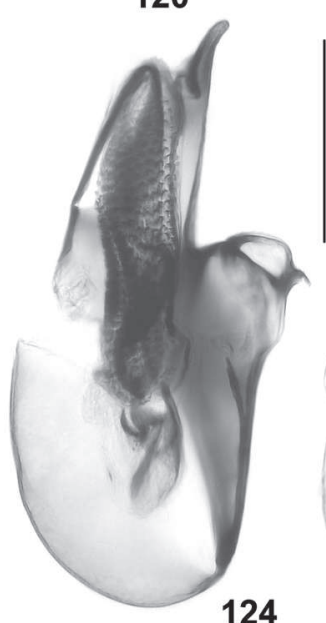

124

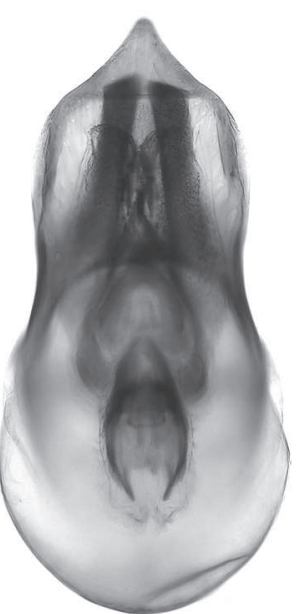

121

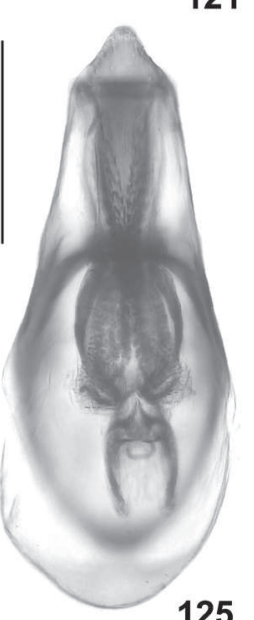

125

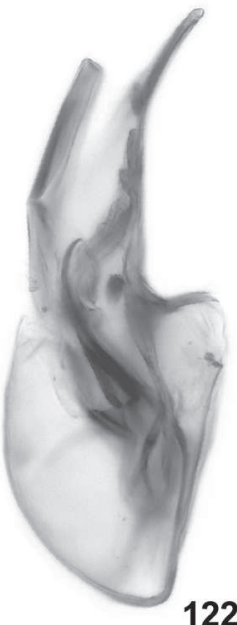

122
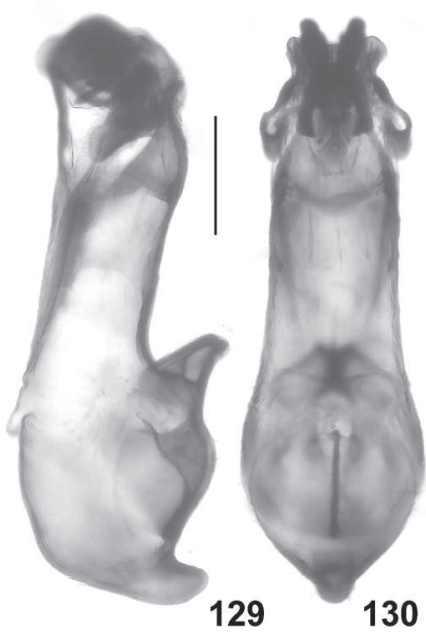

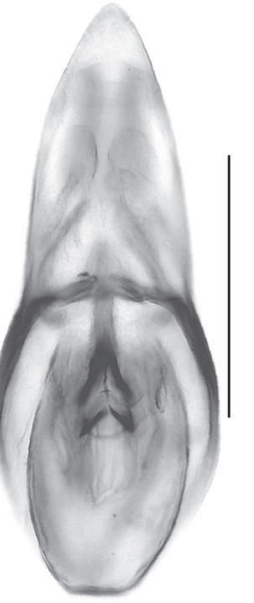

123

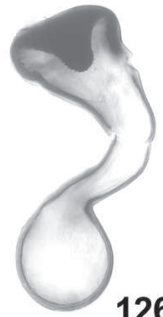

126

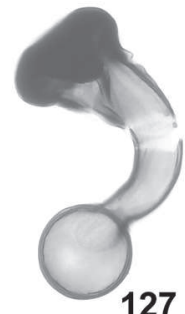

127

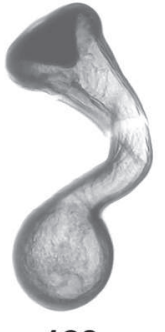

128

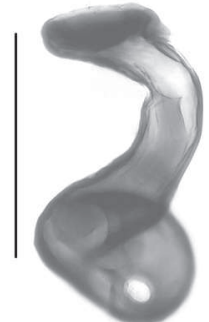

131
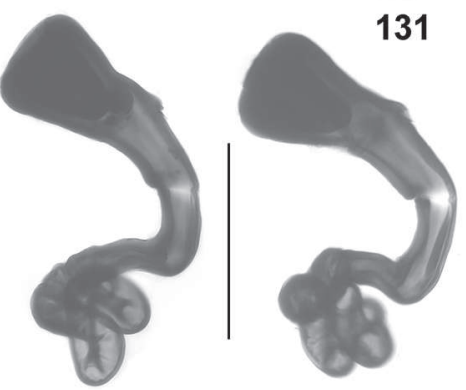

139

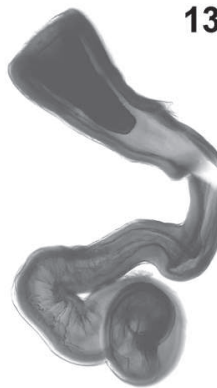

144

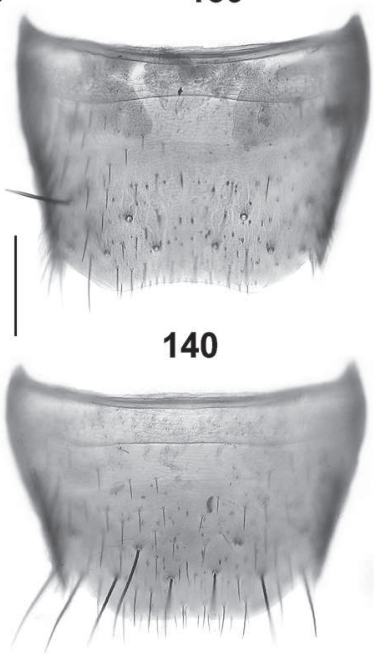

143
134

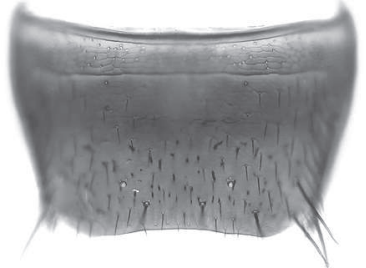

132

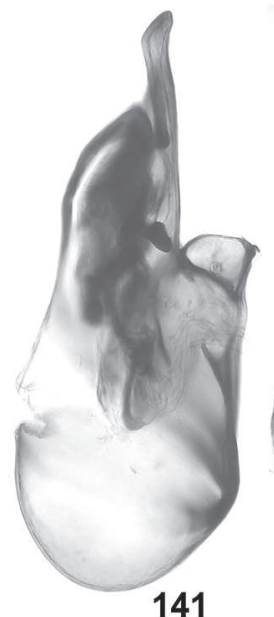

135

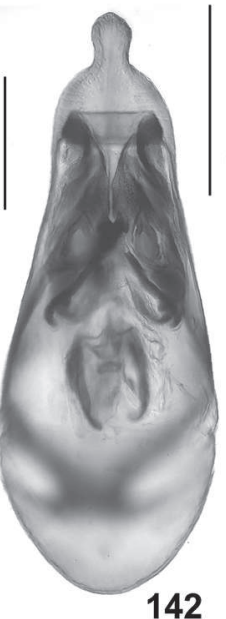

142

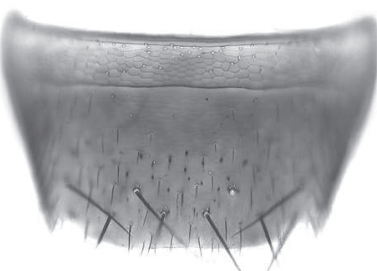

136

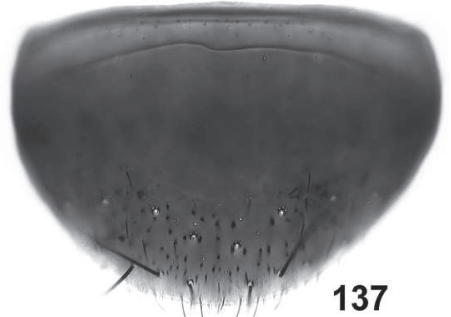

Figs 120-144: Amaurodera schmidti (120-121), A. brevipennis (122-123), A. atra (124-128), Drusilla bispinosa (129-131), D. shavrini (132-139), and D. penicillata (140-144): median lobe of aedeagus in lateral and in ventral view $(120-125,129-130$, 134-135, 141-142); spermatheca (126-128, 131, 138-139, 144); male tergite VIII (132, 140); male sternite VIII (133); female tergite VIII $(136,143)$; female sternite VIII (137). Scale bars: $0.2 \mathrm{~mm}$. 

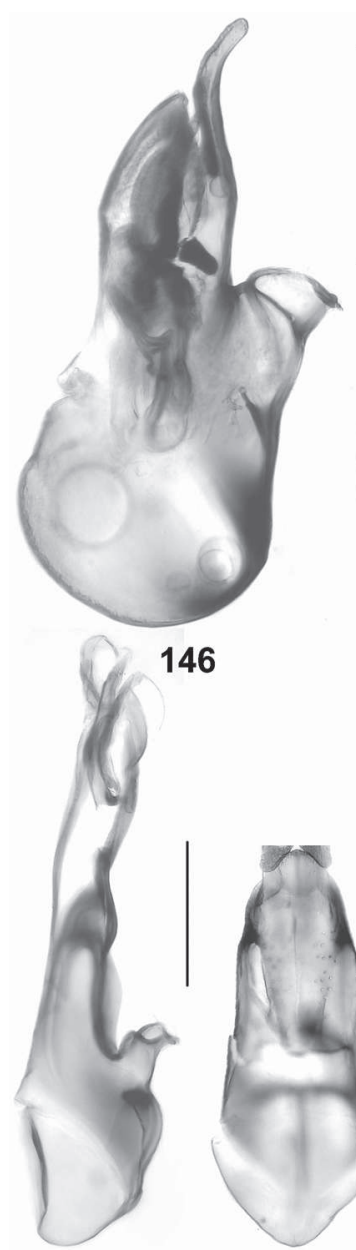

$153 \quad 154$

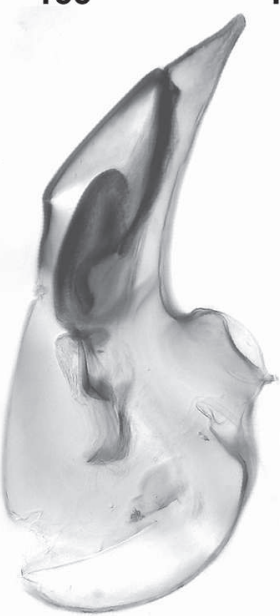

158

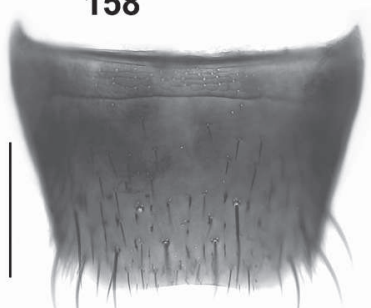

145
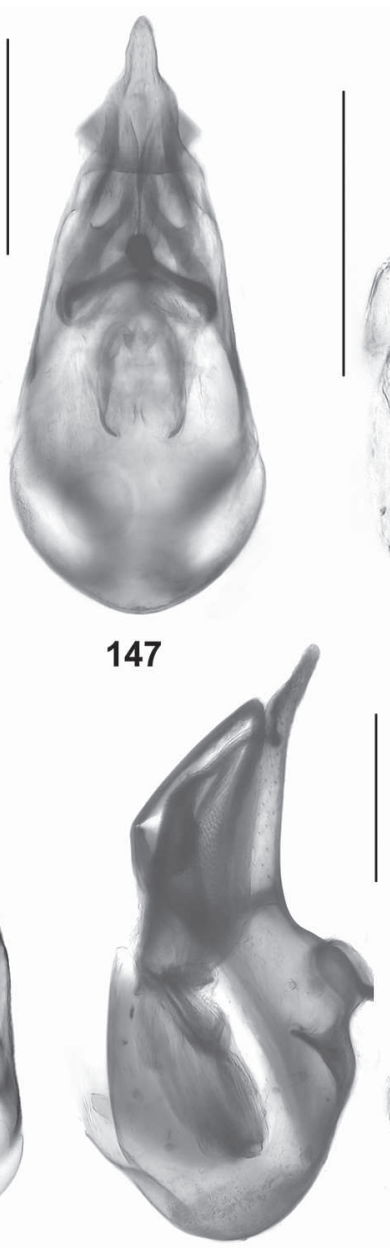

155

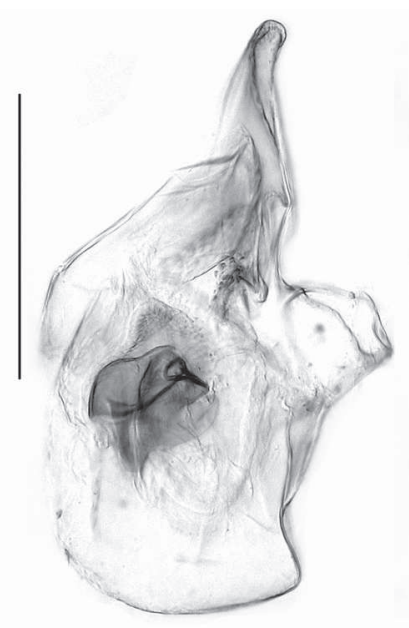

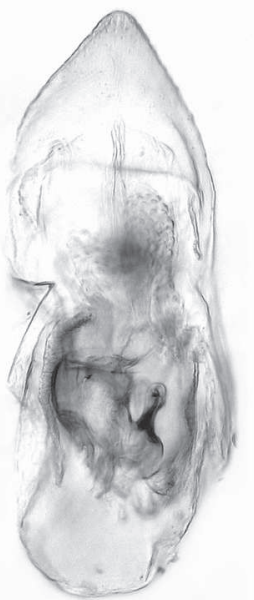

150

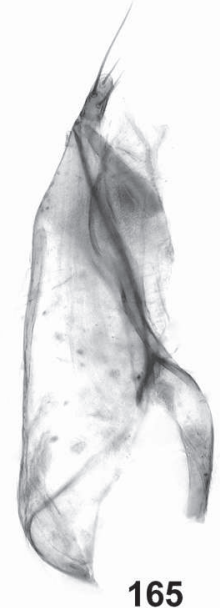

149

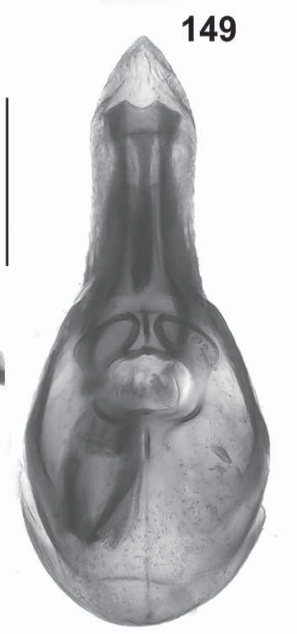

156

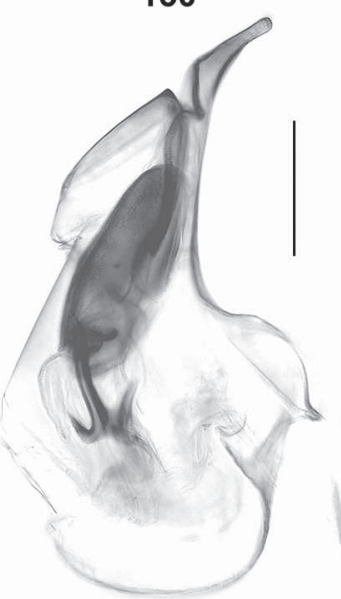

163
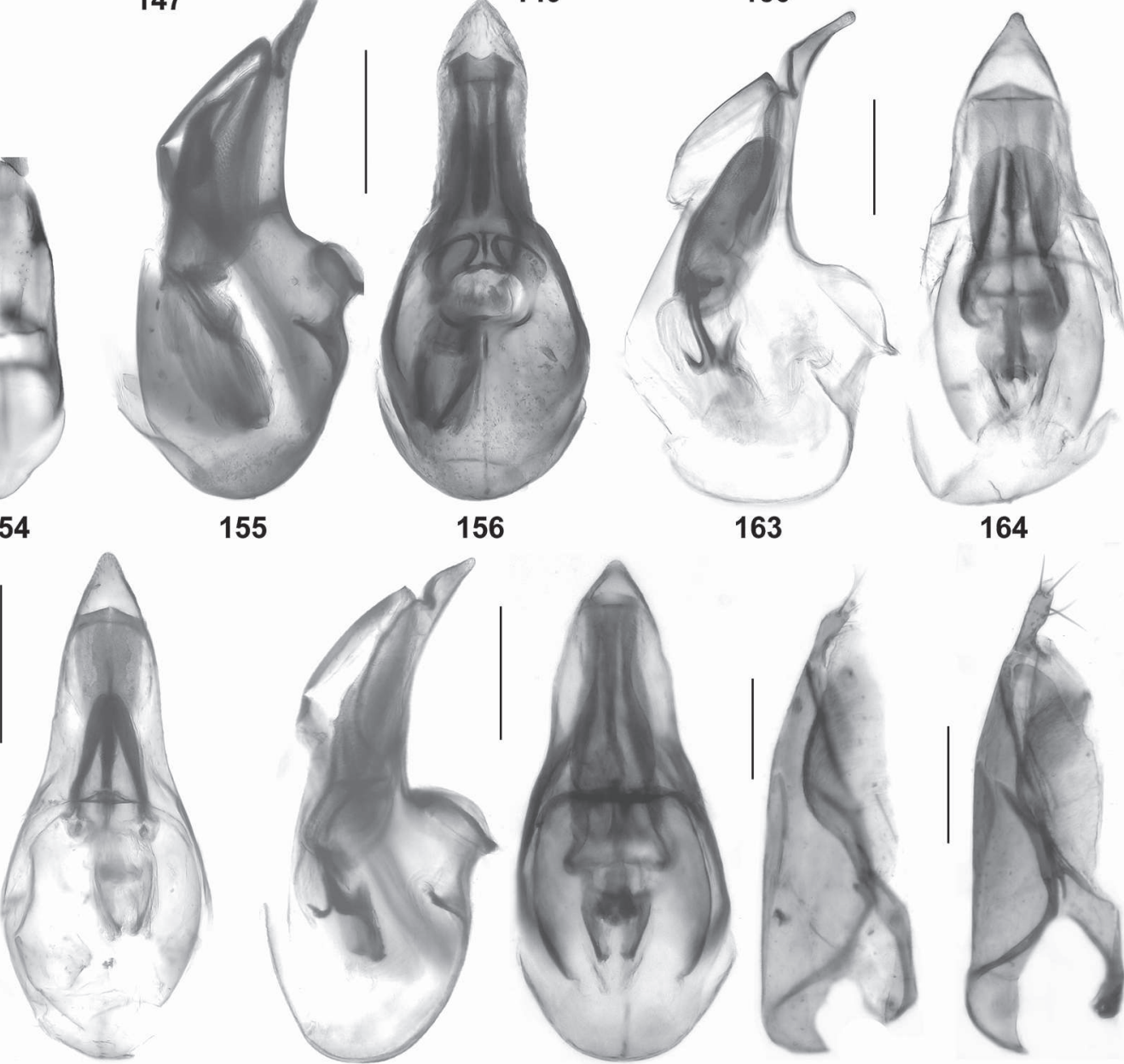

159

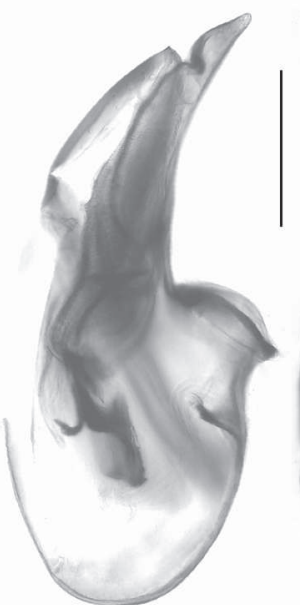

160

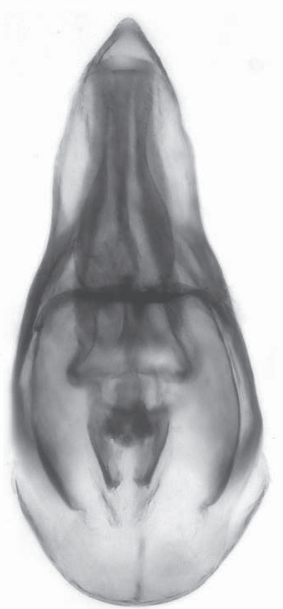

161

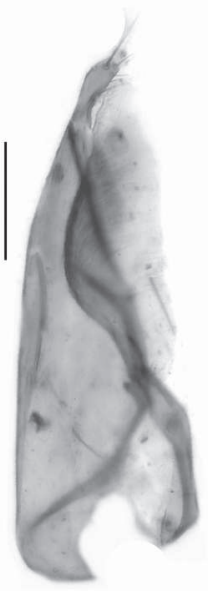

162
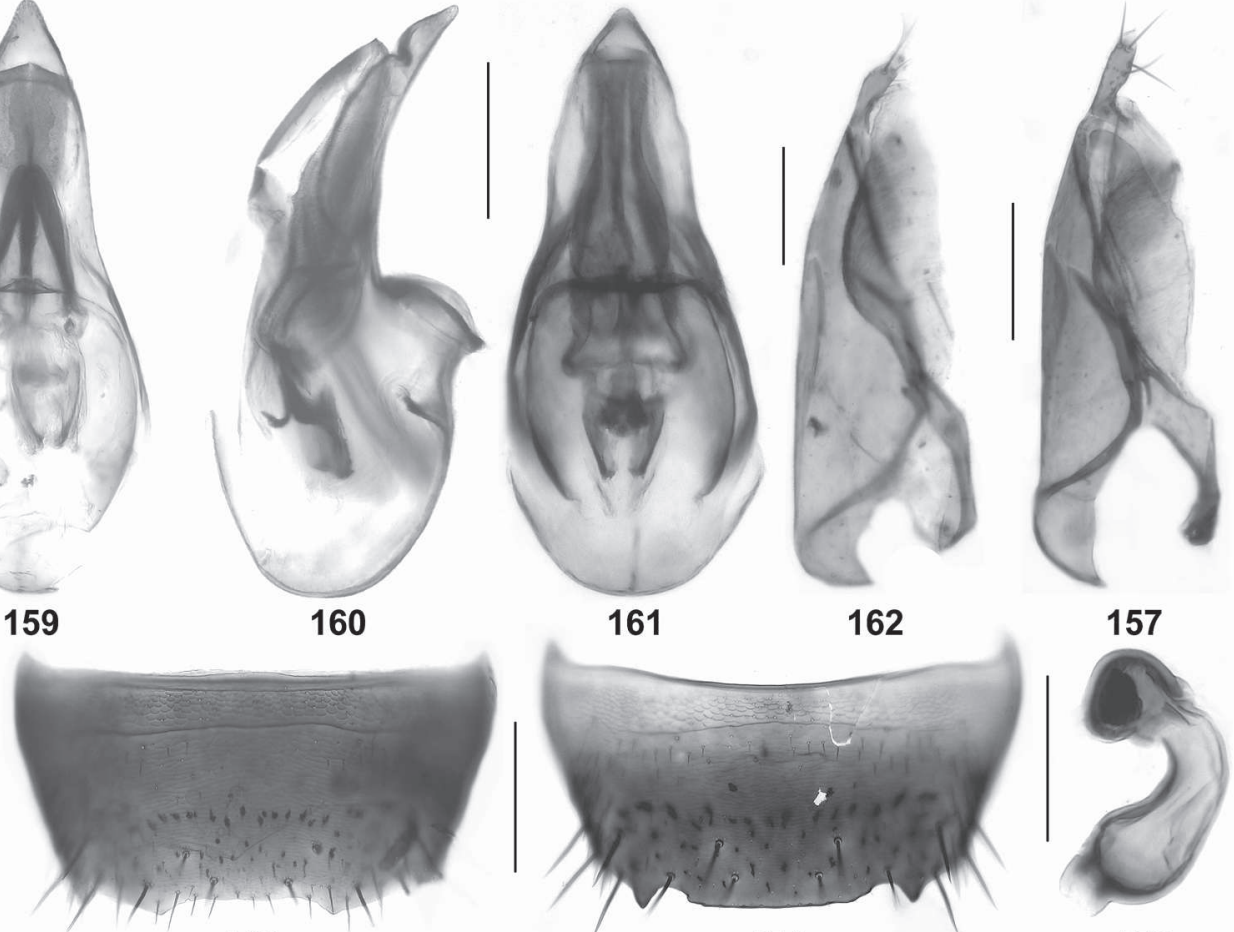

148

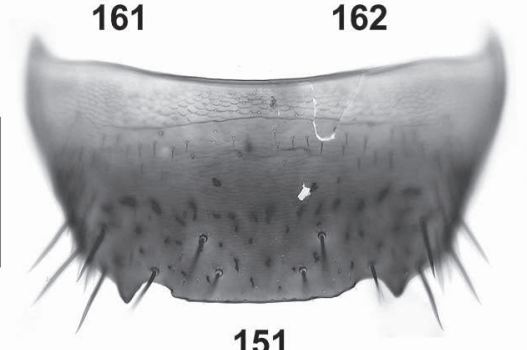

157

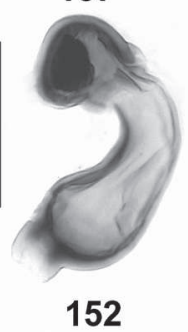

Figs 145-165: Drusilla spiniventris (145-147), D. breviuter (148-152), Pheidologitonetes biplicatus (153-154), Zyras conlectus (155157), Z. hetzeli (158-159), Z. reductus (160-162), and Z. shavrini (163-165): male tergite VIII (145, 148); median lobe of aedeagus in lateral and in ventral view (146-147, 149-150, 153-156, 158-161, 163-164); female tergite VIII (151); spermatheca (152); paramere $(157,162,165)$. Scale bars: 145-151, 153-165: $0.2 \mathrm{~mm}$; 152: $0.1 \mathrm{~mm}$. 


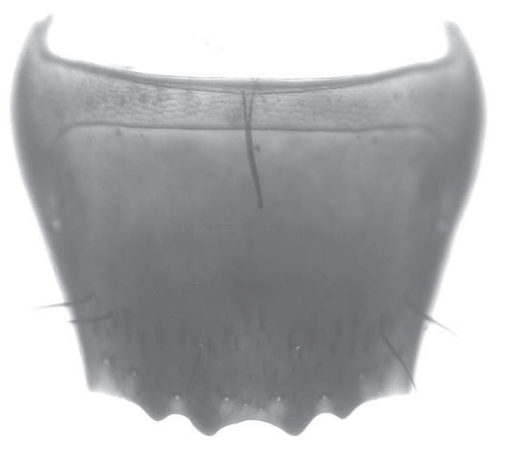

166

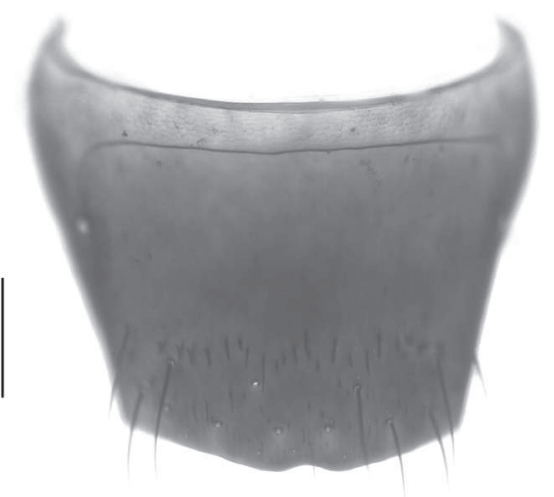

168
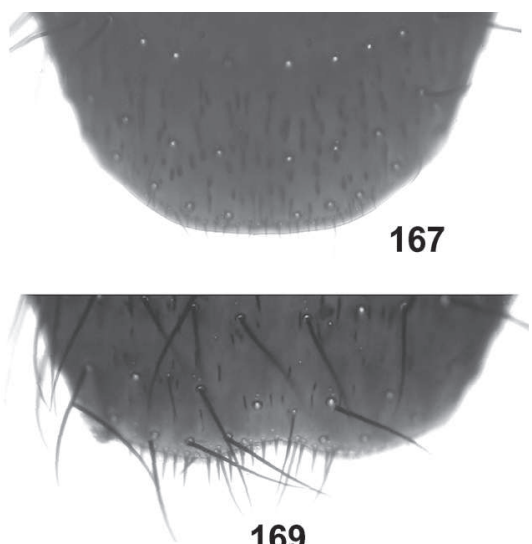

169

Figs 166-169: Zyras conlectus: male tergite VIII (166); posterior portion of male sternite VIII (167); female tergite VIII (168); posterior portion of female sternite VIII (169). Scale bar: $0.2 \mathrm{~mm}$.

\section{Orphnebius gibber Assing, 2006}

Material examined: China: 1 ㅇ, Sichuan, pass between Yanyuan and Muli, $27.69^{\circ} \mathrm{N}, 101.22^{\circ} \mathrm{E}, 3240 \mathrm{~m}$, 18.VI.2017, leg. Reuter (MMB).

Orphnebius gibber had been reported from Yunnan and Shaanxi. The above female represents the first record from Sichuan.

\section{Orphnebius dishamatus Assing, 2015}

Material examined: China: 57 exs., N-Sichuan, XiaoZhaizi National Nature Reserve, $7 \mathrm{~km}$ W Qingpianxiang, Xiaozhaizi, $32^{\circ} 01^{\prime} \mathrm{N}, 103^{\circ} 56^{\prime} \mathrm{E}, 1560-1700 \mathrm{~m}$, flight interception trap, 27.VI.-1.VII.2017, leg. Kabátek et al. (MMB, cAss).

Previously, only the unique holotype from Yunnan was known (Assing 2015a).

\section{Orphnebius fortesetosus spec. nov. urn:Isid:zoobank.org:act:CEE40705-FCE7-47A3-859A-614E2D7ADCAC (Figs 6-7, 31, 87-90)}

Type material: Holotype $\sigma^{*}$ : "CHINA N Sichuan, Xiao-Zhaizi National Nature Reserve, $7 \mathrm{~km}$ W of Qingpianxiang, $1560-1700 \mathrm{~m}$, Xiaozhaizi, 27.6.-1.7.2017, FIT, $32^{\circ} 1$ '25"N 10356'21"E, lgt. P. Kabátek, O. Konvička, P. Viktora / Holotypus ơ Orphnebius fortesetosus sp. n., det. V. Assing 2017” (SCS). $28 \sigma^{\top} \sigma^{\top}$ : same data as holotype (MMB, cAss).

Etymology: The specific epithet is an adjective composed of the Latin adjectives fortis (strong) and setosus (with setae). It alludes to the stout setae on the paramere.

Description: Body length $3.5-4.3 \mathrm{~mm}$; length of forebody $1.4-1.6 \mathrm{~mm}$. Coloration (Figs 6-7): forebody blackish with the humeral portions of the elytra more or less distinctly and more or less extensively yellowish; abdomen reddish, sometimes with the median portions of tergites V-VII slightly and diffusely darker; legs red, usually with the mesofemora somewhat darker; antennae (Fig. 31) with antennomeres I-IV yellowish-red, V palereddish to reddish-brown, and VI-XI black; maxillary palpi yellowish-red.

Head (Fig. 6) approximately 1.3 times as broad as long, posterior angles completely obsolete; punctation extremely fine, barely visible, and very sparse; median dorsal portion impunctate; interstices without microsculpture. Eyes very large, longer than distance from posterior margin of eye to posterior constriction of head. Antenna (Fig. 31) approximately $1.0 \mathrm{~mm}$ long, moderately incrassate, and weakly asymmetric; antennomeres IV-X somewhat flattened or oval in cross-section; antennomere IV small and moderately transverse; antennomere $\mathrm{V}$ distinctly larger than IV and more distinctly transverse; antennomeres VI-X of gradually increasing width and increasingly transverse; $\mathrm{X}$ more than twice as broad as long; XI elongate, approximately as long as the combined length of VII-X.

Pronotum (Fig. 6) 1.30-1.35 times as broad as long and 1.25-1.30 times as broad as head, moderately convex in cross-section; posterior angles practically obsolete; disc impunctate; lateral margins each with five long and stout black setae, anterior margin with an additional long seta on either side.

Elytra (Fig. 6) approximately $0.8-0.9$ times as long as pronotum; suture distinctly gaping posteriorly; punctation sparse and fine. Hind wings fully developed. Metatarsomere I approximately as long as the combined length of II and III.

Abdomen (Fig. 7) broad, gradually tapering from base towards apex; tergites III-VI with fine setiferous punctures at posterior margins and with a long dark seta in postero-lateral portions, otherwise practically impunctate; tergite VII with dense and somewhat oblong non-setiferous punctures in posterior $3 / 5$, posterior margin with distinct palisade fringe; tergite VIII with a 
marginal and a submarginal row of long setae, posterior margin broadly convex.

$0^{*}$ : hemi-tergites IX and tergite $\mathrm{X}$ with dense and long pubescence; median lobe of aedeagus (Figs 87-88) $0.75-0.80 \mathrm{~mm}$ long; ventral process relatively short and of subtriangular shape in ventral view; paramere (Figs 89-90) $0.5 \mathrm{~mm}$ long, paramerite with four stout setae subapically; condylite stout and slightly shorter than paramerite.

o: unknown.

Comparative notes: As can be inferred from external and particularly the male primary and sexual characters, O.fortesetosus belongs to the O.hauseri subgroup of the O.hauseri group. For an overview of the species currently assigned to this group see Assing (2017a). The species is distinguished from other representatives of this subgroup recorded from China particularly by the coloration of the elytra (all other Chinese species of the O. hauseri subgroup have the elytra uniformly blackish) and by the morphology of the aedeagus, in particular the four stout subapical setae of the paramere.

Distribution and natural history: The type locality is situated in Xiao-Zhaizi National Nature Reserve (China: North Sichuan). The specimes were collected with a flight interception trap at an altitude of 1560-1700 m. Remarkably, all 29 specimens are males.

\section{Orphnebius biscuspis Assing, 2016}

Material examined: India: 4 exs., Arunachal Pradesh, Etalin env., $28^{\circ} 37^{\prime} \mathrm{N}, 95^{\circ} 53^{\prime} \mathrm{E}, 700 \mathrm{~m}, 12-25 . \mathrm{V} .2102$, leg. Šauša (MMB, cAss).

Based on the shape of the spermatheca, on the bifid ventral process of the aedeagus, on the slender paramerite, and on the large head, this species belongs to the $O$. dilatatus subgroup of the $O$. hauseri group (see Assing 2016b). The above specimens were collected close to the locality where some of the paratypes were found.

\section{Orphnebius uniformis PACE, 2007}

Material examined: Malaysia: Sarawak: $10^{\top}, 1$, , Gunung National Park, 2011, leg. Hanski (cRou, cAss).

The above specimens represent the first record since the original description, which is based on one male and seven females from two localities in Sabah, Borneo (PACE 2007).
Orphnebius taurus spec. nov.

urn:Isid:zoobank.org:act:9C47DCE3-7D9A-4D71-8A4B-24036B41A66D

(Figs 3-5, 91-95)

Type material: Holotype ơ: "SW Cambodia, $20 \mathrm{~km} \mathrm{SE}$ Koh Kong, 50-300 m, 3.-19.v.2005, Tatai river, $11^{\circ} 34^{\prime} \mathrm{N}$, $103^{\circ} 07^{\prime}$ E, E. Jendek \& O. Šauša leg. / Holotypus $\sigma^{*}$ Orphnebius taurus sp. n., det. V. Assing 2018" (MMB).

Etymology: The specific epithet (Latin: bull) is a noun in apposition and alludes to the two long horn-shaped processes of the mandibles.

Description: Small species; body length $3.0 \mathrm{~mm}$; length of forebody $1.4 \mathrm{~mm}$. Habitus as in Fig. 3. Coloration: head blackish with the anterior portion brown; pronotum pitchy-black; elytra yellowish-brown with the scutellar portion diffusely darker; abdomen pale yellowish-brown; legs yellowish-brown with dark-yellowish tarsi; antennae dark-brown with antennomeres II-V reddish; maxillary palpi brown with the apical palpomere yellow.

Head (Figs 4-5) strongly transverse, in the middle of dorsal surface with pronounced tubercle-shaped elevation; both mandibles with a long and erect horn-shaped process originating from their bases (male secondary sexual character?). Eyes very large, longer than distance from posterior margin of eye to posterior constriction of head. Antenna approximately $1.0 \mathrm{~mm}$ long, distinctly incrassate apically, and somewhat clavate, with antennomeres VI-X much larger than antennomeres II-V; antennomere I large, long, and distinctly compressed, nearly as long as the combined length of antennomeres II-V; antennomeres VI-X strongly transverse and distinctly asymmetric; antennomere XI approximately as long as the combined length of antennomeres VIII-X. Pronotum strongly transverse and rather small in relation to head, approximately 1.65 times as broad as long and approximately as broad as head, moderately convex in cross-section; posterior angles obsolete; disc impunctate; lateral margins each with three long and stout darkbrown setae.

Elytra approximately 0.8 times as long as pronotum, strongly widened posteriad; punctation sparse and fine. Hind wings fully developed. Metatarsomere I approximately as long as the combined length of II and III.

Abdomen broad, gradually tapering from base towards apex; segments III-VI with broad and dorsally truncate paratergites; tergites III-VI practically impunctate; tergite VII with dense and long striae except near anterior margin; tergite VIII laterally with a cluster of dense thin setae on either side, posterior margin broadly convex.

$0^{*}$ : hemi-tergites IX and tergite X with dense and long pubescence; sternite VIII as in Fig. 91; median lobe of aedeagus (Figs 92-94) $0.65 \mathrm{~mm}$ long and of distinctive shape; ventral process apically acute and conspicuously structured; paramere (Fig. 95) $0.57 \mathrm{~mm}$ long, paramerite very slender.

\%: unknown. 
Comparative notes: Based on the large head (in relation to the pronotum) and the slender paramerite, O. taurus is assigned to the $O$. dilatatus subgroup of the O. hauseri group. Among the species of the O. hauseri group, the new species is characterized particularly by the conspicuous modifications of the (male?) head (median tubercle; two long mandibular processes) and by the shape of the median lobe of the aedeagus.

Distribution and natural history: The type locality is situated near Koh Kong in Southwest Cambodia at an altitude between 50 and $300 \mathrm{~m}$. Additional data are not available.

\section{Orphnebius (Deroleptus) multimpressus Assing, 2015}

Material examined: China: Yunnan: 1 ex. [teneral], Xishuangbanna, $20 \mathrm{~km}$ NW Jinghong, Man Dian env., $22^{\circ} 08^{\prime} \mathrm{N}, 100^{\circ} 40^{\prime} \mathrm{E}, 740 \mathrm{~m}$, rubber plantation, malaise trap, 20.X.2008, leg. Weigel (NME); 1 ex., 26 km NW Jinghong, An Man Xin Zhai, $22^{\circ} 11^{\prime} \mathrm{N}, 100^{\circ} 38^{\prime} \mathrm{E}, 760 \mathrm{~m}$, forest, malaise trap, 30.X.2008, leg. Meng (NME); 2 exs., Xishuangbanna, $23 \mathrm{~km} \mathrm{NW}$ Jinghong, $\mathrm{Na}$ Ban, $22^{\circ} 10^{\prime} \mathrm{N}$, $100^{\circ} 40^{\prime} \mathrm{E}, 730 \mathrm{~m}$, malaise trap, 30.X.2008, leg. Weigel (NMW, cAss); 1 ex., same data, but rubber plantation, pitfall trap, 10.X.2008 (NMW); 2 exs., same data, but 20.X.2008, leg. Weigel (NME); 1 ex., Xishuangbanna, $37 \mathrm{~km}$ NW Jinghong, Guo Men Shan, $22^{\circ} 14^{\prime} \mathrm{N}, 100^{\circ} 36^{\prime} \mathrm{E}$, $1080 \mathrm{~m}$, open land, malaise trap, 18.VII.2008, leg. Meng (cAss). Taiwan: $1 \sigma^{\star}$, Nantou, Lu-Shan Hot Spring, $24^{\circ} 01^{\prime} \mathrm{N}, 121^{\circ} 12^{\prime} \mathrm{E}, 1340 \mathrm{~m}$, coniferous forest, litter sifted, 25.VII.2018, leg. Hetzel (cFel).

This species was previously known only from Yunnan (Assing 2017a). The above male from Taiwan represents the first record from this island.

\section{Orphnebius (Deroleptus) niger (CAMERON, 1939)}

Material examined: India: 3 exs. [ 1 teneral], West Bengal, Kalimpong (Lower Tanek), $27.06^{\circ} \mathrm{N}, 88.44^{\circ} \mathrm{E}, 625 \mathrm{~m}$, 1-11.XII.2013, leg. Tomkovich (cKov, cAss).

Orphnebius niger had been reported from the Northeast Indian provinces Assam and Meghalaya (Assing 2017a). The specimens represent the first record from West Bengal.

\section{Orphnebius (Deroleptus) spoliatus Assing, 2016}

Material examined: China: 116 exs., N-Sichuan, XiaoZhaizi National Nature Reserve, $7 \mathrm{~km}$ W Qingpianxiang, Xiaozhaizi, $32^{\circ} 01^{\prime} \mathrm{N}, 103^{\circ} 56^{\prime} \mathrm{E}, 1560-1700 \mathrm{~m}$, flight interception trap, 27.VI.-1.VII.2017, leg. Kabátek et al. (MMB, cAss).
The original description is based on 16 specimens from the type locality in Northeast Laos (Assing 2016b). The material from Sichuan is distinguished from the type specimens by significantly darker coloration. In the material from Sichuan, the legs are more or less uniformly yellowish, the basal three antennomeres are yellowishred to reddish, and the humeral portions of the elytra are more or less distinctly and more or less extensively yellowish, whereas in the type material the profemora and the apical halves of the meso- and metafemora are blackish, the tibiae are brown to blackish-brown, the antennae are more or less uniformly blackish with antennomeres II and III slightly paler at most, and the elytra are uniformly blackish. No significant differences were found, however, in the shapes of the primary sexual characters, suggesting that the populations from Sichuan and Laos are conspecific and that the observed pronounced differences are an expression of remarkable intraspecific variation of coloration.

The specimens from Sichuan represent the first record of this species from China.

\section{Orphnebius (Deroleptus) cultellatus Assing, 2016}

Material examined: China: Yunnan: 1 ex., $26 \mathrm{~km}$ NW Jinghong, An Man Xin Zhai, $22^{\circ} 11^{\prime} \mathrm{N}, 100^{\circ} 38^{\prime} \mathrm{E}, 760 \mathrm{~m}$, forest, malaise trap, 10.X.2008, leg. Meng (NME); 1 ex., same data, but 30.X.2008 (cAss).

The known distribution of this widespread species includes the Chinese province Yunnan, Thailand, Laos, and Borneo (Assing 2017a).

\section{Orphnebius (Deroleptus) dispar Assing, 2016}

Material examined: India: 3 exs., Arunachal Pradesh, Etalin env., $28^{\circ} 37^{\prime} \mathrm{N}, 95^{\circ} 53^{\prime} \mathrm{E}, 700 \mathrm{~m}, 12-25 . \mathrm{V} .2102$, leg. Šauša (MMB, cAss).

The above specimens were collected at the type locality.

\section{Orphnebius (Deroleptus) vates Assing, 2016}

Material examined: Laos: $10^{\top}$ [aedeagus missing], Khammouane prov., Nakai env., $17^{\circ} 34^{\prime} \mathrm{N}, 105^{\circ} 10^{\prime} \mathrm{E}, 500 \mathrm{~m}$, 14-18.IV.2017, leg. Hergovits (MMB).

The original description is based on a unique male holotype from Phongsaly province, Laos. 
Orphnebius (Deroleptus) grootaerti PACE, 2004 (Figs 96-100)

Material examined: Laos: $10^{\star}, 2$ ㅇ ㅇ , Khammouane prov., Nakai env., $17^{\circ} 34^{\prime} \mathrm{N}, 105^{\circ} 10^{\prime} \mathrm{E}, 500$ m, 14-18.IV.2017, leg. Hergovits (MMB, cAss).

This species was previously known only from the type locality in Thailand. Tergite VIII, the median lobe of the aedeagus, and the spermatheca are illustrated in Figs 96-100.

\section{Orphnebius (Deroleptus) morulus spec. nov.} urn:Isid:zoobank.org:act:DF080E64-CDBB-4BE4-A7CF-D71EA3A270AC (Figs 8-9, 32, 101-105

Type material: Holotype ơ: "S VIETNAM: Lâm Dông Prov., Lac Durong Distr., Bidoup Nuiba Natl Park, surr. Giang Ly Ranger Station (1420-1460 m a.s.l.) 16-21. VI.2015 / legit L. Bartolozzi, G. Chelazzi, S. Bambi, F. Fabiano, E. Orbach, V. Sbordoni (n. Magazzino 3023) / Holotypus o Orphnebius morulus sp. n., det. V. Assing 2017" [collected during expeditions in Vietnam in the framework of a Memorandum of Unterstanding between VNMN and Museo di Zoologia, Università di Firenze] (VNMN).

Etymology: The specific epithet (Latin, adjective: black) alludes to the uniformly black coloration of the body.

Description: Body length $5.2 \mathrm{~mm}$; length of forebody $2.2 \mathrm{~mm}$. Coloration (Figs 8-9, 32): body uniformly black; legs black with reddish tarsi; antennae blackishbrown with black antennomere I; maxillary palpi with palpomeres II brown, III black, and IV yellowish.

Head (Fig. 8) nearly 1.3 times as broad as long, posterior angles convex, moderately marked; dorsal surface with scattered and very fine punctation, median dorsal portion extensively impunctate; interstices without microsculpture. Eyes large, occupying anterior two-thirds of lateral margins of head. Antenna (Fig. 32) slender and weakly incrassate, approximately $1.5 \mathrm{~mm}$ long; antennomeres IV very weakly oblong, $\mathrm{V}-\mathrm{X}$ weakly transverse and gradually increasing in width, $\mathrm{X}$ less than 1.5 times as broad as long, and XI approximately as long as the combined length of IX and X.

Pronotum (Fig. 8) of transversely quadrangular shape, 1.3 times as broad as long and approximately as broad as head; moderately strongly convex in cross-section; lateral margins straight in dorsal view; punctation extremely fine and sparse, midline broadly impunctate.

Elytra (Fig. 8) slightly longer and distinctly broader than pronotum; disc somewhat uneven, somewhat elevated anteriorly and shallowly impressed postero-laterally; punctation rather sparse, somewhat asperate (elevated) anteriorly and finer posteriorly; interstices near posterior margin with shallow isodiametric microreticulation, otherwise without microsculpture and very glossy. Hind wings present. Legs very long and slender; metatibia nearly $1.1 \mathrm{~mm}$ long and weakly curved; metatarsus as long as metatibia; metatarsomere I approximately as long as the combined length of III and IV.

Abdomen (Fig. 9) approximately as broad as elytra; anterior sternites without distinct postero-lateral extensions or processes; tergites III-V with few extremely fine setiferous punctures at posterior margins, otherwise impunctate; tergite VI with a lateral setiferous puncture on either side and with four distinct setiferous punctures at posterior margin; tergite VII with dense non-setiferous punctures in posterior two-thirds, anterior portion of this punctate area with numerous longitudinal rugae, at posterior margin with four setiferous punctures, posterior margin with palisade fringe; tergite VIII (Fig. 101) with moderately dense microsetae anteriorly and laterally, anteriorly with sparse gland openings not arranged in clusters, posterior margin truncately produced in the middle and distinctly crenulate, postero-lateral margins with numerous stout dark setae.

$\sigma^{\star}$ : sternite VIII (Fig. 102) with posterior margin truncately produced in the middle, laterally and posteriorly with setae; median lobe of aedeagus $0.6 \mathrm{~mm}$ long and shaped as in Figs 103-104; paramere (Fig. 105) $0.45 \mathrm{~mm}$ long, apical lobe moderately long and apically convex. ㅇ: unknown.

Comparative notes: Based on the external and sexual characters, O. morulus belongs to the O. siwalikensis group (see Assing 2016b, 2017a). Among the species of this group, it is characterized by the black body, black femora and tibiae, long and slender legs and antennae, the punctation and microsculpture of the uneven elytra (see above), the derived shapes and chaetotaxy of tergite and sternite VIII, and the shapes of the median lobe and the parameres of the aedeagus. It is readily distinguished from O. willersi PACE, 2001, the sole representative of the O. siwalikensis group previously recorded from Vietnam, by much darker coloration alone. For illustrations of O. willersi see Assing (2015).

Distribution and natural history: The type locality is situated at about $12^{\circ} 08^{\prime} \mathrm{N}, 108^{\circ} 32^{\prime} \mathrm{E}$ in South Vietnam, at an altitude of approximately $1450 \mathrm{~m}$.

\section{Orphnebius (Deroleptus) globifer spec. nov. urn:Isid:zoobank.org:act:F2AB5418-A6A3-4125-AB1B-5B6C18EEF85E (Figs 10-11, 34, 106-108)}

Type material: Holotype o : "MALAYSIA 2011 PAHANG, Cameron Highlands, Tanah Rata vill. env., 1500-1600 m, FIT, R. Hergovits leg. 4.iv.2011 / Holotypus o Orphnebius globifer sp. n., det. V. Assing 2017” (MMB).

Etymology: The specific epithet (Latin, adjective) alludes to the globulous proximal portion of the spermatheca. 
Description: Body length $5.7 \mathrm{~mm}$; length of forebody $2.3 \mathrm{~mm}$. Coloration (Figs 10-11, 34): head black; pronotum reddish-brown; scutellum dark-yellow; elytra dark-brown; abdomen reddish with segment VII extensively infuscate; legs reddish-brown; antennae reddish; maxillary palpi yellowish-red.

Head (Fig. 10) nearly 1.5 times as broad as long, posterior angles convex, moderately marked; clypeus membranous, anterior margin of sclerotized portion (frons?) strongly concave; dorsal surface with sparse and very fine punctation, median dorsal portion extensively impunctate; interstices without microsculpture. Eyes large, occupying anterior four-fifths of lateral margins of head. Antenna (Fig. 34) not particularly slender, $1.75 \mathrm{~mm}$ long; antennomeres III rather stout, flattened, and not distinctly constricted basally, IV-X moderately transverse, only slightly increasing in width, $\mathrm{X}$ approximately 1.5 times as broad as long, and XI somewhat longer than the combined length of IX and X.

Pronotum (Fig. 10) of transversely trapezoid shape, broadest anteriorly, approximately 1.4 times as broad as long and approximately 0.9 times as broad as head; disc rather strongly convex in cross-section; lateral margins straight in dorsal view, converging posteriad; punctation extremely fine and sparse, midline broadly impunctate.

Elytra (Fig. 10) approximately 1.2 times as long as, and distinctly broader than pronotum; punctation fine and rather sparse, very sparse in postero-sutural portions; interstices without microsculpture and very glossy. Hind wings fully developed. Legs long and slender; metatibia $1.1 \mathrm{~mm}$ long; metatarsus nearly as long as metatibia; metatarsomere I slightly longer than the combined length of II and III.

Abdomen (Fig. 11) gradually tapering from base to apex; anterior sternites without distinct postero-lateral extensions or processes; tergites III-VI with scattered micropunctation, otherwise impunctate; tergite VI with few fine setae at posterior margin; tergite VII extensively with dense non-setiferous punctures, except near anterior and posterior margins, near posterior margin with approximately $10-12$ setae inserting in small tubercles, posterior margin with palisade fringe; tergite VIII (Fig. 106) anteriorly with two extensive clusters of dense gland openings, posterior margin nearly truncate and distinctly crenulate.

$o^{*}$ : unknown.

\%: sternite VIII (Fig. 107) transverse, postero-laterally with clusters of stout setae; posterior margin truncate; spermatheca (Fig. 108) of distinctive shape.

Comparative notes: Based on the external and sexual characters, O. globifer clearly belongs to the O. siwalikensis group, too. Among the species of this group, it is characterized by the coloration, the morphology of the antennae, the absence of processes on the anterior sternites, and particularly by the conspicuous shape of the spermatheca. For illustrations of numerous species of the O. siwalikensis group see Assing (2016b, 2017a), for a catalogue of the species currently assigned to this group see Assing (2017a).

Distribution and natural history: The type locality is situated in Cameron Highlands (Peninsular Malaysia: Pahang). The holotype was collected with a flight interception trap at an altitude of 1500-1600 m.

\section{Orphnebius (Deroleptus) elevatus spec. nov. urn:lsid:zoobank.org:act:839D7EBF-6AD4-420B-97A1-8448D1F5036B (Figs 12-15, 16, 33, 109)}

Type material: Holotype + : "LAOS, Khammouane prov., Nakai env., $14-18 . i v .2017,17^{\circ} 34^{\prime} \mathrm{N}, 105^{\circ} 10^{\prime} \mathrm{E}, 500 \mathrm{~m}$, A. \& R. Hergovits lgt. / Holotypus o Orphnebius elevatus sp. n., det. V. Assing 2017" (MMB).

Etymology: The specific epithet is the past participle of the Latin verb elevare and alludes to the presence of long elevations on either side of the elytral suture.

Description: Body length $4.8 \mathrm{~mm}$; length of forebody $2.0 \mathrm{~mm}$. Coloration (Figs 12-13, 16, 33): head blackish-brown; pronotum reddish; elytra reddish with the postero-lateral portions slightly and diffusely darker; abdomen reddish with segment VII blackish-brown; legs yellowish-red; antennae reddish; maxillary palpi yellowish with palpomere III slightly darker.

Head (Figs 12-13) nearly 1.5 times as broad as long, posterior angles obsolete; clypeus not membranous, truncate anteriorly; dorsal surface with sparse and fine punctation, median dorsal portion extensively impunctate; interstices without microsculpture. Eyes large and bulging, nearly reaching posterior margin of head. Antenna (Fig. 33) not particularly slender, $1.4 \mathrm{~mm}$ long; antennomeres III slender, IV approximately as long as broad, V-X weakly transverse, only slightly increasing in width, $\mathrm{X}$ much less than 1.5 times as broad as long, and XI approximately as long as the combined length of IX and X.

Pronotum (Figs 12-13) of transversely trapezoid shape, broadest anteriorly, approximately 1.5 times as broad as long and approximately 0.9 times as broad as head; disc rather strongly convex in cross-section; lateral margins straight in dorsal view, converging posteriad; punctation extremely fine and sparse, midline broadly impunctate.

Elytra (Figs 12-13) approximately 1.2 times as long as, and distinctly broader than pronotum; on either side of suture with an oblong elevation; punctation fine and rather sparse; interstices without microsculpture and very glossy. Hind wings fully developed. Legs long and slender; metatibia approximately $1.0 \mathrm{~mm}$ long; metatarsus nearly as long as metatibia; metatarsomere I slightly longer than the combined length of II and III.

Abdomen (Fig. 16) gradually tapering from base to apex; sternite IV and paratergites IV each with a horizontal postero-lateral extension, the sternal and the paratergal extension contiguous (Fig. 14); tergites III- 
VI practically impunctate, except for a pair of tubercles near posterior margin of tergite VI each bearing a long dark seta; tergite VII (Fig. 15) with dense and extensive non-setiferous punctation, these punctures separated by longitudinal ridges anteriorly, near posterior margin with approximately 10 small setiferous tubercles, posterior margin with palisade fringe; tergite VIII (Fig. 15) in posterior portion with dark setae inserting in distinct tubercles, posterior margin strongly concave and with pronounced tubercles rendering the margin serrate.

$o^{*}$ : unknown.

ㅇ: sternite VIII with convex posterior margin; spermatheca (Fig. 109) of distinctive shape.

Comparative notes: Like O. globifer, O. elevatus belongs to the O. siwalikensis group. In coloration, habitus, and the modifications of the abdominal segment IV, O. elevatus is most similar to O. baccillatus Assing, 2016, whose original description is based on a unique female holotype from Laos. The new species is distinguished from O. baccillatus by shorter and more slender (i.e., finer) antennae, smaller body size (O. baccillatus: body length $6.2 \mathrm{~mm}$; length of forebody $2.5 \mathrm{~mm}$ ), the presence of elevations on either side of the elytral suture, the shorter extension of sternite IV, the longer extension of paratergites IV (in relation to the extension of sternite IV), the pair of setiferous tubercles near the posterior margin of tergite VI, the more strongly concave posterior margin of tergite VIII, and above all by the completely different shape of the spermatheca. For illustrations of O. baccillatus and numerous other species of the O. siwalikensis group see Assing (2016b).

Distribution and natural history: The type locality is situated in Khammouane province, Laos, at an altitude of $500 \mathrm{~m}$. Additional data are not available.

\section{Orphnebius (Deroleptus) moruliflavus spec. nov.} urn:Isid:zoobank.org:act:57A6C5B3-7F8A-46BB-88B3-2213C17C91A8 (Figs 17-18, 110-113)

Type material: Holotype ơ: "BORNEO, Sabah, ca. 300 m, SAFE Project xi-xii.2011, Logged forest, Palm oil,

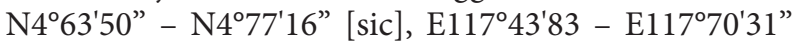
[sic], Malaise-Pitfall Combination / SAFE Project, Ewers et al., 111119-154b, 016004 / Holotypus o Orphnebius moruliflavus sp. n., det. V. Assing 2018” (cAss).

Etymology: The specific epithet is an adjective composed of the Latin adjectives morulus (black) and flavus (yellow). It alludes to the conspicuously bicoloured body.

Description: Body length $3.6 \mathrm{~mm}$; length of forebody $1.6 \mathrm{~mm}$. Habitus as in Fig. 17. Coloration (Figs 17-18): head blackish with the frons and the clypeus paler brown; remainder of body dark-yellow; legs, antennae, and maxillary palpi yellow.
Head strongly transverse, posterior angles obsolete; clypeus not membranous, broadly concave anteriorly; dorsal surface with moderately sparse and moderately fine punctation; interstices without microsculpture. Eyes large and bulging, nearly reaching posterior margin of head. Antenna moderately slender, $1.4 \mathrm{~mm}$ long; antennomeres III slender, IV weakly oblong, V approximately as long as broad, VI-X increasingly transverse and gradually increasing in width, $\mathrm{X}$ less than 1.5 times as broad as long, and XI approximately as long as the combined length of IX and X.

Pronotum strongly transverse, 1.65 times as broad as long and as broad as head; disc moderately convex in cross-section; lateral margins straight and nearly parallel in dorsal view; punctation fine and sparse, midline broadly impunctate; lateral margins each with three long and erect black setae, two anteriorly and one posteriorly.

Elytra approximately 1.2 times as long as, and distinctly broader than pronotum; punctation moderately fine and moderately dense; interstices without microsculpture. Hind wings fully developed. Legs moderately long and slender; metatibia approximately $0.7 \mathrm{~mm}$ long; metatarsus nearly as long as metatibia; metatarsomere I slightly longer than the combined length of II and III.

Abdomen (Fig. 18) gradually tapering from base to apex; tergite IV and sternites III-IV with a short and broadly rounded extension; sternite $\mathrm{V}$ with a pronounced, long and flattened extension directed posteriad; tergite IV broadly and convexly produced posteriorly; tergite $\mathrm{V}$ broadly produced posteriorly, middle of this projection broadly truncate; tergites V and VI with a pair of moderately long setae at posterior margin and with a conspicuously stout long and dark seta postero-laterally on either side; tergites III-VI otherwise practically impunctate; tergite VII with rather coarse and very dense non-setiferous punctation, posterior margin with a pronounced palisade fringe; tergite VIII with posterior margin of distinctive shape (Fig. 110).

$\sigma^{\star}$ : sternite VIII transverse, with strongly convex posterior margin, and with some stout dark setae mediolaterally; median lobe of aedeagus and paramere as in Figs 111-113.

ㅇ: unknown.

Comparative notes: Based on the external and sexual characters, especially the shape of tergite VIII and the chaetotaxy of sternite VIII, O. moruliflavus belongs to the O. siwalikensis group. Among the species of this group, it is characterized particularly by the coloration, the modifications of the abdomen, and the shape of the posterior margin of tergite VIII. From other species of the O. siwalikensis group recorded from Borneo, this species is distinguished by the coloration alone. For illustrations of numerous other species of the O. siwalikensis group see Assing (2016b, 2017a). 
Distribution and natural history: The type locality is situated in Sabah (Malaysia), Borneo. The holotype was collected with a combination of Malaise and pitfall traps.

\subsection{Genus Keratodegnathus PACE, 2014}

\section{Keratodegnathus cornutus spec. nov.}

urn:Isid:zoobank.org:act:042656C4-9410-4A3A-9648-037977E13C0C

(Figs 19-23, 114-117)

Type material: Holotype ơ: "MALAYSIA 2011 PAHANG, Cameron Highlands, Tanah Rata vill. env., 1500-1600 m, FIT, R. Hergovits leg. 4.iv.2011 / Holotypus o Keratodegnathus cornutus sp. n., det. V. Assing 2017” (MMB). Paratype + : same data as holotype (cAss).

Etymology: The specific epithet (Latin, adjective) alludes to the horn-like processes of the mandibles.

Description: Body length 6.0-6.6 mm; length of forebody 2.8-3.3 mm. Coloration (Figs 19-23): forebody black, except for the yellowish scutellum; abdomen palereddish; legs blackish-brown to black with slightly paler tarsi; antennae distinctly bicoloured, black with antennomeres X and XI pale-yellowish; maxillary palpi reddish. Head (Figs 19-20) strongly transverse, sexually dimorphic; posterior margin concave in dorsal view; clypeus membranous; frons and vertex without punctation, without pubescence, and without microsculpture. Eyes large and strongly convex in cross-section, more than twice as long as postocular region in dorsal view. Antenna (Fig. 22) conspicuously elongate, $3.8-4.0 \mathrm{~mm}$ long; antennomeres IV-IX approximately three times as long as broad, X 2.5 times as long as broad, and XI five times as long as broad. Maxillary palpi slender, palpomere IV approximately four times as long as broad. Mandibles sexually dimorphic, with conspicuous horn-shaped processes dorsally.

Pronotum (Figs 19-20) of transversely trapezoid shape, broader anteriorly than posteriorly, 1.41-1.45 times as broad as long and 0.85-0.90 times as broad as head; lateral margins distinctly sinuate in dorsal view; disc with a transverse series of 4 punctures at anterior fourth and a pair of punctures in the middle, otherwise impunctate; lateral margins each with four very long and erect black setae; microsculpture absent.

Elytra (Figs 19-20) slightly longer and distinctly broader than pronotum; punctation fine and very sparse; interstices without microsculpture. Hind wings fully developed. Legs very long and slender; metatarsus nearly as long as metatibia; metatarsomere I nearly as long as the combined length of metatarsomeres II-IV.

Abdomen (Fig. 23) tapering from base to apex; tergite III with one, tergites IV-VII with two long black setae on either side, otherwise without setae; tergite VI with two additional setae in median portion of posterior margin; non-setiferous punctation absent; posterior margin of tergite VII with palisade fringe; tergite VIII with approximately 10-12 long black setae in posterior portion, posterior margin convex, not sexually dimorphic.

$0^{\top}$ : head (Figs 19, 21) large, strongly transverse, with strongly concave posterior margin (dorsal view), distinctly impressed between eyes, and shallowly impressed in antero-lateral portion of frons; mandibles each with a conspicuous bifurcate antler-shaped process, these processes with ventral branch directed nearly horizontally forward and with a dorsal, nearly vertically upright branch; median lobe of aedeagus $0.7 \mathrm{~mm}$ long and shaped as in Figs 114-115; paramere (Fig. 116) nearly as long as median lobe, without conspicuous modification.

o : head (Fig. 20) smaller and less transverse than in male, with more weakly concave posterior margin (dorsal view), less distinctly impressed between eyes, but with a marked impression in antero-lateral portion of frons on either side; mandibles each with one simple, curved, apically acute, and sub-erect process (shaped like a second set of mandibles); spermatheca (Fig. 117) with numerous thin coils, a small distal portion, and with a large balloonshaped structure.

Comparative notes: Previously, only two species of Keratodegnathus PACE, 2014 were known, both of them described from Sabah, Borneo, K. rougemonti PACE, 2014 (type species) and K. mirabilis PACE, 2014. While K. mirabilis is of completely different external morphology (e.g., with short antennae with strongly transverse antennomeres $\mathrm{V}-\mathrm{X}$ ) suggesting that it belongs to Orphnebius, $K$. rougemonti resembles $K$. cornutus in many ways (habitus, coloration of a antennae, shape of median lobe of aedeagus). The new species is distinguished from $K$. rougemonti by completely different coloration (K. rougemonti: forebody reddish; legs yellow) and apparently also by the shape of the spermatheca. Note, however, that the spermatheca figured by PACE (2014) is clearly incomplete.

Distribution and natural history: The type locality is situated in Cameron Highlands (Peninsular Malaysia: Pahang). The specimens were collected with a flight interception trap at an altitude of 1500-1600 m.

\subsection{Genus Amaurodera FAuveL, 1905}

The distribution of Amaurodera is confined to the southern East Palaearctic and Oriental regions, where it was previously represented by 53 species (Assing 2017a). The three species newly described below raise this figure to 56 . The latest catalogue was provided by Assing (2016b). 
Amaurodera fulgens Assing, 2003

Material examined: Nepal: 6 exs., Kathmandu, south slope of Mt. Shivapuri, $27^{\circ} 49^{\prime} \mathrm{N}, 85^{\circ} 23^{\prime} \mathrm{E}, 2400-2500 \mathrm{~m}$, 2.VI.2016, leg. Schmidt (NME, cAss).

This species has been recorded only from Central Nepal (Assing 2016b).

\section{Amaurodera verrucosa Assing, 2003}

Material examined: Nepal: 6 exs., Taplejung, W above Gurja, $27^{\circ} 9^{\prime} \mathrm{N}, 87^{\circ} 33^{\prime} \mathrm{E}, 2100-2500 \mathrm{~m}, 23 .-24 . V .2016$, leg. Schmidt (NME, cAss).

The distribution of $A$. verrucosa is confined to East Nepal (Assing 2016b).

\section{Amaurodera soror CAMERON, 1939}

Material examined: India: $1 \sigma^{\star}$, Uttarakhand Rishikesh, Ganga river, $30.11^{\circ} \mathrm{N}, 78.31^{\circ} \mathrm{E}, 12-13 . \mathrm{IV} .2012$, leg. Tomkovich (cAss).

This species is widespread in the Himalaya.

\section{Amaurodera schmidti spec. nov. urn:Isid:zoobank.org:act:7ABC3A7D-5EA4-47C5-90A5-F8F451BF1914 (Figs 24-26, 118-121)}

Type material: Holotype ơ: "E-NEPAL, D: SankhuwaSaba, N of Chauki, 27.V.2016, 2600-2700 m, 27012'52"N, $87^{\circ} 27^{\prime} 47^{\prime \prime E}$, leg. J. Schmidt / Holotypus o Amaurodera schmidti sp. n., det. V. Assing 2017" (NME). Paratypes: 12 exs.: same data as holotype (NME, cAss).

Etymology: This species is dedicated to Joachim Schmidt, Rostock, who collected the type series and whose numerous field trips to Nepal have significantly contributed to our current knowledge of the Staphylinidae fauna of the Himalaya.

Description: Body length 5.5-6.5 mm; length of forebody $2.6-2.9 \mathrm{~mm}$. Other measurements: head width: $0.8 \mathrm{~mm}$; length of pronotum: $1.2 \mathrm{~mm}$; width of pronotum: $0.8 \mathrm{~mm}$; elytral width: $0.95-1.00 \mathrm{~mm}$. Coloration: forebody blackish; abdomen with tergites III-IV reddish to reddish-brown, $\mathrm{V}$ blackish with reddish margins, VI-VII blackish with reddish posterior margins, and VIII with the anterior portion dark-brown and the posterior portion dark-yellowish; legs yellowish with the profemora and the apical halves of the meso- and metafemora darker; antennae reddish-brown to blackish-brown with antennomeres I-II and the basal portion of III pale-reddish and often also XI reddish; maxillary palpi dark-yellowish to yellowish-brown.

Head (Figs 24-25) weakly oblong; postero-lateral outline between eyes and posterior constriction broadly convex in dorsal view; median dorsal portion not impressed; punctation fine and rather sparse; interstices with (particularly in posterior dorsal portion) or without shallow microreticulation. Eyes distinctly convex, approximately half as long as distance from posterior margin of eye to posterior constriction. Antenna (Fig. 26) elongate, 2.9-3.0 mm long; antennomere $\mathrm{X}$ noticeably oblong.

Pronotum (Fig. 24) approximately 1.5 times as long as broad and as broad as head, without sexual dimorphism; dorsal surface opaque due to very dense microgranules; midline with long and narrow sulcus reaching neither anterior nor posterior margins; antero-laterally with sparse short setae on either side.

Elytra (Fig. 24) conspicuously short, approximately 0.4 times as long as pronotum; punctation fine and rather sparse; interstices with very shallow, nearly obsolete microreticulation. Hind wings reduced. Metatarsomere I nearly as long as the combined length of II-IV.

Abdomen broader than elytra; tergites III-V with moderately deep anterior impressions; punctation fine and very sparse; interstices with very shallow microsculpture; posterior margin of tergite VII with palisade fringe; posterior margin of tergite VIII crenulate.

$\mathrm{o}^{\star}$ : posterior margin of sternite VIII in the middle with convex projection; median lobe of aedeagus 0.68 $0.70 \mathrm{~mm}$ long and shaped as in Figs 120-121.

\% : posterior margin of sternite VIII broadly convex; spermatheca shaped as in Figs 118-119.

Comparative notes: Based on external (large size, dark coloration, long and slender antennae and legs, absence of a sexual dimorphism of the pronotum) and the primary sexual characters (large and broad median lobe of the aedeagus; S-shaped and proximally not distinctly truncate spermatheca), A. schmidti belongs to the A. silvana group (Assing 2003). It is distinguished from other representatives of this group known from East Nepal by the shape of the aedeagus and additionally as follows: from A. granata Assing, 2003 by distinctly sparser punctation of the elytra and a spermatheca with a larger cuticular invagination;

from A. fulgens Assing, 2003 by a distinctly bicoloured abdomen and by the paler coloration of the legs and antennae (A. fulgens: abdomen blackish; legs and antennae dark-brown to blackish);

from A. kleebergi Assing, 2006 by sparser punctation of the elytra, a bicoloured abdomen, and by paler legs and antennae (A. kleebergi: abdomen, legs, and antennae blackish);

from A. arunica Assing, 2016 by sparser punctation of the elytra, a distinctly bicoloured abdomen, and paler basal antennomeres (A. arunica: abdomen dark-brown to blackish with the anterior segments indistinctly paler at most; basal antennomeres blackish-brown to black). 
For illustrations of A. granata, A. fulgens, A. kleebergi, and A. arunica see Assing (2003, 2006, 2016b).

Distribution and natural history: The type locality is situated to the north of Chauki (East Nepal: SankhuwaSaba District) at an altitude of 2600-2700 m.

\section{Amaurodera calicitheca Assing, 2017}

Material examined: Malaysia: 1 , Sabah, $4.63-4.77^{\circ} \mathrm{N}$, $117.44-117.70^{\circ} \mathrm{E}, 300 \mathrm{~m}$, logged forest, Malaise-pitfall combination, XI-XII.2011, leg. Ewers et al. (cRou).

The original description is based on 12 type specimens from two localities in Sabah.

\section{Amaurodera brevipennis spec. nov. urn:Isid:zoobank.org:act:5AB88702-0D52-4B1F-A7AA-0654B71DC14F (Figs 27-28, 122-123)}

Type material: Holotype ơ: "BORNEO, Sabah, ca. 300 m, SAFE Project, xi.-xii.2011, Logged forest, Palm oil,

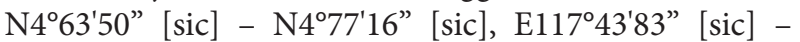
E117\%70'31" [sic], Malaise-Pitfall Combination / SAFE Project, Ewers et al., 111113-227b, 020512 / Holotypus ○ Amaurodera brevipennis sp. n., det. V. Assing 2017” (cRou).

Etymology: The specific epithet (Latin, adjective) alludes to the conspicuously short elytra.

Description: Small species; body length $3.7 \mathrm{~mm}$; length of forebody $1.7 \mathrm{~mm}$. Other measurements: head width: $0.48 \mathrm{~mm}$; length of pronotum: $0.74 \mathrm{~mm}$; width of pronotum: $0.54 \mathrm{~mm}$; elytral length at suture: $0.27 \mathrm{~mm}$; elytral width: $0.42 \mathrm{~mm}$. Coloration: head and pronotum reddish; elytra pale-reddish with the postero-lateral portions extensively, diffusely darker; abdomen palereddish with segment VI and the posterior margin of segment $\mathrm{V}$ blackish; legs: profemora and protibiae pale-brown, meso- and metafemora blackish with the basal portions yellowish, meso- and metatibia and tarsi yellowish; antennae with antennomeres I-II reddish, III-V dark-brown, VI-IX gradually becoming paler, and $\mathrm{X}$-XI yellow; maxillary palpi reddish with the terminal palpomere pale-yellowish.

Head (Fig. 27) weakly oblong; postero-lateral outline between eyes and posterior constriction broadly convex in dorsal view; median dorsal portion not impressed; median and anterior dorsal portions extensively without punctation, lateral and posterior portions of dorsal surface with very fine and sparse punctures; interstices without distinct microreticulation. Eyes rather small, weakly convex, approximately 0.6 times as long as distance from posterior margin of eye to posterior constriction. Antenna (Fig. 28) conspicuously elongate,
$2.3 \mathrm{~mm}$ long; antennomeres IX and X twice and 1.5 times as long as broad, respectively.

Pronotum (Fig. 27) 1.37 times as long as broad and approximately 1.1 times as broad as head; dorsal surface opaque due to very dense microgranules; midline with long and narrow sulcus reaching neither anterior nor posterior margins; antero-laterally with two long and erect setae on either side.

Elytra (Fig. 27) conspicuously short, 0.36 times as long as pronotum; punctation very fine and very sparse; interstices without distinct microreticulation. Hind wings probably reduced. Metatarsomere I shorter than the combined length of II and III.

Abdomen distinctly broader than elytra; tergites III-V with moderately deep anterior impressions; punctation fine and sparse; interstices with microsculpture; posterior margin of tergite VII with narrow palisade fringe; posterior margin of tergite VIII crenulate.

$\sigma^{*}$ : posterior margin of sternite VIII in the middle broadly and weakly convex; median lobe of aedeagus $0.36 \mathrm{~mm}$ long and shaped as in Figs 122-123.

o: : unknown.

Comparative notes: The only other Amaurodera species with similarly short elytra is the geographically close A. kinabaluensis PACE, 1989 (Sabah: Mt. Kinabalu), which is distinguished from A. brevipennis by smaller eyes, a larger head (in relation to the pronotum), even shorter and posteriorly distinctly dilated elytra, and by the different shape of the median lobe of the aedeagus. For illustrations of A. kinabaluensis see PACE (1989).

Distribution and natural history: The type locality is situated in Sabah (Malaysia: Borneo) at an altitude of $300 \mathrm{~m}$. The coordinates are evidently incorrect, as can be inferred from the observation that the minutes and seconds are partly greater than 59 .

\section{Amaurodera atra spec. nov. urn:Isid:zoobank.org:act:7D5CCE81-D9AF-4599-B7C0-AA4D6D0AD8C2 (Figs 29-30, 124-128)}

Type material: Holotype o : "PHILIPPINES - Mindanao, Mt. Hamiguitan Wildlife Sanctuary, Banakon creek, $6.74^{\circ} \mathrm{N}, 126.15^{\circ} \mathrm{E}, 400 \mathrm{~m}$, wet litter \& debris sifted, 22-24.III.2018, leg. Shavrin / Holotypus o ${ }^{\star}$ Amaurodera atra sp. n., det. V. Assing 2018" (cAss). Paratypes: $10^{\star}, 4$ ㅇ ㅇ: same data as holotype (cAss); $40^{\star \star} o^{\star}, 2$ ㅇ 우 "PHILIPPINES: Mindanao, Sitio Bitaugan, Kawa-kawa River, 300 m, 6 $46^{\prime} 31^{\prime \prime} \mathrm{N}, 126^{\circ} 08^{\prime} 41^{\prime \prime E}$, stream bank, wet litter, debris, dead wood, 24-26.III.2018, leg. Shavrin" (cAss).

Etymology: The specific epithet (Latin, adjective) alludes to the uniformly black coloration of the body, a character distinguishing this species from the congeners previously recorded from the Philippines. 
Description: Body length 3.9-4.9 mm; length of forebody 2.0-2.4 mm. Habitus as in Fig. 29. Other measurements: head width: $0.8 \mathrm{~mm}$; length of pronotum: $0.75-0.85 \mathrm{~mm}$; width of pronotum: $0.55-0.60 \mathrm{~mm}$; elytral width: $0.75-$ $0.85 \mathrm{~mm}$. Coloration: whole body black, except for the yellowish-brown abdominal segments IX-X and the posterior margin of segment VIII; legs distinctly bicoloured with the profemora and most of the meso- and metafemora blackish and with the tibiae, tarsi, and the bases of the meso- and metafemora yellowish; antennae blackish-brown to blackish with the basal two antennomeres usually somewhat paler brown and with the apical 3-5 antennomeres dark-yellow; maxillary palpi darkbrown with the apical palpomere pale-yellowish.

Head (Fig. 30) weakly transverse; dorsal surface with or without shallow isodiametric microsculpture; punctation very fine and rather sparse. Eyes distinctly convex, approximately as long as distance from posterior margin of eye to posterior constriction. Antenna $2.0-2.1 \mathrm{~mm}$ long; antennomere IV approximately twice as long as broad; antennomeres $\mathrm{V}-\mathrm{X}$ gradually decreasing in length and decreasingly oblong, $\mathrm{X}$ weakly oblong.

Pronotum (Fig. 30 ) approximately 1.25 times as long as broad and as broad as head, without sexual dimorphism; dorsal surface opaque due to very dense microgranules; midline with narrow sulcus reaching neither anterior nor posterior margins; antero-laterally with sparse short setae on either side.

Elytra (Fig. 30) approximately 0.6 times as long as pronotum; punctation fine and rather dense; interstices without microreticulation, except near anterior margins. Hind wings present. Metatarsomere I shorter than the combined length of II-IV.

Abdomen narrower than elytra; tergites III-V with rather shallow anterior impressions; punctation fine and sparse; tergites V-VII with very shallow transverse microsculpture, tergites III-IV with more distinct transverse or oblique microsculpture, tergite VIII with pronounced microsculpture composed of short transverse meshes; posterior margin of tergite VII with palisade fringe; posterior margin of tergite VIII crenulate.

$\sigma^{*}$ : posterior margin of sternite VIII strongly convex; median lobe of aedeagus $0.53-0.58 \mathrm{~mm}$ long and shaped as in Figs 124-125.

$\%$ : posterior margin of sternite VIII broadly convex; spermatheca (Figs 126-128) with distinctly dilated proximal and distal portions and with slender median portion.

Comparative notes: Two species of Amaurodera were previously known from the Philippines, A. philippina CAMERon, 1941 (primary sexual characters unknown) from Siargao Island and A. orousseti PACE, 1990 from Luzon (Assing 2016b). The new species is distinguished from them as follows:

from A. philippina by larger body size (A. philippina: body length $3.2 \mathrm{~mm}$ ) and by the coloration (A. philippina: pronotum brown; elytra brownish-yellow; abdomen with segments III-V reddish and segments VIII and the posterior margin of VII yellow; antennae and legs reddish-yellow);

from $A$. orousseti by larger body size (A. orousseti: body length $4.0 \mathrm{~mm}$ ), the coloration (A. orousseti: body brownish-red with brown pronotum; legs yellowish-red with the femora and the protibiae brown; antennae darkred with antennomeres I-II and XI reddish), by the shape of the aedeagus (A. orousseti: ventral process apically more acute in ventral view), and by the shape of the spermatheca (A. orousseti: proximal and distal portions less strongly dilated; median portion less slender; distal cuticular invagination acute). For illustrations of the primary sexual characters of A. orousseti see PACE (1990).

Amaurodera atra differs from the widespread and variable A. kraepelini FAUvel, 1905 by the primary sexual characters, particularly the shape of the spermatheca (A. kraepelini: distal portion weakly dilated; proximal portion more strongly dilated).

Distribution and natural history: The type specimens were collected in two geographically close localities in the southeast of Mindanao, Philippines, by sifting wet litter and debris near running water at altitudes of 300 and $400 \mathrm{~m}$.

\subsection{Genus Drusilla LEACH, 1819}

\section{Drusilla cernens Assing, 2005}

Material examined: Lebanon: $1 \sigma^{\star}, 2$ 우 우, Marjayoun env., Litani river, $33.357^{\circ} \mathrm{N}, 35.547^{\circ} \mathrm{E}, 280 \mathrm{~m}$, pitfall traps, 18.XI.-11.XII.2017, leg. Reuter (cFel, cAss).

Drusilla cernens was previously known only from Israel and Syria. The above specimens represent the first record from Lebanon.

\section{Drusilla obliqua (BERNHAUER, 1916)}

Drusilla zyrasoides Dvořák, 1988, syn. nov.

Material examined: Vietnam: 23 exs., Hoa Binh Province, Pa Co Hang Kia Nature Reserve, 900 m, at light, 5-7.VI.2013, leg. Bartolozzi et al. (MSNF, cAss).

The type material of D. zyrasoides was examined by Assing (2015c). It is conspecific with D. obliqua.

\section{Drusilla mixta CAMERON, 1939}

Material examined: India: $1 \sigma^{\star}$, Uttarakhand, Timlishera, $30.311^{\circ} \mathrm{N}, 78.342^{\circ} \mathrm{E}, 1040 \mathrm{~m}, 3-5 . \mathrm{V} .2012$, leg. Tomkovich (cAss).

This species has been recorded only from Uttarakhand. 


\section{Drusilla yunnanensis PACE, 1993}

Material examined: China: Yunnan: $1 \sigma^{\star}$, NE Kunming, $25^{\circ} 09^{\prime} \mathrm{N}, 102^{\circ} 54^{\prime} \mathrm{E}, 2280 \mathrm{~m}$, secondary pine forest, with scattered old alder, litter sifted, 11.VIII.2014, leg. Schülke (MNB); $1 \sigma^{\star}$, NE Kunming, $25^{\circ} 09^{\prime} \mathrm{N}, 102^{\circ} 54^{\prime} \mathrm{E}, 2290 \mathrm{~m}$, mixed deciduous forest with scattered pine trees, litter and mushrooms sifted, 11.VIII.2014, leg. Schülke (cAss).

This species is widespread in China. For a map and illustrations of external and sexual characters see Assing (2015b).

\section{Drusilla perdensa PACE, 2004}

Material examined: China: Yunnan: 5 우, Yunnan, Tengchong, Laifeng Forest Park, $25^{\circ} 01^{\prime} \mathrm{N}, 98^{\circ} 29^{\prime} \mathrm{E}, 1730-$ 1910 m, mixed tropical forest, 22.VI.2016, leg. Hájek \& Růžička (NMP, cAss).

Originally described from Thailand, this species was already reported from Yunnan by Assing (2017a).

\section{Drusilla bispinosa spec. nov.}

urn:Isid:zoobank.org:act:A3E4F51F-809D-407F-9DE0-5655A67106AC (Figs 35-43, 129-131)

Type material: Holotype ơ: "MALAYSIA 2011 PAHANG, Cameron Highlands, Tanah Rata vill. env., 1500-1600 m, FIT, R. Hergovits leg. 4.iv.2011 / Holotypus o Drusilla bispinosa sp. n., det. V. Assing 2017" (MMB). Paratypes: 27 exs.: same data as holotype (MMB, cAss).

Etymology: The specific epithet (Latin, adjective) alludes to the presence of two pronounced spines on the male abdominal tergite III.

Description: Large species; body length $6.7-9.3 \mathrm{~mm}$; length of forebody $3.3-4.0 \mathrm{~mm}$. Coloration: forebody blackish-brown to blackish; abdomen blackish-brown, with segments II-V often reddish to reddish-brown; legs yellow; antennae blackish-brown to black with antennomere II usually reddish to reddish-brown; maxillary palpi pale-brown to brown with the apical palpomere yellow. Head (Fig. 35) transverse, 1.15-1.20 times as broad as long; punctation fine and rather dense; interstices with fine microreticulation. Eyes large, much longer than distance from posterior margin of eye to posterior constriction in dorsal view. Antenna (Fig. 36) elongate and slender, approximately $3.5 \mathrm{~mm}$ long; antennomeres IV-X all approximately twice as long as broad.

Pronotum (Fig. 35) slender, 1.05-1.16 times as long as broad and 1.01-1.10 times as broad as head, broadest in anterior half; sexual dimorphism weakly pronounced; along midline with sharp and narrow sulcus; lateral margins strongly sinuate in dorsal view; posterior angles pronounced; punctation dense and distinct, regularly distributed; interstices on average slightly narrower than diameter of punctures and with shallow microreticulation visible only at high magnification.

Elytra (Fig. 35) 0.80-0.85 times as long as pronotum; laterally with a sharp carina on either side; punctation and microsculpture similar to that of pronotum. Hind wings fully developed. Legs slender; metatarsomere I nearly as long as the combined length of II-IV.

Abdomen (Fig. 37) narrower than elytra; tergite III with pronounced sexual dimorphism; tergites II-III with numerous punctures; tergites IV-VII with few scattered punctures anteriorly, on discs, and at posterior margins, as well as with scattered micropunctation, otherwise impunctate; all tergites with shallow and fine transverse microsculpture; tergite VII sexually dimorphic, posterior margin with palisade fringe; tergite VIII sexually dimorphic.

$0^{*}$ : pronotum somewhat depressed on either side of the median sulcus and near posterior angles; abdominal tergite III (Figs 38-39) with a pronounced spine of variable shape on either side; tergite VII (Figs 40-42) with a median tubercle or a median carinae posteriorly; tergite VIII (Figs 40-42) with a pronounced median tubercle posteriorly, posterior margin concave and conspicuously angled laterally; median lobe of aedeagus approximately $0.9 \mathrm{~mm}$ long and shaped as in Figs 129-130.

\%: tergites III and VII unmodified; posterior margin of tergite VIII produced and with three tooth-like projections (Fig. 43); spermatheca as in Fig. 131.

Comparative notes: This distinctive species is characterized particularly by the slender habitus and large body size, by the distinctive modifications of the male tergites III and VII, by the shapes of the male and female tergite VIII, and by the primary sexual characters.

Distribution and natural history: The type locality is situated in Pahang Province, Peninsular Malaysia. The specimens were collected with a flight interception trap at an altitude of $1500-1600 \mathrm{~m}$.

\section{Drusilla shavrini spec. nov. urn:Isid:zoobank.org:act:7EF756D2-6CFE-4230-AAF4-298C3D1B76BE (Figs 44-47, 132-139)}

Type material: Holotype $\sigma^{*}$ : "PHILIPPINES: Mindanao, Sitio Bitaugan, Kawa-kawa River, 300 m, 646'31"N, $126^{\circ} 08^{\prime} 41^{\prime} E$, stream bank, wet litter, debris, dead wood, 24-26.III.2018, leg. Shavrin / Holotypus o Drusilla shavrini sp. n., det. V. Assing 2018” (cAss). Paratypes: $4 \sigma^{\top} \sigma^{\star}, 6$ ㅇ 우 [partly slightly teneral]: same data as holotype; $20^{\star} \sigma^{\star}$ [1 teneral], 1 \%: "PHILIPPINES - Mindanao, Mt. Hamiguitan Wildlife Sanctuary, Banakon creek, $6.74^{\circ} \mathrm{N}, 126.15^{\circ} \mathrm{E}, 400 \mathrm{~m}$, wet litter \& debris sifted, $22-24$. III.2018, leg. Shavrin” (cAss). 
Etymology: This species is dedicated to Alexey Shavrin (Daugavpils), the collector of the type series.

Description: Body length $4.3-5.2 \mathrm{~mm}$; length of forebody $2.0-2.2 \mathrm{~mm}$. Habitus as in Fig. 44. Coloration: head and pronotum black; elytra dark-yellowish to yellowish-brown with the postero-lateral portion extensively black, sometimes leaving only the sutural and anterior portions paler; abdomen black with the anterior margins of tergites and paratergites III-V yellowish; legs pale-yellow with the profemora, the apical three-fifths of the mesofemora, and the apical half of the metafemora black, protibiae sometimes somewhat infuscate; antennae blackish-brown with the basal two antennomeres slightly paler; maxillary palpi yellow to dark-brown with the apical palpomere yellow.

Head (Fig. 45) transverse, approximately 1.15 times as broad as long; punctation very fine and very sparse; interstices without microreticulation. Eyes large, approximately three times as long as distance from posterior margin of eye to posterior constriction in dorsal view. Antenna (Fig. 46) $1.8-2.0 \mathrm{~mm}$ long and rather massive; antennomeres IV weakly oblong, $\mathrm{V}$ approximately as long as broad, VI-X weakly transverse, X much less than 1.5 times as broad as long, and XI approximately as long as the combined length of IX and X.

Pronotum (Fig. 45) without sexual dimorphism, strongly convex in cross-section, weakly transverse, 1.031.05 times as broad as long and approximately as broad as head, broadest at anterior angles; along midline with sharp and narrow sulcus posteriorly terminating in a deep impression; lateral margins weakly sinuate in dorsal view; posterior angles obtusely marked; punctation dense and distinct; interstices without microsculpture.

Elytra (Fig. 45) approximately 0.65 times as long as pronotum, strongly transverse (width combined); punctation very dense and rather coarse; interstices reduced to narrow ridges, without microsculpture. Hind wings fully developed. Metatarsomere I approximately as long as the combined length of III and IV.

Abdomen (Fig. 47) narrower than elytra; tergite III with sparse and very fine setiferous punctation; tergites IV-VII with very sparse and extremely fine punctation, median portions of these tergites largely impunctate; tergites III-VI with or without very shallow traces of transverse microsculpture; tergite VII with shallow microsculpture composed of transverse meshes, posterior margin with palisade fringe; tergite VIII with microsculpture composed of transverse meshes.

$0^{*}$ : tergite VIII (Fig. 132) with broadly and weakly concave, nearly truncate posterior margin, in anterior portion with numerous gland openings; sternite VIII (Fig. 133) much longer than tergite VIII, with convex posterior margin, in anterior portion with numerous gland openings; median lobe of aedeagus approximately $0.8 \mathrm{~mm}$ long and shaped as in Figs 134-135; ventral process apically abruptly narrowed in ventral view; parameres approximately $0.7 \mathrm{~mm}$ long. $q$ : tergite VIII (Fig. 136) with sparse gland openings anteriorly, posterior margin truncate; sternite VIII (Fig. 137) with sparse gland openings anteriorly, posterior margin broadly convex; spermatheca as in Figs 138-139.

Comparative notes: Eight species of Drusilla were previously known from the Philippines: D. bernhaueri (SCHEERPELTZ, 1934) [replacement name for D. luzonica (Bernhauer, 1927)] from Luzon; D. butuanensis (BerNHAUER, 1916) from Mindanao; D. impressicollis (KraAtz, 1857) (originally described from Sri Lanka); D. laevicauda (BernhaUer, 1903) (originally described from Sumatra); D. luzonica (Bernhauer, 1915) from Luzon; D. philippina (Bernhauer, 1915) from Luzon; D. plicipennis (Bernhauer, 1915) from Luzon; D. schawalleri Kistner, 1994 from Leyte (Huaváč et al. 2011). Except for D. schawalleri, the primary sexual characters are unknown. Drusilla shavrini is distinguished from all these species as follows:

from $D$. bernhaueri by the coloration (D. bernhaueri: body yellow with infuscate head), larger size (D. bernhaueri: body length slightly more than $3 \mathrm{~mm}$, the shape of the head (D. bernhaueri: posterior angles acutely produced), much less transverse antennomeres $\mathrm{V}-\mathrm{X}$ (approximately 1.5 times as broad as long in D. bernhaueri), the absence of lateral impressions on the pronotum, the punctation of the pronotum and the elytra (granulose in D. bernhaueri), and the (near) absence of microsculpture on the anterior abdominal tergites;

from D. butuanensis by the coloration (D. butuanensis: head and pronotum reddish; elytra brownish-yellow with brown lateral and posterior margins; legs pale-yellow), larger body size (D. butuanensis: $3 \mathrm{~mm}$ ), extremely fine punctation of the head, less transverse antennomeres $\mathrm{V}-\mathrm{X}$, the absence of a deep median impression on the male pronotum, denser punctation of the pronotum and elytra, the absence of a carina in the anterior portion of the male elytra, unmodified male tergites V-VII, and the shape of the posterior margin of tergite VIII (D. butuanensis: deeply and angularly excised);

from $D$. impressicollis by the coloration (D. impressicollis: pronotum brown; legs reddish-yellow), larger size (D. impressicollis: $3 \mathrm{~mm}$ ), a broader head in relation to the pronotum (D. impressicollis: head much narrower than pronotum), the shape of the pronotum (D. impressicollis: pronotum distinctly transverse), the absence of a sexual dimorphism of the pronotum (D. impressicollis: male pronotum with broad impression in posterior half and with granulose punctation), and the shape of the posterior margin of the male tergite VIII (denticulate in D. impressicollis);

from D. laevicauda by the coloration (D. laevicauda: pronotum and elytra brown; paratergites $\mathrm{V}$ yellow; legs yellow), larger body size (D. laevicauda: $3 \mathrm{~mm}$ ), and the shape of the pronotum (with subparallel lateral margins in D. laevicauda);

from $D$. luzonica by the coloration (D. luzonica: antennae reddish; elytra yellowish-brown; legs yellow), the absence 
of lateral impressions on the pronotum, and shorter elytra;

from $D$. philippina by the coloration (D. philippina: antennae reddish; elytra yellowish-brown, in humeral portions extensively yellow) and larger size (D. philippina: $3 \mathrm{~mm}$ ); from $D$. plicipennis by the coloration (D. plicipennis: head and pronotum reddish; elytra brownish-yellow with brown lateral and posterior margins; legs pale-yellow), larger body size (D. plicipennis: $3 \mathrm{~mm}$ ), extremely fine punctation of the head, less transverse antennomeres $\mathrm{V}-\mathrm{X}$, the absence of a deep median impression on the male pronotum, the absence of a carina in the anterior portion of the male elytra, unmodified male tergites IIIVII, and the shape of the posterior margin of tergite VIII (D. plicipennis: deeply and angularly excised);

from D. schawalleri by the coloration (D. schawalleri: legs and antennae uniformly reddish-brown), much more massive antennae (D. schawalleri: all antennomeres slender and distinctly oblong), and by the completely different primary sexual characters; for illustrations of D. schawalleri see KISTNER (1994).

Several species from other regions have primary sexual characters of a similar type. Drusilla shavrini is distinguished from them as follows:

from D. perforans Assing, 2015 (North Vietnam) by different coloration, shorter, less slender, and more massive antennae, a transverse pronotum with indistinctly sinuate lateral margins and without a sexual dimorphism, and different sexual characters (for illustrations see Assing 2015c);

from D. takashii Maruyama, 2004 (Laos) by the coloration (D. takashii: legs black with the apices of the tibiae and the tarsi reddish-brown), much larger eyes, less slender antennae (D. takashii: all antennomeres oblong), less dense punctation and pubescence of the forebody, and by the primary sexual characters; for illustrations see Maruyama (2004);

from $D$. dimidiata PACE, 1987 (Sulawesi; female unknown) by larger body size (D. dimidiata: $3.2 \mathrm{~mm}$ ), the coloration (D. dimidiata: body brown; antennae dark-reddish with dark-yellowish basal antennomeres; legs yellowish with the apices of the meso- and metafemora slightly infuscate apically), and much larger eyes; for illustrations see PACE (1987);

from D. pervisa PACE, 1987 (Java; male unknown) by the coloration (D. pervisa: body brown; legs yellow with brownish knees; antennae brown with the basal three antennomeres yellow);

from D. truncatella PACE, 2004 (Malaysia: Pahang; male unknown) by completely different coloration and by the sexual characters, particularly the shape of the female sternite VIII; for illustrations see PACE (2004);

from D. damingensis PACE, 2012 (China) by the coloration (D. damingensis: head and pronotum brown; legs yellowish-red with the apical half or apical third of the femora reddish-brown), much more massive, less slender antennae (D. damingensis: all antennomeres oblong), much larger eyes, the shape of the head (concave in
D. damingensis), the shape of the male tergite III (posterior margin crenulate and concave in $D$. damingensis); for illustrations see PACE (2012).

Distribution and natural history: The type specimens were collected in two geographically close localities in the southeast of Mindanao, Philippines, by sifting wet litter and debris near running water at altitudes of 300 and $400 \mathrm{~m}$. Some of the type specimens are more or less distinctly teneral.

\section{Drusilla penicillata spec. nov. urn:Isid:zoobank.org:act:CAA17FAD-AE2A-496C-9D08-84D34358BDD5 (Figs 48-52, 140-144)}

Type material: Holotype ơ: "PHILIPPINES: Mindanao, Barangay Baganihan, Marilog D., Epol Falls, $7^{\circ} 27^{\prime} \mathrm{N}$, $125^{\circ} 14^{\prime} \mathrm{E}$, wet litter and debris near waterfall sift., 27.III.2018, leg. Shavrin / Holotypus ơ Drusilla penicillata sp. n., det. V. Assing 2018" (cAss). Paratypes: $1 \sigma^{*}$, 1 ㅇ: same data as holotype; $10^{\circ}$ : "PHILIPPINES: Mindanao, Barangay Baganihan, Marilog D., Eagles Ridge, $7^{\circ} 45^{\prime} \mathrm{N}, 125^{\circ} 23^{\prime} \mathrm{E}$, secondary forest, wet litter sifted, 26-28.III.2018, leg. Shavrin" (cAss).

Etymology: The specific epithet is an adjective derived from the Latin noun penicillus (brush) and alludes to the presence of a setiferous tubercle on the male head.

Description: Relatively large species: body length 5.8-6.7 mm; length of forebody $2.8-3.0 \mathrm{~mm}$. Habitus as in Fig. 48. Coloration: body pale-reddish with the posterior portions of paratergites III-VI weakly infuscate; legs with the tarsi reddish, the bases of the meso- and metafemora and all of the meso- and metatibiae yellow, and the femora (except for the bases of the meso- and metafemora) and the protibae pale-brown; antennae and maxillary palpi pale-reddish.

Head (Fig. 49) sexually dimorphic, transverse, 1.051.10 times as broad as long; punctation very fine and moderately sparse, punctures bearing long sub-erect to depressed setae directed mediad; median dorsal portion extensively impunctate; interstices without microreticulation. Eyes moderately large, approximately 1.5 times as long as distance from posterior margin of eye to posterior constriction in dorsal view. Antenna (Fig. 51) $2.9 \mathrm{~mm}$ long and slender; antennomeres IV-X oblong, IV twice as long as broad, $\mathrm{V}-\mathrm{X}$ decreasingly oblong, $\mathrm{X}$ weakly oblong, and XI shorter than the combined length of IX and $\mathrm{X}$.

Pronotum (Fig. 49) without sexual dimorphism, strongly convex in cross-section, approximately as broad as long and slightly broader than head, broadest at anterior angles; along midline with sharp and narrow sulcus posteriorly terminating in a deep impression; lateral margins indistinctly sinuate in dorsal view; posterior angles obtusely marked; punctation dense and distinct; 
with several long black setae in lateral portions; interstices without microsculpture.

Elytra (Fig. 49) approximately 0.8 times as long as pronotum, strongly transverse (width combined); punctation very dense, coarse, and somewhat asperate, denser near scutellum than elsewhere; interstices reduced to narrow ridges, without microsculpture. Hind wings fully developed. Legs very long and slender; metatarsomere I longer than the combined length of III and IV.

Abdomen (Fig. 52) approximately as broad as elytra; tergite III with moderately dense and distinct setiferous punctation; tergite IV with a variable number of setiferous setae at posterior margin and with a transverse row of setiferous setae across middle; tergites V-VII with setiferous punctures at posterior margins and with very sparse punctation elsewhere; tergites III-VI with shallow and very fine transverse microsculpture visible only at high magnification; tergites VII-VIII with shallow microsculpture composed of transverse meshes; posterior margin of tergite VII with palisade fringe.

$0^{\prime}$ : head (Fig. 50) in the middle of dorsal surface with small tubercle bearing approximately 4-5 long pale setae; tergite VIII (Fig. 140) with posterior margin weakly concave in the middle, in anterior portion with numerous gland openings; sternite VIII much longer than tergite VIII, with convex posterior margin, in anterior portion with numerous gland openings; median lobe of aedeagus approximately $0.9 \mathrm{~mm}$ long and shaped as in Figs 141-142; ventral process apically abruptly narrowed in ventral view; parameres approximately $0.8 \mathrm{~mm}$ long.

\%: tergite VIII (Fig. 143) with moderately sparse gland openings anteriorly, posterior margin very weakly concave in the middle, nearly truncate; sternite VIII with moderately sparse gland openings anteriorly, posterior margin broadly convex, in the middle with short modified marginal setae; spermatheca as in Fig. 144.

Comparative notes: As can be inferred from the similar general morphology of the genitalia, D. penicillata belongs to the same species group as D. shavrini. It is distinguished from all other species previously recorded from the Philippines (see the comparative notes in the section on D. shavrini) and the new species described in the present paper by the coloration and larger body size alone. In addition, it is characterized by the brush-like tubercle on the male head and by the shapes of the median lobe of the aedeagus and of the spermatheca. Regarding the coloration and the general morphology of the genitalia, $D$. penicillata somewhat resembles $D$. perforans from Vietnam, from which it differs by larger body size, the coloration of the antennae, legs, elytra, and abdomen (D. perforans: antennomeres III-X infuscate; legs yellow with the apices of the metafemora infuscate; elytra infuscate in postero-lateral portions; abdomen yellow with the posterior portions of paratergites III-VI, the posterior portion of tergite $\mathrm{V}$, most of tergite VI, and the median portion of tergite VII blackish), by the modifications of the male head, by a larger and less slender pronotum without a broad median impression, with weakly sinuate lateral margins, and with much finer and non-granulose punctation, and by the genitalia.

Distribution and natural history: The type specimens were collected in two geographically close localities in the Central Mindanao, Philippines, by sifting wet litter near a waterfall and in a a secondary broad-leaved forest.

\section{Drusilla spiniventris spec. nov. urn:Isid:zoobank.org:act:BB6FBOAD-90DC-457E-90A1-0534A8AE43D6 (Figs 53-58, 145-147)}

Type material: Holotype $0^{*}$ : "PHILIPPINES: Mindanao, Sitio Bitaugan, Kawa-kawa River, $300 \mathrm{~m}, 6^{\circ} 46^{\prime} 31^{\prime \prime N}$, $126^{\circ} 08^{\prime} 41$ "E, stream bank, wet litter, debris, dead wood, 24-26.III.2018, leg. Shavrin / Holotypus ơ Drusilla spiniventris sp. n., det. V. Assing 2018" (cAss). Paratype $0^{\text {* }}$ : same data as holotype (cAss).

Etymology: The specific epithet (adjective) alludes to the conspicuous spine-like process at the posterior margin of the male sternite IV.

Description: Body length 4.2-4.4 mm; length of forebody $1.8-1.9 \mathrm{~mm}$. Habitus as in Fig. 53. Coloration: forebody blackish with the humeral portions of the elytra diffusely paler; abdomen black with the anterior margins of tergites III-V and the anterior halves of paratergites III-V yellow to yellowish-brown; tibiae and tarsi pale yellowish; femora black with the bases of the meso- and metafemora pale yellowish; antennae darkbrown with antennomeres I-II slightly paler brown; maxillary palpi dark-brown with the apical palpomere yellow.

Head (Fig. 54) weakly transverse and wedge-shaped; punctation extremely fine and very sparse; interstices without microreticulation. Eyes rather large, nearly twice as long as distance from posterior margin of eye to posterior constriction in dorsal view. Antenna (Fig. 55) $1.7-1.8 \mathrm{~mm}$ long and moderately massive; antennomeres IV and V distinctly oblong, VI-X weakly oblong, and XI slightly shorter than the combined length of IX and $\mathrm{X}$.

Pronotum (Fig. 54) strongly convex in cross-section, weakly transverse, approximately 1.05 times as broad as long and approximately as broad as head, broadest at anterior angles, distinctly tapering posteriad; along midline with sharp and narrow sulcus posteriorly terminating in a deep impression; lateral margins straight in dorsal view; posterior angles obtusely marked; punctation dense and distinct; interstices without microsculpture.

Elytra (Fig. 54) approximately 0.75 times as long as pronotum, strongly transverse (width combined); punctation very dense and moderately coarse; interstices reduced to narrow ridges, without microsculpture. Hind 
wings not examined. Metatarsomere I longer than the combined length of III and IV.

Abdomen (Fig. 56) broader than elytra; tergite III with sparse and very fine setiferous punctation; tergites IV-VII with very sparse and extremely fine punctation, median portions of these tergites largely impunctate; tergites III-VIII practically without microsculpture, shallow traces of such microsculpture visible only at high magnification $(100 \mathrm{x})$; posterior margin of tergite VII with palisade fringe.

$0^{*}$ : sternite IV (Figs 57-58) in the middle of posterior margin with a process of triangular shape; tergite VIII (Fig. 145) with broadly and weakly concave, nearly truncate posterior margin, in anterior portion with numerous gland openings; sternite VIII distinctly longer than tergite VIII, with convex posterior margin, in anterior portion with numerous gland openings; median lobe of aedeagus approximately $0.55 \mathrm{~mm}$ long and shaped as in Figs 146-147; ventral process sinuate and apically acute in lateral view; parameres approximately $0.45 \mathrm{~mm}$ long.

q: unknown.

Comparative notes: This species is characterized particularly by the modified male sternite IV and the shape of the median lobe of the aedeagus. It additionally differs from the syntopic $D$. shavrini, with which it shares a similar habitus and a similar coloration, by smaller body size, more extensively black meso- and metafemora, more slender antennae with oblong antennomeres $\mathrm{V}-\mathrm{X}$, smaller and less convex eyes, a pronotum with a deeper median sulcus and with straight lateral margins, longer elytra, and even less distinct microsculpture on the posterior tergites. Aside from the male primary and secondary sexual characters, D. spiniventris is distinguished from other species previously recorded from the Philippines by the combination of body size and coloration alone (see comparative notes in the section on D. shavrini).

Distribution and natural history: The type locality is situated in the southeast of Mindanao, Philippines, and identical to that of $D$. shavrini. The specimens were sifted from wet litter, debris, and dead wood near a river at an altitude of $300 \mathrm{~m}$.

\section{Drusilla breviuter spec. nov.}

urn:Isid:zoobank.org:act:43EDA558-1DBF-4861-B73F-F292EF6169C5

(Figs 59-63, 148-152)

Type material: Holotype + : "PHILIPPINES: Mindanao, Davao, Boss Carreon Function Hall, $7^{\circ} 17^{\prime} \mathrm{N}, 125^{\circ} 41^{\prime} \mathrm{E}$, slope near river, litter sifted, 28.III.2018, leg. Shavrin / Holotypus o Drusilla breviuter sp. n., det. V. Assing 2018" (cAss). Paratypes: $10^{\text {t }}$ [teneral], 1 o : same data as holotype (cAss).
Etymology: The specific epithet is a noun in apposition composed of the Latin adjective brevis (short) and the Latin noun uter (hose). It alludes to the small and short spermatheca.

Description: Body length $4.0-4.7 \mathrm{~mm}$; length of forebody 1.8-2.0 mm. Habitus as in Fig. 59. Coloration: head black; pronotum and elytra black with slight bronze hue; abdomen black with segments III-IV and the narrow posterior margin of tergite $\mathrm{V}$ reddish; legs uniformly yellow; antennae blackish-brown with antennomeres I-II dark-reddish and the apex of antennomere XI reddishyellow; maxillary palpi yellow to pale-reddish with the apical palpomere yellow.

Head (Figs 60-61) transverse, approximately 1.15 times as broad as long, without sexual dimorphism; punctation very fine and moderately dense; interstices without microreticulation. Eyes large and strongly convex, approximately twice as long as distance from posterior margin of eye to posterior constriction in dorsal view. Antenna (Fig. 62) $1.5-1.6 \mathrm{~mm}$ long and distinctly incrassate apically; antennomeres IV weakly transverse, V-X of increasing width and increasingly transverse, $\mathrm{X}$ approximately 1.5 times as broad as long, and XI slightly longer than the combined length of IX and X.

Pronotum (Figs 60-61) with moderate sexual dimorphism, weakly convex in cross-section, moderately transverse, approximately 1.1 times as broad as long and approximately as broad as head, broadest near anterior angles, moderately tapering posteriad; along midline with very fine sulcus posteriorly terminating in a small impression; lateral margins straight in dorsal view; posterior angles obtusely marked; punctation dense and distinct; interstices without microsculpture.

Elytra (Figs 60-61) approximately 0.85 times as long as pronotum; punctation similar to that of pronotum, but somewhat denser; interstices without microsculpture. Hind wings fully developed. Metatarsomere I relatively short, barely as long as the combined length of III and IV.

Abdomen (Fig. 63) broad and relatively short, approximately as broad as elytra; tergite III-VII with few punctures at posterior margin, otherwise nearly impunctate; all tergites with shallow and fine transverse microsculpture; posterior margin of tergite VII with palisade fringe.

$\sigma^{*}$ : pronotum (Fig. 60) with rather extensive, but not very deep median impression, posteriorly with a granulose elevation on either side, punctation slightly granulose; tergite VIII (Fig. 148) strongly transverse, posterior margin with a pronounced tooth on either side, in the middle between these teeth with a broadly truncate projection, in anterior portion with few scattered gland openings; sternite VIII strongly transverse, longer than tergite VIII, with strongly convex posterior margin, in anterior portion without gland openings; median lobe of aedeagus $0.43 \mathrm{~mm}$ long and shaped as in Figs 149-150; 
ventral process broad, apically broadly triangular in ventral view.

†: pronotum (Fig. 61) only with shallow oblong impression along middle in posterior portion, without elevation, and with non-granulose punctation; tergite VIII (Fig. 151) strongly transverse, posterior margin with broad and shallow excision laterally delimited by a triangular projection on either side, anterior half with scattered gland openings; sternite VIII strongly transverse, posterior margin convex, with long and thin marginal setae in the middle; spermatheca (Fig. 152) comma-shaped, very small and very short.

Comparative notes: Based on the primary sexual characters, $D$. breviuter is closely allied to D. endopilosella PACE, 2000 from Thailand and D. semimonticola PACE, 2008 (male unknown) from Borneo. It is readily distinguished from both of them by the coloration of the abdomen (completely reddish in the other species) and by the shape of the spermatheca. For illustrations of $D$. endopilosella and D. semimonticola see PACE (2000, 2008). It differs from the widespread and common D. obliqua (Bernhauer, 1916) by numerous characters, e.g., a smaller and more slender body with narrower elytra, the coloration of the abdomen and elytra (D. obliqua: abdomen blackish with the narrow posterior margins of the segments yellow; elytra yellow with the posterolateral portions extensively blackish), much less massive antennae with more transverse antennomeres V-X, the shape of the head (depressed or impressed in D. obliqua), the modifications of the male pronotum, the shapes of the male and female tergite and sternite VIII, and by the completely different primary sexual characters. For illustrations of D. obliqua see Assing (2015b, 2017a).

Distribution and natural history: The type locality is situated to the northeast of Davao, near the coast of the Gulf of Davao, Central Mindanao, Philippines. The specimens were sifted from litter on a slope near a river. The male paratype is distinctly teneral.

\subsection{Genus Rabdotodrusilla PACE, 2013}

This recently described genus includes only three species from Malaysia, Thailand, and Northeast India (Assing 2017a).

\section{Rabdotodrusilla malaysiensis PACE, 2013}

Material examined: Malaysia: Sabah: $20^{\star} o^{\star}, 1$ 우, Sepilok F. R., 13.II.2017, leg. Rougemont (cRou, cAss).

The original description is based on a unique female from Peninsular Malaysia (PACE 2013). The above specimens represent the first record from Borneo.

\subsection{Genus Witteia Maruyama \& von Beeren, 2010}

Witteia currently includes three species from Malaysia, Myanmar, Borneo, and the Chinese province Yunnan (Assing 2017a). In the course of the present study, material of three probably undescribed species from Northeast India was seen. Since each of them is represented by only one sex and by specimens in poor condition, they remain unnamed.

\section{Witteia tensa Assing, 2017}

Material examined: China: Yunnan: 1 ex., Xishuangbanna, $23 \mathrm{~km}$ NW Jinghong, $\mathrm{Na}$ Ban, $22^{\circ} 10^{\prime} \mathrm{N}, 100^{\circ} 40^{\prime} \mathrm{E}$, $680 \mathrm{~m}$, light trap, 17.V.2008, leg. Weigel (NME); 2 exs., same locality data, $730 \mathrm{~m}$, malaise trap, 30.X.2008, leg. Weigel (NME, cAss); 1 ex., Xishuangbanna, 20 km NW Jinghong, Man Dian env., $22^{\circ} 08^{\prime} \mathrm{N}, 100^{\circ} 40^{\prime} \mathrm{E}, 730 \mathrm{~m}$, malaise trap, 20.X.2008, leg. Weigel (NME).

The above material was partly collected together with the types.

\subsection{Genus Pheidologitonetes CAMERON, 1939}

Pheidologitonetes previously comprised four species from South India, Nepal, and Hong Kong, plus two species of doubtful generic assignment from South India (Assing 2017a).

\section{Pheidologitonetes biplicatus spec. nov. urn:Isid:zoobank.org:act:77CC7252-1567-4522-A89E-9B0D5E1C486A (Figs 64-67, 153-154)}

Type material: Holotype ơ: "CHINA: Yunnan [CH0718], Baoshan Pref., mountain range $22 \mathrm{~km} \mathrm{~S}$ Tengchong, $1750 \mathrm{~m}, 24^{\circ} 49^{\prime} 29^{\prime \prime} \mathrm{N}, 98^{\circ} 29^{\prime} 27^{\prime \prime} \mathrm{E}$, second. forest, litter, dead wood sifted, 2.VI.2007, M. Schülke / Holotypus o Pheidologitonetes biplicatus sp. n., det. V. Assing 2018” (MNB).

Etymology: The specific epithet (Latin, adjective) alludes to the pair of pronounced laminae at the base of the ventral process of the aedeagus.

Description: Body length $4.0 \mathrm{~mm}$; length of forebody $1.7 \mathrm{~mm}$. Habitus as in Fig. 64. Coloration: head darkbrown; pronotum reddish-brown; elytra brown with the anterior margins reddish; abdomen reddish-yellow; legs yellow; antennae pale-reddish; maxillary palpi yellow. Head (Fig. 65) transverse, 1.25 times as broad as long; median portion of dorsal surface shallowly impressed; punctation moderately sparse and extremely fine, visible only at high magnification $(100 \mathrm{x})$; interstices glossy despite distinct microreticulation. Eyes large 
and strongly convex, longer than postocular region in dorsal view. Antenna (Fig. 66) elongate and slender, $2.0 \mathrm{~mm}$ long; antennomeres IV-V approximately twice as long as broad, VI-X gradually and slightly decreasing in length and decreasingly oblong, $\mathrm{X}$ approximately 1.5 times as long as broad, XI nearly three times as long as broad and approximately as long as the combined length of IX and X.

Pronotum (Fig. 65) 1.12 times as broad as long and approximately as broad as head, broadest at anterior angles; lateral margins sinuate in dorsal view; posterior angles marked; disc with conspicuous microreticulation and matt. Elytra (Fig. 65) slightly shorter than pronotum; punctation fine and sparse; interstices without microsculpture. Hind wings fully developed. Legs slender; metatarsomere I nearly as long as the combined length of II-IV.

Abdomen (Fig. 67) narrower than elytra; tergites III-V without distinct anterior impressions; tergites III-IV with a median pair of setiferous punctures and with few setiferous punctures at posterior margin and laterally, otherwise impunctate; tergite V-VI with a lateral setiferous puncture on either side and with six setiferous punctures at posterior margin, otherwise impunctate; tergite VII with coarse non-setiferous punctation in posterior half, impunctate in anterior half, posterior margin with palisade fringe; tergite VIII with dense and distinct granulose non-setiferous punctation, posterior margin with eight crenulae.

$\sigma^{\star}$ : median lobe of aedeagus $0.55 \mathrm{~mm}$ long and shaped as in Figs 153-154, at base of ventral process with a pair of pronounced laminae.

Comparative notes: This species is distinguished from its congeners $P$. setifer CAMERON, 1939 (South India), P. adesi (PACE, 1998) (Hong Kong), and P. bursatus Assing, 2017 (South India) by the shape of the aedeagus, sparser and finer punctation of the elytra, and more slender antennae. For illustrations of $P$. setifer, $P$. bursatus, and $P$ adesi see Assing (2017a) and PACE (1998), respectively.

Distribution and natural history: The type locality is situated in West Yunnan, China. The holotype was sifted from litter in a secondary forest at an altitude of $1750 \mathrm{~m}$.

\subsection{Genus Tetrabothrus BernHAUER, 1915}

Tetrabothrus currently includes 30 species distributed in the southern East Palaearctic, Oriental, and Australian region. A checklist was provided by Assing (2017a).

\section{Tetrabothrus clavatus BeRnHAUER, 1915}

Material examined: China: 1 , Yunnan, Tongbiguan, $24^{\circ} 37^{\prime} \mathrm{N}, 97^{\circ} 39^{\prime} \mathrm{E}, 1340 \mathrm{~m}$, at light in village near river, 24-26.VI.2016, leg. Hájek \& Růžička (NMP).
This species is one of the most widespread representatives of the genus. In China, it had been recorded from various provinces, but not from Yunnan.

\section{Tetrabothrus inflexus Assing, 2015}

Material examined: China: $1 \sigma^{\star}$, Yunnan, $6 \mathrm{~km}$ SSW Tengchong, Rehai Hot Springs, $24^{\circ} 57^{\prime} \mathrm{N}, 98^{\circ} 27^{\prime} \mathrm{E}, 1450 \mathrm{~m}$, orchard margin, sifted under bamboo, 22.VI.2016, leg. Hájek \& Růžička (NMP).

The distribution ranges from Northeast India across China to Thailand and Laos (Assing 2017a).

\subsection{Genus Zyras Stephens, 1835, subgenus Zyras}

The nominal subgenus of the speciose genus Zyras was previously represented in the Palaearctic and Oriental regions by a total of 122 species (Assing 2017c). It was recently revised in three instalments (Assing 2016a, $2017 b, c)$. A comprehensive catalogue of the species recorded from the Palaearctic and Oriental regions was provided by Assing (2017c).

\section{Zyras (Zyras) geminus (KRAATz, 1859)}

Material examined: India: 2 exs., Assam, Bhalukpong, $27^{\circ} 01^{\prime} \mathrm{N}, 92^{\circ} 39^{\prime} \mathrm{E}, 150 \mathrm{~m}, 1-8 . \mathrm{V} .2012$, leg. Šauša (MMB, cAss). China: 1 ex., Yunnan, Tongbiguan, $24^{\circ} 37^{\prime} \mathrm{N}$, $97^{\circ} 39^{\prime} \mathrm{E}, 1340 \mathrm{~m}$, at light in village near river, 24-26. VI.2016, leg. Hájek \& Růžička (NMP). Thailand: 3 exs., Yala Prov., Betong, Gunung Cang Dun vill., III-IV.1993, leg. Horák (MMB).

This species is one of the most widespread and common representatives of the subgenus. For a distribution map see Assing (2017b).

\section{Zyras (Zyras) proximus CAMERon, 1939}

Material examined: India: 4 exs., Arunachal Pradesh, Etalin env., 28 $37^{\prime} \mathrm{N}, 9^{\circ} 53^{\prime} \mathrm{E}, 700 \mathrm{~m}, 12-25$. V.2012, leg. Šauša (MMB, cAss).

The distribution of this widespread species ranges from India across South China to Thailand and Laos (Assing 2017c).

\section{Zyras (Zyras) castaneus (Motschulsky, 1861}

Material examined: Malaysia: 1 오 Pahang, Cameron Highlands, Kampung Kuala Boh vill. env., $4^{\circ} 27^{\prime} \mathrm{N}$, 
$101^{\circ} 34^{\prime}$ E, 850-1050 m, 26.III.-3.IV.2001, leg. Hergovits (MMB). Cambodia: 1 ㅇ, Sihanoukville, 5 m, I.2009, leg. Murzin (MNB).

The above specimen from Cambodia represents a new country record.

\section{Zyras (Zyras) bettotanus CAMERON, 1930}

Material examined: China: Yunnan: 2 exs., Xishuangbanna, $23 \mathrm{~km} \mathrm{NW}$ Jinghong, $\mathrm{Na}$ Ban, $22^{\circ} 10^{\prime} \mathrm{N}, 100^{\circ} 40^{\prime} \mathrm{E}$, 730 m, malaise trap, 30.X.2008, leg. Weigel (NME, cAss) Malaysia: 1 ㅇ, Pahang, Cameron Highlands, Kampung Kuala Boh vill. env., $4^{\circ} 27^{\prime} \mathrm{N}, 101^{\circ} 34^{\prime} \mathrm{E}, 850-1050 \mathrm{~m}$, 26.III.-3.IV.2001, leg. Hergovits (MMB).

Zyras bettotanus is widespread from the Chinese province Yunnan to Malaysia, Java, and Borneo (Assing 2017c).

\section{Zyras (Zyras) conlectus spec. nov.}

urn:Isid:zoobank.org:act:EEF29D05-2E17-4205-805A-B8BFFAE0FE98 (Figs 68-69, 155-157, 166-169)

Type material: Holotype $\sigma^{*}$ : "NW MYANMAR: Chin State, NW Falam, 400-500 m, V.-VI.2016, leg. local collectors / Holotypus o Zyras conlectus sp. n., det. V. Assing 2018" (MNB). Paratypes: 7 exs.: same data as holotype (MNB, cAss).

Etymology: The specific epithet (Latin, adjective: narrow) alludes to the shape of the ventral process of the aedeagus.

Description: Body length $4.5-7.0 \mathrm{~mm}$; length of forebody $2.5-3.0 \mathrm{~mm}$. Habitus as in Fig. 68. Coloration: head and pronotum black; elytra reddish-yellow with the postero-lateral portions extensively blackish; abdomen bicoloured, with segments II-VI reddish and segments VII-VIII blackish-brown to blackish; legs pale-yellowish; antennae blackish-brown to black with antennomeres I brown and II and the base of III yellowish-brown; maxillary palpi dark-brown, with the terminal palpomere yellowish.

Head moderately transverse, broadly impunctate along middle; punctation in lateral dorsal portions moderately coarse and sparse. Eyes large, much longer than postocular region in dorsal view. Antenna 1.9-2.3 mm long; antennomeres IV and V weakly oblong, VI approximately as long as broad or weakly oblong, VII approximately as long as broad or weakly transverse, VIII-X weakly transverse, $\mathrm{X}$ distinctly less than 1.5 times as broad as long, and XI elongate, approximately as long as the combined length of VIII-X.

Pronotum 1.1-1.2 times as broad as long and 1.071.15 times as broad as head, broadest near anterior angles, distinctly tapering posteriad; lateral margins straight in posterior two-thirds (dorsal view); puncta- tion very coarse, very irregularly distributed, arranged in more or less distinct clusters, these clusters often situated in very shallow impressions, middle and lateral portions with extensive impunctate patches.

Elytra $0.75-0.90$ times as long as pronotum; punctation coarse, defined, very dense anteriorly, decreasing in density posteriad, and very sparse near posterior margin. Hind wings fully developed. Metatarsomere I shorter than the combined length of II-IV.

Abdomen with moderately deep anterior impressions on tergites III-V; anterior impressions of tergites III-V and anterior portions of tergites VI-VII each with a transverse band of dense and coarse non-setiferous punctation not arranged in transverse series; tergite III with a lateral setiferous puncture on either side and with four setiferous punctures at posterior margin; tergites IV-V with a lateral setiferous puncture on either side (often accompanied by few non-setiferous punctures) and with four to six setiferous punctures at posterior margin; tergite VI with a lateral setiferous puncture on either side (often accompanied by few non-setiferous punctures) and with six setiferous punctures at posterior margin; tergite VII (Fig. 69) with several irregularly distributed setiferous punctures in posterior portion and with numerous minute setiferous punctures at posterior margin, palisade fringe present; tergite VIII (Fig. 69) with sparse setiferous punctures postero-laterally, posterior margin with sexual dimorphism.

$o^{\star}$ : posterior margin of tergite VIII (Figs 69, 166) with four tooth-shaped projections; posterior margin of sternite VIII convex, nearly truncate in the middle (Fig. 167); median lobe of aedeagus (Figs 155-156) $0.70-0.75 \mathrm{~mm}$ long, with slender and apically acute ventral process and with very short crista apicalis; paramere (Fig. 157) $0.8-0.9 \mathrm{~mm}$ long and with moderately long apical lobe.

ㅇ: posterior margin of tergite VIII smoothly convex or with shallow median concavity (Fig. 168); posterior margin of sternite VIII concave in the middle (Fig. 169).

Comparative notes: As can be inferred from the generally similar external characters, particularly the conspicuously irregular punctation and the unusally uneven surface of the pronotum, and the punctation pattern of the abdomen, as well as from the similar modifications of the male tergite VIII, and from the shape of the apical lobe of the paramere, $Z$. conlectus is closely allied to Z. proximus Cameron, 1939 (India, China, Thailand, Laos) and Z. novinversus Assing, 2017 (Thailand, Laos). It is distinguished from both by the longer, more slender, and apically more acute ventral process of the aedeagus and additionally as follows:

from $Z$. proximus by completely different coloration of the abdomen alone (Z. proximus: abdomen dark-brown with the posterior margins of the segments paler);

from the similarly coloured $Z$. novinversus by darker maxillary palpi and abdominal segments VII-VIII (Z. novinversus: maxillary palpi yellowish to reddish- 
yellow; abdominal segments VII and VIII pale-brown to dark-brown), the elytral punctation ( $Z$. novinversus: elytral punctation less dense anteriorly and not distinctly decreasing in density posteriad), more extensive nonsetiferous punctation of the anterior impressions and anterior portions of tergites III-VI, and by more pronounced teeth at the posterior margin of the male tergite VII.

For illustrations of $Z$. proximus and $Z$. novinversus see Assing (2017b).

Distribution: The type locality is situated to the northwest of Falam in Northwest Myanmar. Additional data are not available.

\section{Zyras (Zyras) pindarae (CHAMPION, 1921)}

Material examined: Nepal: 1 ex., Mahakali/Darchula, Godhani to Jatra to forest SW Thaisain, $29^{\circ} 50^{\prime} \mathrm{N}, 80^{\circ} 41^{\prime} \mathrm{E}$, 1920-2910 m, 18.VI.2017, leg. Kopetz (NME); 2 exs., Mahakali/Darchula, Sitaula env., Kopu Lekh Kulanga Khola, $29^{\circ} 53^{\prime} \mathrm{N}, 80^{\circ} 45^{\prime} \mathrm{E}, 3500 \mathrm{~m}$, at light, 21.VI.2017, leg. Kopetz (NME, cAss); 1 ex., Mahakali/Darchula, Sintol env., $29^{\circ} 50^{\prime} \mathrm{N}, 80^{\circ} 49^{\prime} \mathrm{E}, 3050 \mathrm{~m}$, forest, 26.VI.2017, leg. Kopetz (NME); 1 ex., Kathmandu, S-slope of Mt. Shivapuri, $27^{\circ} 49^{\prime} \mathrm{N}, 85^{\circ} 23^{\prime} \mathrm{E}, 2400-2500 \mathrm{~m}, 2 . \mathrm{VI} .2016$, leg. Schmidt (cAss).

Zyras pindarae has been reported from North India and Nepal (Assing 2017c).

\section{Zyras (Zyras) condignus LAST, 1969}

Material examined: India: 1 , , Uttarakhand Rishikesh, Ganga river, $30.11^{\circ} \mathrm{N}, 78.31^{\circ} \mathrm{E}, 12-13 . I V .2012$, leg. Tomkovich (cAss).

The known distribution is confined to North India and Nepal (Assing 2017c).

\section{Zyras (Zyras) morulus Assing, 2017}

Material examined: Nepal: 4 exs., Mahakali/Darchula, Thaisain env., Brum lake, $29^{\circ} 52^{\prime} \mathrm{N}, 80^{\circ} 41^{\prime} \mathrm{E}, 3600 \mathrm{~m}$, 19-20.VI.2017, leg. Kopetz \& Weigel (NME, cAss); 1 ㅇ, Mahakali/Darchula, Thaisain env., $29^{\circ} 53^{\prime} \mathrm{N}, 80^{\circ} 44^{\prime} \mathrm{E}$, $3860 \mathrm{~m}$, stone debris and alpine mats, 21.VI.2017, leg. Kopetz (NME).

The previously known distribution was confined to the Dhaulagiri and Annpurna ranges in Central Nepal (Assing 2017b). The above records expand the range of this high-altitude species towards the west.

\section{Zyras (Zyras) perforatus (CHAMPION, 1921)}

Material examined: Nepal: 1 ex., Mahakali/Darchula, Godhani to Jatra to forest SW Thaisain, $29^{\circ} 50^{\prime} \mathrm{N}, 80^{\circ} 41^{\prime} \mathrm{E}$ to $29^{\circ} 52^{\prime} \mathrm{N}, 80^{\circ} 40^{\prime} \mathrm{E}, 1920-2910 \mathrm{~m}, 18 . \mathrm{VI} .2017$, leg. Weigel (NME); 1 ex., Mahakali/Darchula, Deuli env., $29^{\circ} 49^{\prime} \mathrm{N}, 80^{\circ} 47^{\prime} \mathrm{E}, 2400 \mathrm{~m}, 27-29 . V I .2017$, leg. Weigel (cAss).

Zyras perforatus has been recorded only from North India and Nepal (Assing 2017b).

\section{Zyras (Zyras) truncatus Assing, 2017}

Material examined: Nepal: $1 \sigma^{*}$, Kathmandu, S-slope of Mt. Shivapuri, $27^{\circ} 49^{\prime} \mathrm{N}, 85^{\circ} 23^{\prime} \mathrm{E}, 2400-2500$ m, 2.VI.2016, leg. Schmidt (NME).

The previously known distribution was confined to the Dhaulagiri range in Nepal (Assing 2017b).

\section{Zyras (Zyras) granapicalis Assing, 2016}

Material examined: China: Sichuan: $10^{*}, 1$ 우 , road $56 \mathrm{~km}$ E Xichang-Zhaojue, Wen Lin pass, $27^{\circ} 52^{\prime} \mathrm{N}, 102^{\circ} 30^{\prime} \mathrm{E}$, 3200 m, 5-20.VI.2017, leg. Reuter (cFel, cAss).

This species has been reported only from the Chinese province Sichuan (Assing 2016a).

\section{Zyras (Zyras) athetoides Assing, 2016}

Material examined: China: Tibet: $10^{\top}, 130 \mathrm{~km}$ E Lhassa, $29^{\circ} 42^{\prime} \mathrm{N}, 92^{\circ} 11^{\prime} \mathrm{E}, 4350 \mathrm{~m}, 25 . \mathrm{VI} .2005$, leg. Rieger (cAss).

The previously known distribution was confined to several localities in Sichuan (Assing 2016a).

\section{Zyras (Zyras) nigricornis Assing, 2016}

Material examined: China: Sichuan: 19 , Daxue Shan, 25 km SE Kangding, 3200-3500 m, 13.VI.-4.VII.2009, leg. Plutenko (MNB).

Zyras nigricornis is widespread in China (Assing 2016a).

\section{Zyras (Zyras) exspoliatus Assing, 2016}

Material examined: China: Yunnan: 1 ㅇ, Xishuangbanna, $37 \mathrm{~km}$ NW Jinghong, Guo Men Shan env., $22^{\circ} 14^{\prime} \mathrm{N}$, $100^{\circ} 36^{\prime} \mathrm{E}, 1080 \mathrm{~m}$, open land, pitfall trap, 10.X.2008, leg. Meng (NME). 
The above material represents the first record since the original description, which is based on a unique male from Diding in Guangxi province (Assing 2016a).

\section{Zyras (Zyras) beijingensis PACE, 1993}

Material examined: China: Hebei: 1 ex., Wulingshan, Longtan Scenic Spot, $40^{\circ} 36^{\prime} \mathrm{N}, 117^{\circ} 27^{\prime} \mathrm{E}, 8 . \mathrm{VIII} .2016$, leg. kment (NMP).

This species is widespread in China, but was previously unknown from Hebei (Assing 2016a).

\section{Zyras (Zyras) wei PACE, 1993}

Material examined: China: Yunnan: 1 \% Xishuangbanna, $23 \mathrm{~km}$ NW Jinghong, Na Ban, $22^{\circ} 10^{\prime} \mathrm{N}, 100^{\circ} 40^{\prime} \mathrm{E}$, $730 \mathrm{~m}$, malaise trap, 30.X.2008, leg. Weigel (NME).

Zyras wei is widespread in China, Laos, and Vietnam, but was previously unknown from Yunnan (Assing 2016a, 2017c).

\section{Zyras (Zyras) hetzeli spec. nov.}

\section{urn:Isid:zoobank.org:act:F00342B5-F2BF-461A-A84A-282D19159065}

(Figs 70, 158-159)

Type material: Holotype o": "TAIWAN, Nantou, Lu-Shan Hot Spring, 1342 m, Conif. forest, litter sifted, $24^{\circ} 01^{\prime} 19^{\prime \prime} \mathrm{N}$, $121^{\circ} 11^{\prime} 45 " E, 25 . V I I .2018$, Hetzel leg. / Holotypus ơ Zyras hetzeli sp. n., det. V. Assing 2018" (cAss).

Etymology: This species is dedicated to Andreas Hetzel, Hildesheim, who collected the holotype.

Description: Body length $6.4 \mathrm{~mm}$; length of forebody $2.4 \mathrm{~mm}$. Habitus as in Fig. 70. Coloration: body black with the posterior margins of the abdominal segments slightly paler; legs pale-yellow; antennae black with antennomeres I-II dark-brown; maxillary palpi dark-brown with the apical palpomere yellow.

Antenna relatively short and fine, $1.8 \mathrm{~mm}$ long; antennomeres IV weakly transverse, V-VIII of gradually increasing width and increasingly transverse, VIII-X barely 1.5 times as broad as long, and XI approximately as long as the combined length of IX and X.

Elytra with punctation somewhat unevenly distributed, posteriorly distinctly sparser (and with impunctate patches) than anteriorly. Other external characters as in Z. wei.

$0^{*}$ : tergite VIII with posterior margin somewhat produced and in the middle weakly concave; sternite VIII strongly convex posteriorly; median lobe of aedeagus $0.68 \mathrm{~mm}$ long and shaped as in Figs 158-159; paramere $0.84 \mathrm{~mm}$ long, apical lobe moderately long and slender, not distinctly modified.

o: unknown.

Comparative notes: In habitus, many other external characters, and even in the shape of the aedeagus, this species is similar to the widespread and variable $Z$. wei. It is distinguished, however, by much less massive and shorter antennae, less dense and unevenly distributed elytral punctation, a strongly convex posterior margin of the male sternite VIII (Z. wei: posterior margin nearly truncate in the middle), and by a smaller median lobe of the aedeagus ( $Z$. wei: median lobe $0.75-0.80 \mathrm{~mm}$ long). The new species is readily separated from other consubgeners recorded from Taiwan by the practically uniformly blackish coloration of the body and antennae alone. For illustrations of other Taiwanese representatives of Zyras sensu strictu see Assing (2016a, 2017c).

Distribution: The type locality is situated in Nantou province, Taiwan. The holotype was sifted from litter in a coniferous forest at an altitude of approximately $1340 \mathrm{~m}$.

\section{Zyras (Zyras) bryanti CAMERon, 1943}

Material examined: Philippines: Mindanao: $1 \%$, Mt. Hamiguitan Wildlife Sanctuary. Banakon creek, $6.74^{\circ} \mathrm{N}$, $126.15^{\circ} \mathrm{E}, 400 \mathrm{~m}$, wet litter and debris sifted, $22-24$. III.2018, leg. Shavrin (cAss); $10^{7}, 3$ 우, Sitio Bitaugan, Kawa-kawa River, 300 m, $6^{\circ} 46^{\prime} 31^{\prime \prime N}, 126^{\circ} 08^{\prime} 41^{\prime \prime E}$, stream bank, wet litter, debris, dead wood, 24-26.III.2018, leg. Shavrin (cAss).

This species is widespread, but rarely recorded in the Oriental region (Thailand, Peninsular Malaysia, Borneo, Philippines). In the Philippines, it was previously known only from one locality in Luzon (Assing 2017c).

Zyras (Zyras) reductus spec. nov. urn:Isid:zoobank.org:act:15761BF9-31AA-4B92-A7A5-8C3535DF876C (Figs 71-74, 160-162)

Type material: Holotype $0^{\top}:$ "PHILIPPINES: Mindanao, Sitio Bitaugan, Kawa-kawa River, $300 \mathrm{~m}, 6^{\circ} 46^{\prime} 31^{\prime \prime N}$, $126^{\circ} 08^{\prime} 41^{\prime} \mathrm{E}$, stream bank, wet litter, debris, dead wood, 24-26.III.2018, leg. Shavrin / Holotypus ơ Zyras reductus sp. n., det. V. Assing 2018” (cAss).

Etymology: The specific epithet is the past participle of the Latin verb reducere and alludes to the completely reduced hind wings.

Description: Body length $6.2 \mathrm{~mm}$; length of forebody $2.7 \mathrm{~mm}$. Habitus as in Fig. 71. Coloration: forebody brown; abdomen dark-brown with the anterior margins and the 
narrow posterior margins of the segments reddish-yellow and with the postero-median portions of tergites $\mathrm{V}$ and VI blackish; legs yellowish; antennae pale reddish-brown with antennomere XI dark-yellowish and the basal three antennomeres pale-reddish; maxillary palpi yellow.

Head (Fig. 72) 1.1 times as broad as long; punctation sparse and very shallow, median portion extensively impunctate. Eyes strongly convex, longer than postocular region in dorsal view. Antenna (Fig. 73) $2.2 \mathrm{~mm}$ long and rather slender; antennomeres IV-V weakly oblong, VI approximately as long as broad, VII-X weakly oblong, X much less than 1.5 times as broad as long, and $\mathrm{XI}$ approximately as long as the combined length of IX and $\mathrm{X}$.

Pronotum (Fig. 72) approximately as broad as long and 1.07 times as broad as head, broadest at anterior angles, rather strongly convex in cross-section; lateral margins not sinuate in dorsal view; posterior angles obtusely marked; punctation rather coarse, moderately sparse, and somewhat irregularly distributed; impunctate median band moderately broad.

Elytra (Fig. 72) conspicuously short, 0.55 times as long as pronotum, distinctly dilated posteriad; humeral angles completely obsolete; punctation moderately dense, very coarse, and sharply defined. Hind wings completely reduced. Legs long and slender; metatarsomere I slender, nearly as long as the combined length of II-IV.

Abdomen (Fig. 74) distinctly broader than elytra, with rather deep anterior impressions on tergites III-V; anterior impressions of tergites III-V each with a transverse row of distinct non-setiferous punctures, with few lateral setiferous punctures on either side, and with six (tergites III and IV) or eight (tergite V) setiferous punctures bearing long black setae at or near posterior margin; tergite VI with a transverse row of non-setiferous punctures anteriorly, with few lateral setiferous punctures on either side and with ten setiferous punctures at or near posterior margin; tergite VII with a transverse band of rather sparse non-setiferous punctures anteriorly and with two highly irregular transverse series of setiferous punctures posteriorly, posterior margin with an indistinct rudiment of a palisade fringe; tergite VIII with setiferous punctation only in posterior third, posterior margin strongly convex.

$o^{\star}$ : sternite VIII strongly produced posteriorly, posterior margin truncate in the middle; median lobe of aedeagus approximately $0.75 \mathrm{~mm}$ long and shaped as in Figs 160-161; paramere (Fig. 162) $0.9 \mathrm{~mm}$ long, apical lobe rather short, flattened and apically broadly convex.

†: unknown.

Comparative notes: Based on the slender habitus, the slender antennae, the strongly convex pronotum (crosssection), the punctation pattern of the abdomen, and the morphology of the aedeagus (shape of median lobe and of apical lobe of paramere), this conspicuous species is closely related to Z. nitens CAMEron, 1944, Z. glabricol- lis Scheerpeltz, 1965, Z. truncatus Assing, 2017, and allied species. It is readily distinguished from all other species of Zyras sensu strictu by much shorter elytra alone. The only other species that is at least close to this condition is Z. kinabaluensis Pace, 2008 from Borneo, from which $Z$. reductus is distinguished by even shorter elytra (Z. kinabaluensis: elytra 0.65 times as long as pronotum), larger body size (Z. kinabaluensis: length of forebody $2.4 \mathrm{~mm}$ ), less slender antennae with a longer antennomere XI, larger and more convex eyes, a broader abdomen, and by the shape of the aedeagus. For illustrations of Z. kinabaluensis see Assing (2017c) and PACE (2008).

Distribution: The type locality is situated in Davao Oriental Province in the southeast of Mindanao, South Philippines. The holotype was collected by sifting wet litter between stones, wet debris, and dead wood accumulated near the Kawa-kawa river at an altitude of $300 \mathrm{~m}$.

\section{Zyras (Zyras) shavrini spec. nov. urn:Isid:zoobank.org:act:A7C7B14F-AA8A-47EB-AA6F-F7A7C2B040A4 (Figs 75-78, 163-165)}

Type material: Holotype ơ [slightly teneral]: "PHILIPPINES: Mindanao, Barangay Baganihan, Marilog D., Eagles Ridge, $7^{\circ} 45^{\prime} \mathrm{N}, 125^{\circ} 23^{\prime} \mathrm{E}$, secondary forest, wet litter sifted, 26-28.III.2018, leg. Shavrin / Holotypus o Zyras shavrini sp. n., det. V. Assing 2018” (cAss).

Etymology: This species is dedicated to Alexey Shavrin (Daugavpils), specialist of Omaliinae (Staphylinidae), who collected the holotype.

Description: Rather larger species: body length $8.2 \mathrm{~mm}$; length of forebody $3.7 \mathrm{~mm}$. Habitus as in Fig. 75. Coloration: body pale-reddish, except for the slightly infuscate median portion of tergite VI; legs yellow; antennae with antennomeres I-II reddish, III-IV brown, V yellowishbrown, and VI-XI pale-yellowish; maxillary palpi pale-reddish.

Head (Fig. 76) 1.22 times as broad as long; punctation moderately coarse and dense, median portion impunctate. Eyes large, approximately twice as long as postocular region in dorsal view. Antenna (Fig. 77) $2.5 \mathrm{~mm}$ long; antennomere IV weakly transverse; antennomeres V-X transverse, of gradually increasing width, and increasingly transverse, $\mathrm{X}$ slightly less than twice as broad as long, and XI of conical shape, shorter than the combined length of IX and X.

Pronotum (Fig. 76) approximately 1.1 times as broad as long and 1.2 times as broad as head, broadest near anterior angles, weakly convex in cross-section; lateral margins very weakly sinuate in posterior two-thirds in dorsal view; posterior angles obtusely marked; punctation relatively fine and very dense; impunctate median 
band narrow; pubescence long, black, and suberect; near lateral and anterior margins with numerous long black and erect setae.

Elytra (Fig. 76) 0.8 times as long as pronotum; punctation rather fine and very dense; pubescence long, black, and suberect. Hind wings fully developed. Legs moderately long and slender; metatarsomere I nearly as long as the combined length of II-IV.

Abdomen (Fig. 78) broad, slightly narrower than elytra, and somewhat wedge-shaped; with rather deep anterior impressions on tergites III-V; all sternites and paratergites with long, dense, and suberect to erect pubescence; anterior impressions of tergites III-V each with a transverse row of non-setiferous punctures, with two transverse series of setiferous punctures in posterior portion, and with scattered micropunctation; tergite VI with a transverse band of dense non-setiferous punctures anteriorly, with sparse non-setiferous punctures across the middle, and with setiferous punctures near posterior margin and postero-laterally; tergite VII with a broad transverse band of dense non-setiferous punctures anteriorly and with setiferous punctures in posterior half, this setiferous punctation much denser in postero-lateral portions than in the middle, posterior margin with palisade fringe; tergite VIII with rather dense setiferous punctation in posterior half, posterior margin broadly convex.

$0^{\top}$ : posterior margin convex, in the middle nearly truncate; median lobe of aedeagus approximately $0.9 \mathrm{~mm}$ long and shaped as in Figs 163-164, ventral process apically long and acute; paramere (Fig. 165) $1.05 \mathrm{~mm}$ long and with short apical lobe.

q: unknown.

Comparative notes: As can be inferred from the long and dense pubescence of the whole body, the morphology of the antennae (antennomere XI short and of conical shape), the robust habitus with a broad and wedge-shaped abdomen, the long and dense pale pubescence of the abdomen, and the morphology of the aedeagus (shape of the ventral process; apical lobe of the paramere very short), $Z$. shavrini belongs to the $Z$. hirtus group. The new species is distinguished from other similarly coloured species of this group by the shape of the median lobe of the aedeagus (particularly the long and acute apex of the ventral process), by the conspicuously dense punctation of the forebody, and additionally as follows:

from Z. hirtus (KraAtZ, 1859) (South India, Sri Lanka) by slightly larger size, the coloration of the antennae, and the blackish pubescence of the forebody;

from Z. titan Assing, 2017 (Sulawesi; largest species of the subgenus), by smaller size, the coloration of the antennae, a more transverse pronotum, blackish pubescence of the forebody, shorter and less slender legs, by the punctation pattern of the abdomen ( $Z$. titan: setiferous punctures much sparser), and by the shape of the male tergite VIII; from Z. matangensis CAMERoN, 1943 (Borneo) by larger size, the coloration of the antennae, a more transverse pronotum, and a broader, more distinctly wedge-shaped abdomen with denser setiferous punctation, and with distinct non-setiferous punctation in the anterior impressions of tergite III-V (absent in Z. matangensis);

from Z. lunatus Assing, 2017 (Peninsular Malaysia) by a larger and more robust body, the coloration of the antennae, a more transverse pronotum, and an abdomen with distinct non-setiferous punctation in the anterior impressions of tergites III-V, with coarser nonsetiferous punctation on the remaining tergites, and with denser setiferous punctation;

from Z. parahirtus Assing, 2017 (Borneo) by paler coloration, a larger and more robust body, the coloration of the abdomen, a less convex (cross-section) and more transverse pronotum, the presence of non-setiferous punctation in the anterior impressions of tergites III-V (indistinct in Z.parahirtus), and by denser setiferous punctation of the abdomen;

from Z. flavorufus CAMERon, 1939 by larger body size, the coloration of the antennae, a less convex pronotum (cross-section), and an abdomen with distinct non-setiferous punctation in the anterior impressions of tergites III-V and with much denser setiferous punctation.

For illustrations and detailed descriptions of Z. hirtus, Z. titan, Z. matangensis, Z.lunatus, Z. parahirtus, and Z. flavorufus see Assing (2016a, 2017b, c).

Distribution: The type locality is situated in Central Mindanao, South Philippines. The slightly teneral holotype was sifted from wet litter near small rocks in a secondary broad-leaved forest.

\subsection{Genus Pedinopleurus Cameron, 1939}

\section{Pedinopleurus notabilis (SILVESTRI, 1946)}

Material examined: China: 1 ex., Yunnan, Xishuangbanna, $23 \mathrm{~km} \mathrm{NW}$ Jinghong, $\mathrm{Na} B a n, 22^{\circ} 10^{\prime} \mathrm{N}, 100^{\circ} 40^{\prime} \mathrm{E}$, $680 \mathrm{~m}$, light trap, 17.V.2008, leg. Weigel (NME); 1 ex., Xishuangbanna, $25 \mathrm{~km}$ NW Jinghong, Zhong Zhi Chang, $22^{\circ} 11^{\prime} \mathrm{N}, 100^{\circ} 39^{\prime} \mathrm{E}, 780 \mathrm{~m}$, rubber plantation, malaise trap, 20.X.2008, leg. Weigel (cAss); 1 ex., Xishuangbanna, $60 \mathrm{~km} \mathrm{~N}$ Jinghong, Guanping env., $1000 \mathrm{~m}$, 19-27.I.2003, leg. Murzin (cAss); 2 exs., Yunnan, Tongbiguan, $24^{\circ} 37^{\prime} \mathrm{N}, 97^{\circ} 39^{\prime} \mathrm{E}, 1340 \mathrm{~m}$, at light in village near river, 24-26.VI.2016, leg. Hájek \& Růžička (NMP, cAss). Laos: 1 ex., 5 km SW Muang Sing, Chiang Tung (stupa), $750 \mathrm{~m}, 26 . I I I .-5 . I V .2010$, leg. Murzin (MNB); 2 exs., Hua Phan province, Mt. Phu Pane, $20^{\circ} 12^{\prime} \mathrm{N}, 103^{\circ} 59^{\prime} \mathrm{E}$, 1200-1900 m, 10-21.VI.2010, leg. Jakl \& local collectors (MNB, cAss). 
The currently known distribution includes South China, Vietnam, and Laos. The species was recently reported from China (Yunnan) for the first time (Assing 2016b).

\section{Acknowledgements}

The colleagues listed in the material section kindly arranged loans of specimens. In particular, I am grateful to Alexey Shavrin (Daugavpils) for the generous gift of most interesting Lomechusini (including several holotypes) from the Philippines, as well as to Benedikt Feldmann (Münster) and Guillaume de Rougemont (Oxford) for the permission to retain the holotypes of Pella feldmanni, Zyras hetzeli, and Orphnebius moruliflavus, respectively. Benedikt Feldmann proof-read the manuscript.

\section{References}

Assing, V. 2003: A review of the Himalayan species of Amaurodera (Coleoptera: Staphylinidae: Aleocharinae). - Entomological Problems 33: 5-20.

Assing, V. 2006: A new species and new records of Amaurodera FAuvel from Nepal (Coleoptera: Staphylinidae, Aleocharini). - Beiträge zur Entomologie, Keltern 56 (1): 155-160. - https://www.contributionsto-entomology.org/article/view/1658/1657.

Assing, V. 2008: Three new species of Pella Stephens from Turkey and Iraq, with a checklist of the species recorded from Turkey (Coleoptera: Staphylinidae: Aleocharinae: Lomechusini). - Linzer Biologische Beiträge 40 (1): 235-243. - https://www.zobodat.at/ publikation_volumes.php?id $=26687$.

Assing, V. 2009: New species and additional records of Lomechusini from the Palaearctic region (Coleoptera: Staphylinidae: Aleocharinae). - Stuttgarter Beiträge zur Naturkunde Serie A, Neue Serie 2: 201-226. - https:// www.naturkundemuseum-bw.de/sites/default/files/ publikationen/serie-a/ans02-05assinglomechusini.pdf.

Assing, V. 2015a: On the Orphnebius fauna of the East Palaearctic region. VI. Six new species from China and Taiwan, and additional records (Coleoptera: Staphylinidae: Aleocharinae: Lomechusini). - Linzer Biologische Beiträge 47 (1): 101-125. - https://www. zobodat.at/pdf/LBB_0047_1_0101-0125.pdf.

Assing, V. 2015b: New species and additional records of Lomechusini from the Palaearctic region, primarily from China (Coleoptera: Staphylinidae: Aleocharinae). - Contributions to Entomology 65 (2): 243-262. - https://www.contributions-toentomology.org/article/view/1882/1881.

Assing, V. 2015c: On the Lomechusini fauna of Vietnam (Coleoptera: Staphylinidae: Staphylininae). - Linzer Biologische Beiträge 47 (2): 1257-1282. - https:// www.zobodat.at/pdf/LBB_0047_2_1257-1282.pdf.
Assing, V. 2016a: A revision of Zyras Stephens sensu strictu of China, Taiwan, and Hong Kong, with records and (re-)descriptions of some species from other regions (Coleoptera: Staphylinidae: Aleocharinae: Lomechusini). - Stuttgarter Beiträge zur Naturkunde A, Neue Serie 9: 87-175. - https://www. zobodat.at/pdf/Stuttgarter-Beitraege-Naturkunde_ NS_9_A_0087-0175.pdf.

Assing, V. 2016b: On some Lomechusini of the Palaearctic and Oriental regions (Coleoptera: Staphylinidae: Aleocharinae). - Contributions to Entomology 66 (1): 13-111. - https://www.contributions-to-entomology. org/article/view/1893/1892.

Assing, V. 2016c: On the Staphylinidae of the Greek island Lesbos II, with supplementary notes on the fauna of Samos and Chios (Coleoptera: Staphylinidae). - Koleopterologische Rundschau 86: 103-138. - https://www.zobodat.at/pdf/KOR 86_2016_0103-0138.pdf.

Assing, V. 2017a: On the Lomechusini fauna of the East Palaearctic and Oriental regions, with a focus on the genera Orphnebius and Amaurodera (Coleoptera: Staphylinidae: Aleocharinae). - Contributions to Entomology 67 (1): 63-106. - https://www.contributions-to-entomology.org/article/view/ 1918/1915.

Assing, V. 2017b: On Zyras sensu strictu in the East Palaearctic and Oriental regions, with a focus on the faunas of the Himalaya, India, Sri Lanka, Thailand, and Sulawesi (Coleoptera: Staphylinidae: Aleocharinae: Lomechusini). - Contributions to Entomology 67 (1): 117-192. - https://www.contributions-to-entomology.org/article/view/1920/1923.

Assing, V. 2017c: On the Zyras sensu strictu in the East Palaearctic and Oriental regions III, with a focus on the Southeast of Continental Asia and the Sunda Islands (Coleoptera: Staphylinidae: Aleocharinae: Lomechusini). - Contributions to Entomology 67 (2): 213-246. - https://www.contributions-toentomology.org/article/view/1939/1939.

Hlaváč, P.; Newton, A. F. \& Maruyama, M. 2011: World catalogue of the species of the tribe Lomechusini (Staphylinidae: Aleocharinae). - Zootaxa 3075: 1-151. - https://www.mapress.com/zootaxa/2011/1/ zt03075p151.pdf.

IABLOKOFF-KhNZORIAN, S. M. 1962: Novye vidy zhestkokrylykh iz Zakavkazya. New species of Coleoptera from Transcaucasus (Insecta-Coleoptera). - Zoologichesky Sbornik Zoologichesky Institut, Akademii Nauk Armyanskoy SSR 12: 99-124.

Kistner, D. H. 1994: A new species of Drusilla from the Philippines that is predaceous upon Hospitalitermes (Coleoptera: Staphylinidae; Isoptera: Termitidae). Sociobiology 23 [1993] (2): 183-188.

Maruyama, M. 2004: Two new species of Lomechusini (Coleoptera: Staphylinidae: Aleocharinae) from Laos. - Entomological Review of Japan 59(1): 87-97. 
Maruyama, M. 2006: Revision of the Palearctic species of the myrmecophilous genus Pella (Coleoptera, Staphylinidae, Aleocharinae). - National Science Museum Monographs 32: 1-207.

PACE, R. 1987: Aleocharinae dell'Asia sudorientale raccolte da G. de Rougemont (Coleoptera, Staphylinidae). - Bolletino del Museo Civico di Storia Naturale di Verona 13 (1986): 139-237.

PACE, R. 1989: Aleocharinae attere del Monte Kinabalu (Borneo) (Coleoptera, Staphylinidae). - Revue Suisse de Zoologie 96 (1): 3-8. - https://doi.org/10.5962/ bhl.part.82023.

PACE, R. 1998: Aleocharinae della Cina: Parte IV (Coleoptera, Staphylinidae). - Revue Suisse de Zoologie 105 (4): 911-982.

PACE, R. 2000: Aleocharinae della Thailandia (Coleoptera, Staphylinidae). - Bollettino del Museo Regionale di Scienze Naturali, Torino 17 (1): 39-86.

PACE, R. 2004: Aleocharinae di Thailandia, Cambogia, Laos e Malaysia (Coleoptera, Staphylinidae). - Belgian Journal of Entomology 6: 243-302. - http://www. srbe-kbve.be/cm/sites/default/files/publications/ BJE/BJE\%202004/BJE\%202004\%20vol\%206\%20 $\% 282 \% 29 \% 20$ Pace.pdf.

PACE, R. 2008: Generi e specie della tribù Lomechusini del Borneo (Coleoptera, Staphylinidae). - Revue Suisse de Zoologie 115 (1): 107-156.

PACE, R. 2012: Biodiversità delle Aleocharinae della Cina: Lomechusini e Thamiaraeini (Coleoptera, Staphylinidae). - Beiträge zur Entomologie, Keltern 62 (1): 77-102. - https://www.contributions-toentomology.org/article/view/1807/1806.
PACE, R. 2013: New distributional data, new species and three new genera of Aleocharinae from Malaysia, Vietnam and Taiwan (Coleoptera: Staphylinidae). Tropical Zoology 26 (1): 33-63. - https://doi.org/10. 1080/03946975.2013.775832.

PACE, R. 2014: Aleocharinae from Sabah (Borneo) collected by Guillaume de Rougemont (Coleoptera, Staphylinidae). - Linzer Biologische Beiträge 46 (1): 727-794. - https://www.zobodat.at/pdf/LBB_0046 _1_0727-0794.pdf.

Schülke, M. \& Smetana, A. 2015: Staphylinidae, pp. 304-1134. - In: LöBL, I. \& LöBL, D. (eds), Catalogue of Palaearctic Coleoptera. Volume 2. Hydrophiloidea - Staphylinoidea. Revised and updated edition. - Brill, Leiden: xxvi + 1702 pp.

Song, X.-B. \& LI, L.-Z. 2013: Description of Pella maoershanensis sp. n. (Coleoptera, Staphylinidae, Aleocharinae) associated with Lasius spathepus from Guangxi, South China. - ZooKeys 275: 17-21. https://doi.org/10.3897/zookeys.275.4449.

Zheng, D.-L. \& ZhaO, M.-J. 2014: Description of Pella sichuanensis sp.n. (Coleoptera: Staphylinidae: Aleocharinae) from Micang Mountain, Sichuan, China. - Zootaxa 3881 (6): 597-599. - http://dx.doi. org/10.11646/zootaxa.3881.6.9. 